\title{
Het informele huwelijk: de verbondenheid tussen mens, goed en schuld
}

Citation for published version (APA):

Forder, C. J. (2000). Het informele huwelijk: de verbondenheid tussen mens, goed en schuld. Kluwer. https://doi.org/10.26481/spe.20001027cf

Document status and date:

Published: 27/10/2000

DOI:

$10.26481 /$ spe.20001027cf

Document Version:

Publisher's PDF, also known as Version of record

\section{Please check the document version of this publication:}

- A submitted manuscript is the version of the article upon submission and before peer-review. There can be important differences between the submitted version and the official published version of record.

People interested in the research are advised to contact the author for the final version of the publication, or visit the DOI to the publisher's website.

- The final author version and the galley proof are versions of the publication after peer review.

- The final published version features the final layout of the paper including the volume, issue and page numbers.

Link to publication

\footnotetext{
General rights rights.

- You may freely distribute the URL identifying the publication in the public portal. please follow below link for the End User Agreement:

www.umlib.nl/taverne-license

Take down policy

If you believe that this document breaches copyright please contact us at:

repository@maastrichtuniversity.nl

providing details and we will investigate your claim.
}

Copyright and moral rights for the publications made accessible in the public portal are retained by the authors and/or other copyright owners and it is a condition of accessing publications that users recognise and abide by the legal requirements associated with these

- Users may download and print one copy of any publication from the public portal for the purpose of private study or research.

- You may not further distribute the material or use it for any profit-making activity or commercial gain

If the publication is distributed under the terms of Article $25 \mathrm{fa}$ of the Dutch Copyright Act, indicated by the "Taverne" license above, 


\section{Het informele huwelijk:}

de verbondenheid tussen mens, goed en schuld 



\title{
Het informele huwelijk:
}

\section{de verbondenheid tussen mens, goed en schuld}

\author{
REDE UITGESPROKEN \\ BU DE AANVAARDING VAN HET AMBT VAN \\ BIIZOMDER HOOGLERAAR EUROPEAN FAMLY LAW,
}

AAN DE UNIVERSITEIT MAASTRICHT

OP VRIJDAG 27 OKTOBER 2000

DOOR CAROLINE J. FORDER

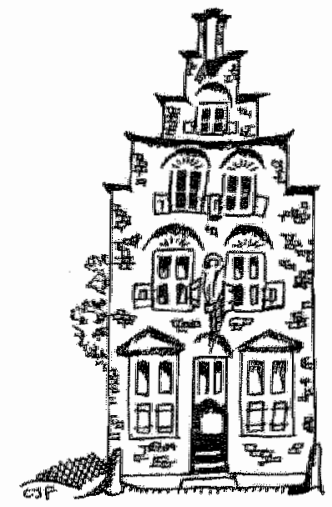

MAASTRICHT

2000 
Met dank aan Jan de Boer, Radsheer in het Hof van Justitie van de Nederlandse Antillen, mijn collega Professor Ton Gehlen, Emeritus Bijzonder Hoogleraar in de Rechtsgeschiedenis aan de Universiteit Maastricht en notaris en Rob Bakker, rechter in de Rechtbank Maastricht, tevens mijn echtgenoot en samenwoner, voor hum nuttige opmerkingen op eerdere conceptem.

Uitgever: Kluwer, Deventer

ISBN 9026837038

(C) 2000, Caroline J. Forder

Lay-out: Margriet van Woerden

Tekening omslag: Caroline Forder

Alle rechten voorbehouden. Niets uit deze uitgave mag worden verveelvoudigd, opgeslagen in cen geautomatiseerd gegevensbestand, of openbaar gemaakt, in enige vorm of op enige wijze, hetzij elektronisch, mechanisch, door fotokopieên, opnamen, of enige andere manier, zonder voorafgaande schriftelijke toestemming van uitgeverij Kluwer.

Voor zover het maken van kopieżn uit deze uitgave is toegestaan op grond van artikel $16 b$ Auteurswet 1912 jo. het Besluit van 20 juni 1974, Stb. 351, zoals gewijzigd bij het Besluit van 23 augustus 1985, Stb. 471, en artikel 17 Auteurswet 1912, dient men de daarvoor verschuldigde wettelijke vergoedingen te voldoen aan de Stichting Reprorecht (Postbus 882, 1180 AW Amstelveen). Woor het overnemen van gedeelte(n) unit deze uitgave in bloemlezingen, readers en andere compilatiewerken (artikel 16 Auteurswet 1912) dient men zich tot de uitgever te wenden. 
Het is mij een eer om $u$ iets over het Europees familierecht te vertellen. I $k$ zal dat doen door een concreet voorbeeld te geven van een matschappelijk probleen in Nederlland dat door rechtswergelijking met andere Europese stelsels kan worden opgehelderd. Europees familierecht heeft betrekking op verdragen, op intemationale rechtspraak en op rechts-vergelijking. Voor het onderwerp dat ik vandaag bespreek is vooral de rechtswergelijking van belang.

Indien mevrouw en mijnheer Bakker zijn getrouwd, is een heel stelsel van huwelijkswermogensrecht van toepassing. In beginsel, tenzij zij iets anders afspreken, vallen al hun goederen in algehele gemeenschap van goederen en hebben zij bij de verdeling beiden recht op de helft. Als zij uit elkaar gaan en mevrouw of mijnheer Bakker niet in staat is in haar of zijn onderhoud te voorzien, heeft zij of hij recht op alimentatie van de ex-partner. En als zij niet uit elkaar gaan en een van hen komt te overlijden, heeft de overlevende echtgenoot een speciale positie in het erfrecht. Maar, als zij niet trouwen, ligt de hele situatie anders. Hier begeven wif ons op het gebied dat aangeduid zou kunnen worden als het informele huwelijk. In principe is er geen gemeenschap van goederen, geen onderhoudsverplichting en geen erfrechtelijke bepaling die van toepassing is op de overlevende samenwoner. Zij zijn vrij om naar de notaris te gaan en een samenlevingsovereenkomst op te laten stellen. ${ }^{1}$ Wat is echter hun rechtspositie als zij dit niet doen? Hierover wil ik het vanmiddag hebben. Ik zal in het bijzonder ingaan op de regelling met betrekking tot de verdeling van de goederen, omdat dit aspect mijns inziens een centrale plaats inneemt. Tegelijk geef ik een cleel van mijn progranma voor de komende jaren prijs, want na deze oratie resten nog talloze problemen met betrekking tot het samenleven: onderhoudsverplichting, erfrechtelijke vragen, maar ook vele vraagstukken buiten het privaatrechtelijke vakgebied, zoals de regeling van samenlevers in het sociale zekerheidsmecht. Ik zal deze middag eerst ingaan op het Nederlandse recht en enkele tekortkomingen hiervan aanduiden. Vervolgens zal ik aan de hand van een aantal buitenlandse uitstapjes laten zien hoe de problemen in Nederland aangepakt zouden kunnen worden. Ik zal vooral de aandacht vestigen op rechtsstelsels die een wettelijke regeling voor samenwoners kennen.

In het Nederlandse privaatrecht zijn slechts enkele aspecten van de relatie tussen ongehuwd samenwonenden wettelijk geregeld. Te denken valt met name aan de wettelijke huurbescherming en verschillende aspecten van het ongehuwd ouderschap. In 1992 heeft de Commissie voor de toetsing van wetgevingsprojecten in haar advies inzake de behandeling van verschillende leefvormen atanbevolen om naast de 'zware' vorm van registratie die uiteindelijk als registratie van partnerschap is ingevoerd, ook een 'lichte' vorm van registratie bij de burgerlijke stand in te voeren. De 'lichte' registratie zou in de privaatrechtelijke sfeer een wederzijdse onderhoudsplicht tussen de geregistreerden tot stand brengen. In de publiekrechtelijke sfeer zou de lichte regi- 
Stratie ertoe leiden dat de geregistreerden als gelhwwen zouden worden behandeld. ${ }^{2}$ Naar aanleiding van een onderzoek nar de werkbaaheid van de voorstellen van de Toetsingscommissie heeft de regering besloten van de lichte registratievorm af te zaten. Gevreesd werd dat de parners het in de publiekrechtelike sfeer te zeer in eigen hand zouden hebben om al dan niet als gehuwd te worden aangemerkt, al naar gelang dat dit voor hen financieel voordeel zou opleveren. ${ }^{3}$ Daarna is er geen discussie meer geweest over de regeling wan de privaatrechtelijke gevolgen van informele relaties. Met betrekking tot de publiekrechtelijke gevolgen zujn de begrippen in de diverse wetten geharmoniseerd. ${ }^{4}$

Dat de regeling van de relatie tussen stamenwonenden aan de partijen wordt overgelaten heef te maken met een aantal overwegingen. Allereerst kan worden gewezen op de verscheidenheid wan de relaties tussen samenwonenden, wat het moellijk maakt om algemeen geldende criteria op te stellen. Er is in dit verband wel eens gesproken van "onoverkomelijke" "praktische moeilijkheden." Een tweede overweging is de relatievtijheid: samenwonenden hebben ervoor gekozen om zich niet aan de regels wan het huwelik te onderwerpen. Een wettelijke regeling zou hun keuze doorkruisen. ${ }^{6}$ Ten slotte neem de regering het standpunt in dat zich in de praktujk gcen problemen voordoen die door de wetgever tot een oplossing zouden moeten worden gebracht. ${ }^{7}$ Daarbij wijst de regering er op dat samenwonenden, indien zij dat wensen, een notariele samenlevingsovereenkomst kunnen opstellen.

De vraag wat er in het recht moet worden geregeld voor ongehuwd samenwonenden die nalaten een samenlevingsovereenkomst te sluiten is actueler dan ooit. Aanvankeljjk was samenwoning in Nederland nog een betrekkelijk weinig woorkomend verschijnsel. Inmiddels is, zoals hierna nog zal blijken, het aantal samenwonenden enom toegenomen, en de voorspellingen zijn dat deze toename nog zal woortduren. Bovendien worden thans veel meer kinderen door ongehuwd samenwonenden opgevoed. Deze kinderen lopen vermoedelijk een groter risico dat hun ouders uit elkar gaan dan kinderen van gehuwden. Het ligt voorts in de lijn der verwachting dat de problemen waarmee de ouders te kampen hebben als zij uit elkaar gaan voor gumenwonenden minstens zo erg zijn als voor gehuwde ouders. Als er geen regeling is getrofien voor het onderhoud en de goederen, is de situatie van de kinderen warschijnlijk slechter dan na een echtscheiding.

De rechtspraak van het Europees Hof voor de Rechten van de Mens werplicht de Lid-staten niet een regeling voor ongehuwd samenwonenden te maken. Zo overwoog het Hof in Johnston t. Kerland: "However, like the Commission, the Court does

3 Actules van do Cominisgie voor de loetsing wan wetgevingsprojecten (Toetingscommissio) inzake

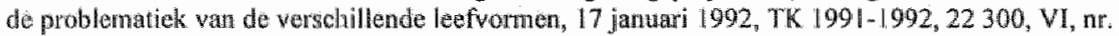
36.

$3 \mathrm{TK}, 1992-1993,22700$, ar. $3, \mathrm{pp}, 8-11$.

4 Zie liet kabinetsigtandpunt van $\| 4$ augustus 1996 met betrekking tot het rapport wan de interdepartementale werkos over harmonisatie van leefvombepalingen in de regetgeving. TK 1995 . 1906,22700, nr. 21. Herbij is voor de wettelijke bepalingen over ongehuwd samenwonenden grotendeels anteasloten bij de destotreffende bepalingen in de op 1 janumi 1996 in werking getreden Algemene bijstandswet en de Algemene nabestandenw ext.

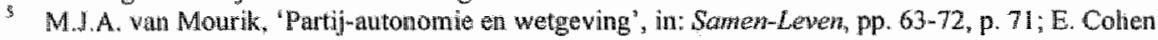
Henriquez, "Regels van samenlevingsoverenkomst", in: Relatiewijhewd en recht, pp. 94-101, p. 96.

5. Bijv. Gr. var dor Burght, "Het wermogensredutelik minimum als uitgangspunt als persorven gaan

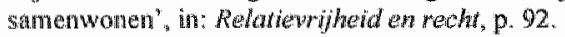

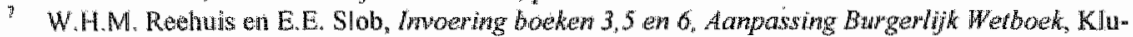
wer, Doventer, 1991, p. 54. 
wot consider it is passible to derve from Article 8 an whigation on we part of lreland to establish for unmarried couples a status anatogows to that of matried coup.

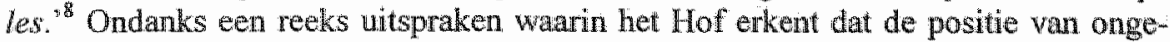
huwd samenwonenden voor wat hun relatie tof de kinderen aangaal dramatisch is veranderd, ziet het er niet naar uit dat het Hof in de nabije toekomst zijn in Johnston witgezette koers zal wijzigen. In een wat verdere toekomst liggen misschien wel veranderingen in het verschiet.

In Petrovic Oostevrijk heef het Europese Hof voor de Rechten van de Mens erkend dat het recht op respect voor het gezinsleven een financiele dimensie heeft. In deze zaak heeft het Hof geoordeeld dat een ouderschapsuitkering van invloed kan zijn op de feitelijke invulling die aan het gezinsleven wordt gegeven en dat deze daarom onder het toepassingsbereik wan artikel 8 EVRM valt. De zaak Petrowic had betrekking op ouderschapsverloven- of uitkeringen die alleen aan de moeder werden toegekend, terwijl de vader van dit recht werd uitgesloten. Naar het oordeel van het Hof was er echter geen sprake van discriminatie. Gelet op de geringe common ground" tussen de Lid-Staten met betrekking tot de toekenming van ouderschapsverloven of -uitkeringen aan vaders, was het Hof van oordeel dat Oostenrijk binnen haar beoordelingsmarge was gebleven door de uitkering uitsluitend aan de moeden toe te kemnen. Als het twaalfde protocol van kracht wordt, ${ }^{11}$ zal het Europese Hof zich meer dan nu het geval is gaan bezighouden met economische en sociale rechten en zal het Hof naar verwachting meer oog krijgen voor nauw met de klassieke grondrechten verbonden sociale en economische rechten. Te denken valt bijwoorbeeld aan een gebrek aan woonruinte, dat ernstige gevolgen kam hebben woor de ouder die het gezag over zijn kind wil krijgen. Zelfs de uitoefening van een omgangstecht zal beperkt zijn indien de ouder over geen of ongeschikte woontuimte beschikt. Zo komen. de economische aspecten in beeld van het grondrecht wan een ouder en kind op ongang met elkaar, dat door artikel $8 \mathrm{EVRM}^{12}$ en artikel 9 lid 3 van het WN kinderverdrag is beschermd. Maar ook mensenrechtelijke bescherming van andere aspecten van een samenwoningsrelatie dan de positie van de samenwoners als ouders is denkbaar. In Canada heeft het Court of Appeal van Nova Scotia geoordeeld dat het ontbreken van de mogeljikheid om na de verbreking van een tienjarige samenleving een rechterlijke uitspraak te verkrijgen over de verdeling van het huis en wan andere tijdens de samenleving verworven goederen, een schending inhoudt wan het Human Rights Charter. Het Hof redeneerde dat de vrouw, die twee kinderen had, in een vergelijkbare positie verkeerde met een gehuwde vrouw, on dat het darom discriminerend zou zijn om haar geen vordering met betrekking tot de goederen toe te kennen."

Johnstont lerland, Eur. Hof R.M., 18 december 1989 , serie A nr. $112 \$ 68$.

- Dit was een uitkering die aan de moeder werd toegekend, mits zij in aannerking kwam voor "Wochengeld" (cen witkering die aan moeders in de eerste acht weken na de geboorte wordt betalald) en zij ta de geboorte van het kind sen jaar lang ouderschapsveriof opnam.

10. Petrovic t. Oostenrigk, EHRM, 27 maart 1998, Reports of Judgments and Decisions 1998-11 No. 67, p. 579; , zie ook Duitse Bundesverfassungsgericht, 25 oktober 1994, FamRZ 1995, 86

[III. 1. (c) (a) ].

"Door dit protocol wordi de discriminatiebescherming van artike 14 EVRM uitgebreid. Voor de tekst en explanatory report: NJCM-Bulletin jrg. 24 (1999), nr. 7, pp. 1004-1008.

12 Hokkanent. Fintand, EHRM, 23 september 1994, serie A nr. 299-A \& 60-61; Mowtat Porfugal, EHRM, 21 decenber 1999, Reports of Judgments and Decisions 1998-11, No. 67, 1. 579, 22.

3) Walsh v Bona [2000] N.S.J. No. 117 (april 19, 2000) Nova Scotia Court of Appeal. 


\section{Wat wij weten over ongehuwd samenwonenden}

\section{Demografische gegevens}

Steeds meer paren wonen samen - yoor een deel van hun leven. In het begin van de jarm zestig kwan het ongehuwd samemwonen, toen vaak nog als "hokken" aangeduid, nauwelijks voor in Nederland. In 1961-1965 woonde 1,9 procent van alle startende huishoudens samen; ${ }^{14}$ in 1966-1970 was dit 3 procent. In 1976-1980 woonden 15 procent van alle startende paren samen. ${ }^{16}$ In de jaren $1971-1981$ nam het aantal ongehuwd samenwonenden steeds verder toe; in 1981 woonden 250.000 paren zonder kinderen en 50.000 met kinderen samen. ${ }^{17}$ Het gaat in de periode 1971-1981 vooral om jonge mensen die samenwonen alvorens te trouwen. Voor veel van deze paren was de komst van een kind de reden om te gaan trouwen. In de periode 1981 1995 neemt de populariteit van het samenwonen los van enige trouwplannen toe. Woonden in 19815 procent van alle huishoudens samen, in 1995 is dit 10 procent geworden, waarvan een op de vijf paren met kinderen. ${ }^{18}$ In absolute cijfers gaat het in 1995 om 650.000 samenwonenden, waarvan 130.000 met kinderen. ${ }^{19}$

De praktijk van ongehuwd samenwonen kenmerkt zich door twee ontwikke. lingen. Allereerst wordt de reeds in de jaren zeventig ingezette samenwoning gedurende een 'proefperiode" wór het huwelijk steeds populairder. Tegenwoordig volgt slechts iets meer dan een kwart (26,9 procent) wan de jonge mensen het traditionele patroon van het rechtstreeks vanuit het ouderlijk liuis trouwen. Het gaat hierbij vooral om allochtonen of mensen van traditionele kerk- of geloofsgemeenschappen. De resterende bijna drie kwart van de jongeren verlaat het ouderlijk huis om eerst zelfstandig te gaan wonen ( 36,3 procent) of om te gaan samenwonen ( 29,5 procent) 7,3 procent gaat in groepsverband wonen. ${ }^{20}$ In alle gevallen gebeurt het trouwen op een later tijdstip dan tijdens de jaren zestig of zeventig. ${ }^{21}$ voor veel paren is de beslissing on een kind te nemen aanleiding om te trouwen. Het uitstel van de huwelijkssluiting moet dan ook in verband worden gebracht met het feit dat het krijgen van kinderen wordt uitgesteld. ${ }^{22}$ De tweede ontwikkeling ziet op het geheel afzien van het huwelijk. Het is niet mogelijk om te zeggen om welke aantallen het gaat, omdat de ontwikkelingen nog niet lang genoeg hebben gedurd om het hele levenspatroon van een bepaalde generatie in kaart te brengen, maar een - vermoedelijk klein - deel van de 520.000 ongehuwde paren zonder kinderen en de 130.000 met kinderen lewen langdurig samen zonder ooit te trouwen. ${ }^{23}$ Een recente publicatie van het CBS bevestigt dat per generatie het aantal mensen dat uiteindelijk trouwt steeds verder af-

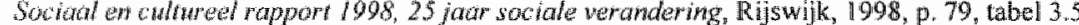

3 Ibid. Het bestatan wan ongehuwd samenwonenden is niet nieuw, matr pas in de jaren zeventig kreeg dit verschijnsel, "mede in verband met deze frequentie," een eigen categorie in de officiête stutistiek. Voor het einde van de jaren zevertigg gingen de samenwonenden schuil onder de catego-

Hid. rie 'overige liwishoudens", Sociach en coltureet ropport, p. 84.

"K. de Hoog, "Verdwijint het "traditionelle" gezin in Nederland", FJR 1999, pp. 209-213, p. 211, 1k hoofd.

De Hoog, aw, a. 17, p. $211,1 k$, voet.

Socical en cullured rapport, p. 79, tabel 3.5 .

Siocioal en cuthered rapport, p. 78 , tabel 3.4 .

32. I. Latten en P.F. Cuyvers, Relatie- en gezinsworming in de jaren wegentig, CBS/Nederlandse Gezinstaad, Voorburg/Heerlen, 1994, p. 46, p. 66.

23 Social en cultureel rapport, p. 78, De Hoog, a.w. n. 17 p. 213. 
neemt. ${ }^{24}$ Volgens een prognose van het CBS zal het aandeel van ongehuwd samenwonenden toenemen wan 14 procent van alle paren in 1995 tot eem werwachte 24 procentin 2015 . $^{25}$

Het is belangrijk om te beseffen dat deze statistieken het resultaat zijn wan een momentopname. In de meerderheid van de gevallen is er een periode van samenle. ven, gewolgd door een huwelik met dezelfde of een andere partner. Men spreekt van een relatie-biografie. ${ }^{26}$ De toename in het samenwonen hangt samen met het feit dat de periode van samenwonen bij een toenemend aantal mensen steeds langer wordt. Hoewel de demografische ontwikkeling zich kenmerkt door een steeds grotere diver. siteit van samenlevingsvomen (alleenstaanden, samewwonenden, samenwoning in groepsverband), is het uiteindelijke doel van de meeste mensen nog steeds - zij het soms op langere temijn - de vorming van een exclusieve twee-relatie met kinderen. ${ }^{27}$ Er zijn veel aorzaken voor deze ontwikkelingen (uitstel en afstel van het hwwelijk) die men globaal onder de noemer van modernisering of individualisering kan brengen. ${ }^{28}$ In een Europees onderzoek is een correlatie gevonden tussen vrouwen die een scheiding van hun eigen ouders hebben meegemaakt, en de neiging om later in plaats wan het huwelijk voor samenwoning te kiezen ${ }^{29}$ Een interessante hypothese is dat vrouwen, in de wetenschap dat zij in de relatie doorgaans economisch afharkelijk van hun echtgenoot zullen zjin, het trouwen en het krijgen van kinderen uitstellen totdat zij er zeker van zijn dat de partner iemand is op wie zij kunnen rekenen.

Buitenechtelijke geboorten komen steeds neer voor. Terwijl in 19601,4 procent van alle geboortes buitenechtelijk was, was dit aandeel in 19702,1 procent, in 19804,1 procent, in 199011,4 procent en in 199617 procent. ${ }^{30}$ In tegenstelling tot vroeger beperken buitenechtelijke geboorten zich niet tot louter jonge vrouwen. Heden ten dage is een typische buitenechtelijke geboorte geen vergissing, zoals vroeger, maar het gevolg van een bewuste keuze van veelal samenwonende ouders. ${ }^{31}$ Ook deze statistieken zijn het resultaat van een momentopiame. Het axtatal kinderen dat buitenechtelijk wordt geboren en ook buitenechtelijk blijft is betrekkelijk klein. In veel gevallen trouwen de ouders na de geboorte van het kind. Slechts een tiende misschien iets meer - van alle eerstgeboren kinderen blijft buitenechtelijk ${ }^{32}$ Nietgehuwde paren met kinderen vormen 5 procent van alle gezinnen met kinderen. ${ }^{33}$

"Groot alantal huweliken, maar trotwen is niet "in" ", MRC Handelablad, 16 matat 2000, p. 2.

25 A.H. de Jong "Nationale huishoudensprognose 1996: steds minder paren zijn gehuwd", in: Madndsatistiek wan de bevolking (1997) 5 (18-28). Latten/Cuyvers, (red.), a.w. n. 22, hifst. 4.

27 Sociacl en cultureel rapport, $7.79,85$.

23 Sociad en culturcel rapport, p. 78; G.A. Kooy, 'Gezinsleven en rechi in naoorloges Nederland', R MThemis 1997, jrg 158 , pp. 123-129.

zo Kathleen Kieman, 'Cohabitation in Western Europe', Population Trends (Office for National Statistics) 1996, summer 1999, pp. 25-32, p. 31, table 10.

30. Sockal en culturee rapport, p. 81, tabel 3.7; O.A. Kooy a.w, n. 28, p. 126; in 1998 waren er 26691 buttenechtelijke geboortes, en een totad van 199408 geboortes, CBS statistieken geboorte $1994-1998$, tabel 2 , p. 36 .

32 Latten/Cuyvers, a. w, m. 22, p. 73 .

33. Sociad ens cullureel rapport, p. 77 , tabel 3.2 . 
Over de ontbinding vain de samenwoningsrelathe zin gen harde cijfers beschikbaar. Op basis van het "Onderzok Gezinsvorming" wordt het aantal ontbindingen in 1993 geschat op 40.000 . In hetwelfde jaar waren er 30.000 echischeidingen. ${ }^{34}$

Hoe vaak kornt buiterithwelijkse samenwoning in Nederland voor in vergelijking met andere Europese landen? In 1996 is naar dit verschijnsel in de vijtien landen die toen de Europese Gemeenschappen uimakten onderzoek gedaan. ${ }^{35}$ Uit dit zogenoemde Eurobarometeronderzoek bljki dat de frequentie van samenwoning in Nederland iets boven het gemiddelde is. In Denemarken, Zweden, Finland en frankijk is de frequentic van ongehuwde samenwoning hoog: ongeveet 30 procent wan wouwen in de leeftijd van 25-29 woont ongehuwd samen. Nederland behoort tot de middenmoot met Belgie, Groot-Britanie, Oost- en West Duitsland, en Oostenrijk, met gemiddeld 8 tot 16 procent van vrouwen in de leeftijd $25-29$ jaar die ongetrouwd samenwoonden. Nederland voert deze groep wel aan met een percentage van 16. Ongehuwd samenwonen komt het minst voor in Zuid-Europa en lerland. In deze landen bedraagt het percentage van wrouwen dat ongetrouwd samenwoont in de leeftifd van $25-29$ jaar 3 procent of minder.

De demografische gegevens samenvattend kan worden gezegd dat steeds meer personen in Nederland gedurende een deel van hun leven samenwonen, en zulks voor steeds langere perioden. Hoewel het betrekkelijk weinig voorkomt dat ongehuwd samenwonenden, die samen een kind krijgen, ook ongehuwd blijven, is dit aen miet te verwaarlozen verschijnsel. Het percentage van ongehuwde paren die uit elkaar gaan ligt wermoedelijk hoger dan het percentage echtscheidingen.

\section{Sociologische gegevens}

Tegen het einde van de jaren zeventig is in Nederland een juridisch-sociologisch onderzoek (hierna: het NISSO-onderzoek) verricht bij 75 niet-gehuwde relaties, waaronder hetero- en homoseksuele relaties, met en zonder kinderen, wit alle lagen. van de bevolking. ${ }^{36}$ Hoewel dit onderzoek vrij oud is, verdienen de bevindingen nog steeds de aandacht. Het gaat om een kwalitatief onderzoek, waarin is nagegaan hoe ongehuwd samenwonenden over hun relatie denken, hoe zij hier in de praktijk invulling aan geven, hoe, en of, zij afspraken en/of regelingen maken en over welke onderwerpen, en of zich knelpunten voordoen in hun relatie. Onderzocht is dus het samenwonen als fenomeen, warbij is nagestreefd om zoveel mogelijk een sellectie wan alle mogelijke verschijningsvormen onder de loep te nemen. De veronderstelling lijkt gerechtvaardigd dat de sociologisehe bevindingen uit dit onderzoek hun gelding hebben behouden voor de huidige ongehuwd samenwonende paren. De juridische bevindingen en anbevelingen wit dit onderzoek zijn echter sterk verouderd.

Uit het onderzoek komt naar woren dat wan paar tot paar zeer verschillend wordt gedacht over het relatiemodel waamaar wordt gestreefd en over de praktische uitwerking hiervan. Ondanks deze verscheidenheid hebben de onderzoekers een cruciale scheidslin ontdekt tussen de "samen delers" en de "samen zelfstandigen". "Samen delers" zujn paren die bereid zijn elkaar, zo nodig, te onderhouden; samen

D. Manting; "Meer scheidingen dan echtscheidingen", Maandstatistiek wan de bevolking CBS, jrg. 42, 1994-4, pp. 6 ev. (TK 1995-6, 22 700, nar. 6, p. 5-6.); Latten/Cuyvers (red) a.w. n. 22, p. 53 .

3 Kiernam, a.w. n. 29.

is C.I. Straver, A.M. van der Heiden, W.C.J. Robert, Twee relaties, anders dan her huwelijk? Samson sociale en culturele reeks, Alphen aan den Rijn, Brussel, 1980. 
zelfstandigen wijzen een onderhoudsfunctie in hun relatie af ${ }^{37}$ Binnen deze twee categorieen bevindt zich een breed seala aan variaties. "Samendelers" behoeven bijvoorbeeld niet noodzakelijkerwijs samen te wonen of een gemeenschappelijk vermogen te hebben. ${ }^{32}$ Gelet op dit gegeven dient de jurist ervoor te waken ongehuwd samenwonenden en gehuwden op én lijn te stellen en ongeluwd samenwonenden te behandelen alsof het om een homogene groep zou gaan. ${ }^{31}$ In een verwolgonderzoek is nagegaan hoe gehuwden aan hun relatie invulling geven. ${ }^{40}$

In een Amerikaans onderzoek ${ }^{41}$ dat rond dezelfde tijd als het NISSOonderzoek werd uitgevoerd, is een vergelijking gemakt tussen gehuwden en ongehuwden. In dit onderzoek is een groep studenten sociologie gevraagd om intieme contracten - dat wil zeggen een contract tussen werloofden, samenwoners of gehwwden * op te stellen, hetzij voor hun eigen relatie, hetxij woor een relatie tussen bekenden. Dit onderzoek heef 59 contracten opgeleverd. Ter nadere analyse zijn deze onderverdeeld in contracten voor gehuwden, voor verloofden en voor samenwonenden. Hoewel de waarde van dit onderzoek door het beperkt aantal respondenten en het selecte karakter van de groep niet mag worden overschat, bevat het aen antal interessante gegevens. Zo bleek dat samenwoners meer dan gehuwden of verloofden geneigd waren tot het treffen van voorzieningen voor gescheiden bezit, gescheiden schulden, en gescheiden onderhoud. Zij waren eveneens meer geneigd een lijst te maken van hun bezittingen en hun inkomens gescheiden te houden. Kortom, in bun contracten benadrukten zij hun individualiteit en zelfstandigheid, waarin zij zich onderscheidden van gehuwden en verloofden. ${ }^{42}$

Voor een karakterisering van de relatietypen in Nederland wijs ik op het onderzoek van Van der Avort. Naar aanleiding van diepte-gesprekken met 25 gehuwde paren en 24 ongehuwde paren heeft Van der Avort een onderscheid gemaakt tussen drie relatietypen. A.ls eerste onderscheidt hij het partnerschapstype, waarin vooral de samenwonenden vertegenwoordigd zijn. De basiskemmerken van dit type zijn kameraadschap en individualiteit. In deze relaties streven man en vrouw na gelijke functies in de relatie te vervullen. Het tweecle type, het relatie-lype of burgerlijk model, heeft als basiswarde gezinseenheid en kameraadschappelijkheid en is veel minder individualistisch ingesteld dan het eerste model. Deze paren, die owerwegend gehuwd zijn, strewen er niet naar om de taken gelijkelijk te delen, maar zien elkaar als elkaars complement. Het derde relatie-type ziet op de situatie waarin de ene partner het relatie-type nastreef en de andere het partnerschapstype. Een belangrijke verdienste van het onderzoek van Van der Avort aclit ik dat daaruit naar voren komt dat de huidige ontwikkelingen binnern relaties niet moeten worden opgevat als een geldidelijke verzwalking wan de bindingen tussen paren. In deze "aforaak-visie" is er cen

Tbid., pp. 130-146

9 Van Mourik, a.w. n. 5, p. 67.

4i C.J. Straver, A. M, van der Heijden, R. W.F. van der Vliet, De Huwelijkse logica, hwwelijksmodel en iwrichting wain het samenleven bij arbelders en anderen, NISSO, DSWO Press, Rijkswiniversiteit Leiden, 1994.

4 L. Weitznan, The Marriage Contrad, A Guide to Living with Lovers and Spowses, Macmillan/Free Press, New YorkflLondon, 1981, pp. 417-458; Nederfandse wertaling: L. Weitzman, C. Dikon, J. Adair Bird, N. MicGinn, D.M. Robertson, 'Contracten woor intieme relaties', in: CD, Saal en C.J. Straver (red.), Samonlewer in meervoud, furdische en sochologische aspecten van het samenwonen zonder huwelijk, Samson sociale en culturelse reeks, Alphen aan den Rijn, Brussel, $1981, \mathrm{pp} .87-138$.

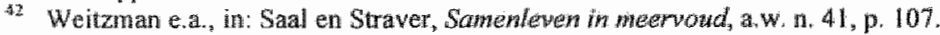


beweging weg van het huwelizk in de richting van toenemende individualiteit. Volgens Van der Avort is dit niet het geval. Naar zin mening is er veeleer sprake van wen ontwikkeling warbij de partners streven naar een evenwicht tussen binding en individualiteit binnen de relatie." Deze benadering is belangrijk voor juristen, want, zoals bij do hiema volgende juridische bespreking nog zal bliken, wordt het samenwonen sterk in verband gebracht met individualiteit. Volgens Van der Avort kenmerkt wen relatie van samenwonenden zich door een combinatie van binding en individualitert. Van belang is voorts dat uit het onderzoek naar voren komt dat samemwonenden zich vooral in midden en hogere sociale niveaus bevinden. ${ }^{44}$

Een interessante aanvulling op het NISSO-onderzoek is het recentelijk in Engeland uitgevoerde onderzoek van Carol Smart en Pippa Stevens. ${ }^{45}$ In dit onderzoek zin diepte-interviews gehouden met twintig paren van ongehuwd samenwonende mannen en vrouwen die samen een kind hebben opgevoed en wier relatie inmiddels beendigd is. In dit onderzoek gaat het om vragen als: hoe zijn de partners met de samenwoning begonnen; was er ooit sprake van huwelijksplannen; hoe waren de verantwoordelijkheden tijdens de relatie verdeeld; hoe werd de beslissing om een kind te nemen gemaakt, en waarom is men witeindelijk wit elkaar gegaan. Ook van belang was de perceptie wan samenwonenden op hun juridische positie.

Dit Engelse onderzoek kan beschouwd worden als een aanvulling op het NSSO onderzoek, ondat dit laatste onderzoek uitsluitend respondenten betreft die hebben samengewoond met iemand met wie hij of zil kinderen had. Bovendien biedt het Engelse onderzoek een ander perspectief dan het NISSO-onderzoek, nu het hierbij gaat om opvattingen over inmiddels verbroken relaties. Het Engelse onderzoek was vooral gericht op het vinden van aanwijzingen en verklaringen voor de veronderstelde geringere bestendigheid van de relatie van samenwonenden in vergelijking tot het huwelijk. ${ }^{46}$ Uit dit onderzoek blijkt onder andere dat een ongeplande zwangerschap aanleiding kan zajn tot samenwoning. Het gat hierbij om vouwen die enerzijds de opties van zwangerschapsafbreking of alleenstaand ouderschap afwezen, maar anderzijds een huwelijk te riskant vonden. ${ }^{47}$ Om te analyseren hoe de samenwonenden over hun relatie dachten, makten de onderzoeksters een onderscheid tussen, enerzijds, respondenten die een hechte band met elkaar hadden ${ }^{48}$ en, anderzijds, respondenten die een relatie hadden waarin deze hechte band (nog) niet aanwezig was en waarbij zij meenden dat een dergelijke band slechts onder woorwaarden kon ontstaan (voorwaardelijke relatiles). Voor het aanmemen van een hechte band achten de onderzoeksters van bellang dat de partners zich samen rekenschap hadden gegeven van het ontstaan van de relatie, alsmede van de wijze waarop deze door beiden werd ingevuld en afgebakend en dat de partners stappen thadden genomen voor het geval dat zij uiteen zouden gaan. Voorwardelike relaties zijn volgens de onderzoeksters gebuseerd op een kans of gelegenheid die zich voordoet. Meestal wordt gehoopt dat de relatie en/of de partner zich gaat verbeteren. Deze verwachtingen zijn meestal niet uitgesproken. Van het bestaan van een hechte band werd uitgegaan wanneer de rela-

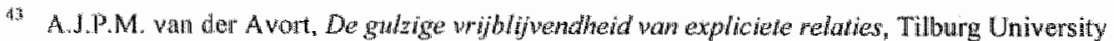
Press, 1987, p. 297.

45 C. Smart en P. Stevens, Cohabitarion Breakdown, Family \& Parenthood, Poltcy a Practice, Fa mily Policy Studies Centre, Joseph Rowntree Foundation, London, 2000.

th Strant and Stevents a.w. 1. 45, p. 13 .

47 Smart and Stevens, a. W. n. 45, p. 23.

4* Diti voor de onderzoeksters centrale begrip conwy itwent laat zich moeilijk vertalen. De betekenis die er het dichsst bij in de bunt kont is: sterk aan elkaar sterk gehechi zijn. 
tie voorafgaand aan de samenwoning was ontstaan, er enkele juridische en financiële afspraken waren gemaakt, de kinderen waren gepland, de partners de kinderen samen opvoedden, zij zich hadden uitgesproken over de werwachtingen die zij van elkaar hadden, en de partners er van uitgegaan zijn dat de relatie een toekomst zou hebben. ${ }^{49}$ Van een voorwaardelijke relatie werd uitgegaan alls de partners nog niet lang samenwoonden, er geen juridische of financiele afspraken tussen hen waren gemaakt; de kinderen niet gepland waren (wat niet betekent dat zij niet waren gewenst), de vrouw zwanger was vóór de aanvang wan het samenwonen, éćn van de partners eiste dat de andere zijn/haar gedrag of persoonlijkheid zou veranderen of de partners veronderstelden dat hun relatie niet duurzaam zou zijn maar zij hierop slechts hun hoop hadden gevestigd. ${ }^{50}$ In vele gevallen van 'voorwaardelijke relatie' speelde geweld en/of werkloosheid een rol.

Samenvattend: individualiteit en onafhankelijkheid zijn elementen die een belangrijke rol spelen in de relatie van samenwonenden. Maar wij kunnen hieruit niet de conclusie trekken dat er daarom geen sprake is van binding en afhankelijkheid.

\section{Onderhoudsverplichting}

In principe zijn ongehuwd samenwonenden niet onderhoudsplichtig jegens elkaar, niet tijdens de relatie ${ }^{51}$ en ook niet na de beêindiging hiervan. ${ }^{52}$ Zo rustte op mewrouw wan Dillst geen verplichting om de heer Roozendaal, die enige tijd met haar had samengewoond, te onderhouden toen deze laatste werkloos was geworden. Daaraan kon niet afdoen dat de gemeente Leiden vond dat de situatie van Roozendaal en van Dilst niet wezenlijk verschilde van die van een huwelijk, zodat Roozendaal slechts fl. $67,--$ per maand aan bijstandsuitkering ontwing. ${ }^{53}$ Partijen kunnen een onderhoudsverplichting doen ontstaan door een alimentatieverplichting in een samenlevingsovereenkomst op te nemen. Soms biedt het recht ook een oplossing aan samenwonenden die deze stap niet hebben gemaakt. Zo kan een onderhoudsverplichting door stilzwijgende afspraak geacht worden te zijn ontstaan. In dat geval wordt de bedoeling van partijen om een samenlevingsoverkomst aan te gaan afgeleid uit bepaalde handelingen waaruit deze bedoeling blijkt. Hierbij kan men denken aan de situatie waarin een partner op verzoek van de andere partner zijn of haar baan opzegt om het huishouden te verzorgen ${ }^{54}$, om kinderen te krijgen en deze in gezinswerband op te voeden of aan gevallen waarin de samenleving van zeer lange dutur is. $^{55}$

Voorts kan een verplichting ontstaan die hetzelfde effect heeft als een onderhoudsverplichting. Onder zeer bijzondere omstandigheden is het mogelijk dat het gedrag van een partij bij het aangaan van de samenleving of bij de verbreking hier

s1 HR 22 februari 1985, ND 1986, 82, m. nt. Luijten, 0.W. 3.2, conclusie mr Moltmaker 3.3.2; HR 15. juli 1985, NJ 1986, $397 \mathrm{~m}$. nt. Luigten, o.w. 3; HR 9 januari 1987, NJ 1987, $927 \mathrm{~m}$. nt. Luiiften, a.w. 3.2 .

s. Rb. Groningen 9 januari 1979 , NJ 1979, 351 .

53. HR, 9 januari 1987 , NJ $1987,927 \mathrm{~m}$. mt. Luitten.

5. Zie de conclusie wan A-O Leijten woor HR 9 januari 1987, NJ 1987,927 m. nt. Luijten, B. 11.3 voor het voorbeeld van de broer en zus die geacht worden stilzwiiggend te hebben afgesproken dat die zus de huishouding zal doen, terwijl de broer buitenshisus werkt.

\$5 W. J.M. Davids, 'Alimentatie ..niet in de lengte, wel in de breedte? in: Henrigwez Bundel, p. 82. 
van een onrechtmatige dad oplevert, waruit een verplichting tot schadevergocding ontstad ${ }^{56}$ Ook kan et sprake zin van ongerechwardigde verriking. "Tot slot is de toepassing van art. $255 \mathrm{sr}^{5}$ denkbar.

Er schuil sen inconseguentie in artikel $4: 160$ BW warin is bepaald dat een onderhoudsverplichting wit hoofde van een chtscheiding (of onbinding van een partherschap) ophoudt te bestatan wamner de almuentategerechtigde 'opnieuw in het hwwelik treedt, een geregisteerd partnerschap aangaat dan wel is gaan samenleven met een ander als waren zil gehwd of als hadden aj hun partmersehap laten registre ren." De inconseguentie bestaal hierin dat een wrouw die recht op alimentatie heef van haar ex-echtgenoot en die later met lemand gaat trouwen of een partnerschap aingat, op grond van artikel $1: 160$ BW opneww recht verkrigt op almentatie - en wel jegens de nieuwe partner - terwijl dit recht wordt onthouden an de vrouw die weer gat samenwonen. De toepassing wan artikel 1:160 BW op samenwonenden is vooral om deze reden an kritiek onderworpen. ${ }^{59}$ De toevoeging van samenwonenden aan artikel 1:160 BW is bij amendement geschied, teneinde te voorkomen dat een alimentatiegerechtigde, on de alimentatie van haar ex-echtgenoot te behouden, er de voorkeur adn zou geven on met een nietwe parther te gaan samenwonen in plaats wan te trouwen. Volgens Asser-De Boer was de toevoeging echter niet nodig, ondat de rechter op grond wan artikel 1:401 BW altijd de bevoegdheid heeft de alimentativerplichting te wijzigen in omstandigheden warin de redelijkheid dit vereist. ${ }^{601}$ Daarbij kan zeker ook worden gedacht aan de situatie waarin de alimentatiegerechtigde gaat samenwonen. Interessant is in dit verband het gegeven dat in 1978 in Zweden een soortgelijke bepaling als $1: 160 \mathrm{BW}$ is geschrapt en dat dat voortaan een reeds bestande, op artikel $1401 \mathrm{BW}$ lijkende, bepaling werd toegepast. De reden was ook daar dat gevreesd werd dat eerstgenoende bepaling mensen ertoe zou brengen on niet te hertrouwen, maar met een nieuwe partner te gaan samenwonen. ${ }^{61}$

In verband met de zeer ingrijpende consequenties die aan de toepassing van art. : : $160 \mathrm{BW}$ zin verbonden geeft de Hoge Raad an het begrip 'samenleven met een ander als waren zij gehuwd" een zeer beperkte witleg. Een "samenleving met een ander als waren zij gehuwd" heeft de kenmerken wan een normale huweliksverhouding, ${ }^{62}$ waronder volgens de Hoge Raad dient te worden verstaan: 'die volledige, tot lotsverbondenheid leiderde levensgemeenschap, welke het kenmerk is van een normaal huwellik'. 63 In ieder geval is vereist dat de partners samenwonen en elkaar we-

56. Zhe het voorbed genoend door Devids, a w. n. 55, p. 77-78; 1.A. Nota "Gewoon samemwonen",

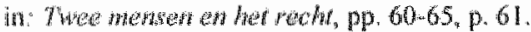

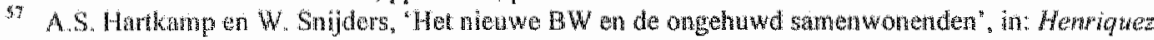

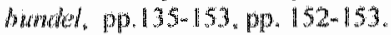

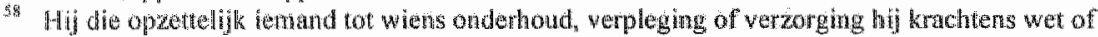

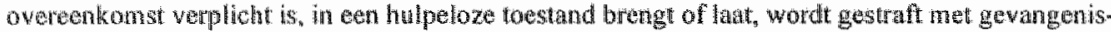

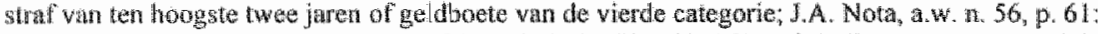
HR 8 anei $1951, N J 1951,523$; HR 18 februari 1958, NJ 1958,373, ook indien de persoon op bij-

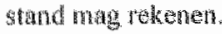

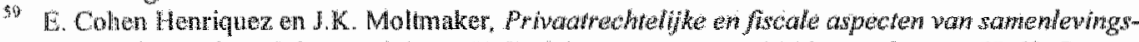
wornen bwiten hawelij, preadwezen KNB, Kluwer, Deventer, 1977, pp, 27-28 en 67-68: Staver

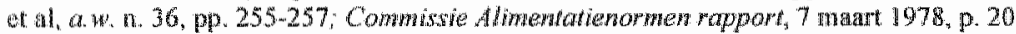

40 Aser De Bor, D. 464

4 A. Agell. Samenwonen Londer huwelijk, in: C.D. Salhen C.J. Straver (red) Samemlewen in Meer-

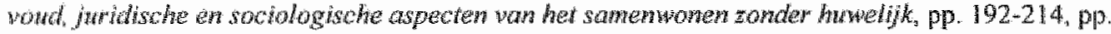
197.198

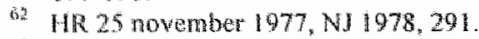

4 HR 2 april 1982, N 1982,374 m. nt Luifen. 
derzijds verzorgen. Voorts geldt als belangrijke eis dat de partiners een conomi. sche eenheid women. ${ }^{65}$

\section{Beschouwing}

Het ontbreken wan een wettelijke regeling wan de alimentatieverplichting voor samenwonenden $z a l$ in bepaalde situaties tot onbevredigende resultaten leiden. Het ontbreken van deze verplichting zal met name problemen kunnen opleveren in situaties warin een van de partners in verband met het huishouden en de verzorging van de kinderen langdurig niet heeft gewerkt of een veel lager inkomen heeft dan de andere partner. In de meeste gevallen waarin een onderhoudsverplichting gerechtvaardigd en wenselijk is, lijkt de mogelijkheid van her anmemen van een tot een dergelijke strekkende stilzwijgende overeenkomst uitkomst te bieden. Toch valt te betwijfeten of in deze constructie voor de huidige situatie een afdoende oplossing is gelegen. Het mag opmerkelijk heten dat er geen rechterlijke uitspraken zijn over de omvang van de alimentieverplichtingen tussen ongehuwden, zulks in schril contrast tot de onophoudelijke stroom van rechtszaken over draagkracht en behoefte in werband met de alimentatieverplichtingen van gehuwden. ${ }^{66}$ Deze stilte is des te opvallender, omdat het toch in de lijn der verwachting ligt dat er geschillen zullen rijzen over de interpretatie van een eenmal aangenonien stilzwijgende overeenkomst. Daarbij vall in het bijzonder te denken an vragen met betrekking tot de duur en omvang van de alimentieverplichting. Dat er in de meeste gevallen geen behoefte zou bestaan aan een alimentatieregeling lijkt in het licht van de demogralische gegevens niet waarschijnlijk. Dat er in menig geval sprake zal zijn van economische afhankelijkheid laat zich onder meer afleiden uit het toenemende antal ongehuwd samenwonenden die kinderen hebben (in 1995:130.000). Dalarnaast bestaat bij oudere samenwonenden een verhoogd risico dat een van de partners ziek wordt en daardoor mogelijk economisch afhankelijk wordt van de andere partner.

De verklaring voor de afwezigheid van procedures over alimentatie tussen exsamenwoners is te vinden in het publiekrecht. Het ligt voor de hand dat een exsamenwoner die niet in staat is in zijn of haar onderhoud te voorzien, een beroep zal doen op de Algemene bijstandwet. Als echter de onderhoudsplicht tussen exsamenwoners wettelijk geregeld zou zijn, zou de gemeente kunnen vorlangen dat van de wettelik aanspraak gebruik word gemaakt. Het zou in dat geval ook logisch zijn als de gemeente een eigen verhaalsrecht zou kriggen jegens de ex-lefgenoot.

Mocht het tot een wettelike regellng van de onderhoudsverplichting tussen ex-samenwoners komen, dan is te verwachten dat de onderhoudsgerechtigde er in verreweg de meeste gevallen geen cent wijzer van wordt dan nu het geval is. Dit zou slechts anders zijn als de toepassing van de privaatrechtelijke nomen draagkracht en behoefte, gelet op de levensstandaard van het paar, het gevolg zou hebben dat de alimentatie hoger is dan de bijstandsnorm. Aldus is denkbarar dat de ex-samenwoner voor whe champagne en kaviaar dagelijkse kost waren beter af zou zijn dan de exsamenwoner die zich met slechts krumige aardappels tevreden heeft moeten stollen.

HR 22 februari 1985, NJ 1986, 82; HR 25 november 1994 , NJ 1995, 299 m. nit de Boer.

HR 22 februari 1985 , NJ $1986,82 \mathrm{~m}$. nt. Luijten; F/R $1986,112 \mathrm{~m}$. nt. Hammerstein-

Schoonderwoerd; HR 14 januari 1994, NJ 1994 333; HR 25 november 1994 , NJ 1995,299 , m.nt.

de Boer

tor personemen fomilierech, Kluwer, Aant art 1:157 (S.F.M. Wortmanm). 
Dat het hierbij net om en louter denkbeldige situatie gat blikt wit het hiervoor besproken empurisch onderzoek van Van der Avort, dat heef urigewezen dat samenwonenden zich vooral op de midden en hogere sociale niveaus bewinden. Het komt mil als redelik voor dat de onderhoudsgerechigde die aan een hogere levensstandard gewend is geraakt, dienoveremikomstig alimentatio zou ontwangen.

Naar huidig rechl ligt de drempel voor het woeren van een procedure om het onderhoud te vorderen warschijnlijk te hoog. gelet op de proceskosten en de hiervoor besproken onzekerheden of een onderhoudsverplichting zal: kunnen worden vasitgesteld.

Het lijkt mij woorts redelijk dat, ook als het bedrag dat de onderhoudsplichtige overcenkomstig de privaatrechtelijke normen moet betalen beneden het niveau van de bijstaand Jigt, het geld aan de gemeente ten goede komt. Voorkomen moet immers worden dat de ex-leefgenoot die een financieel dominante positie innam tijdens de relatie in een betere positie tegenover de gemeente zou komen te verkeren dan de exechtgenoot.

Ook de theorie op het punt wan de alimentatie is onbevredigend. Bij de bespreking van de goederen in de samenwoningsrelatie zal ik nader ingaan op de bezwaren tegen de rechtsfigur van de stilzwijgende overeenkomst in de relatie tussen samenwonenden. Hier volsta ik met de wolgende. Volgens het huidige recht moet de partij die alimentatie wil vorderen de aanwezigheid van een stilzwijgende owereenkomst bewijzen. Ik betwijfel echter of in de overeenkomst wel de juiste rechtsgrond is gelegen voor het toekennen wan alimentatie tussen ex-samenwonenden. Mijns inziens zou de rechtsgrond dezelfde dienen te zijn als die voor de alimentatieverplichting van gehuwden en ex-gehuwden. Deze rechtsgrond is door de Hoge Raad als volgt verwoord: "de levensverhouding, zoals die door het huwelijk is geschapen en die haar werking, zij het in beperkte omvang behoudt, ook al wordt de huwelijksband gebeel of ten dele geslabkt." ${ }^{67}$ De levensverhouding van de partijen tijdens de samenwoning, de invulling die zij aan hum relatie geven, is iets anders dan een overcenkomst. Mijns inzlens is de grondslag voor de alimentieverplichting gelegen in de levenswerhouding waarin partijen tijdens de samenwoning tol elkaar staan, anders gezegd in de invulling die de partners aan hun relatie geven. $Z \mathrm{Ee}$ is, in de bewoordingen wan recente rechtspraak van de Hoge Raad, gelegen in de levensgemeenschap die tussen partijen tijdens hun relatie is ontstaan ${ }^{68}$. Weliswaar zal in veel gevallen een stilzwijgende overeenkomst wit de levensverhouding van de partijen kunnen worden afgeleid, mear dit zal nict altijd het geval zijn. Zoals hiervoor al is opgemerkt kan een alimentatieverplichting immers eveneens gebaseerd zijn op een door de ene jegens de andere partne gepleegde onrechtmatige daad of op ongerechtvardigde verrijking wan de ene partner ten koste van de ander. Deze positiefrechtelijke aanknopingspunten voor het aannemen van een alimentatieverplichting zijn mijns inziens echter alle terug te woren op de levensgemeenschap die tussen partijen door het samenwonen is ontstatin.

Zowel on deze doctrinare reden als on de hiervoor genoemde praktische redenen komt een speciaal op de alimentatieverplichting van samenwonenden toegesneden wettelijke regeling mij zeer wenselijk voor.

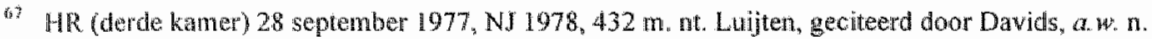
55. 1. 83: HR 14 november 1997, NJ 1998, 112 0.w.3.3.

4h HL 14 novenber 1997, NJ 1998, $1120.4 \% 3.3$. 
Vanwege de verscheidenheid in de wijzen waarop de partners in de praktijk aan hun samenwoningsrelatie invulling geven en in de verschillende bedoelingen die hun daarbij voor ogen staan, is het miet eenvoudig een regeling te treffen waarbij voldoende onderscheid wordt betracht tussen relaties waarvoor een onderhoudsregeling wel passend zou zijn en relaties waarvoor deze achterwege zou moeten blijven. De regeling zou in een onderhoudswerplichting moeten voorzien voor de in het NISSOonderzoek onderscheiden categorie van 'samen-delers', maar niet voor de 'samernzelfstandigen". Volgens het voorstel van Davids zou de verplichting alleen ontstaan wameer

'een samenleving zo innig was, dat er een lotsverbondenheid is ontstaan, die de plicht tot een billijke vereffening van haar economische nadelen doet ontstaan'.69

Deze definitie heeft het voordeel dat ze aansluit bij het begrip 'Iotsverbondenheid' dat in de rechtspraak over artikel 1:160 BW is te vinden. Met dit begrip kan de Nederlandse rechter goed uit de voeten. Bovendien, zoals ik hieronder aan de hand van een bespreking van de Canadese regelingen zal verdedigen, is het zeker toe te juichen dat 'economisch nadeel' een integraal onderdeel vormt van het begrip.

In andere voorstellen is aansluiting gezocht bij de duur van de relatie, ${ }^{70}$ bij het criterium van economische verzorging ${ }^{71}$, dan wel bij een combinatie van beide. Een voorbeeld van het laatste biedt het voorstel van Minkenhof volgens wie aan de volgende drie vereisten moet worden voldaan:

(a) er is een langdurige samenleving geweest, van minimaal tien jaar, of de alimentatiebehoeftige verzorgt de gemeenschappelijke kinderen of kinderen van de kostwinner of heeft deze verzorgd;

(b) de allimentatiebehoeftige is behoeftig in strikte zin;

(c) er bestaat een causaal verband tussen de behoeftigheid en het geweest zijn van huishoudelijke partij. ${ }^{72}$

Dit voorstel voegt een tijdscriterium toe aan het voorstel van Davids. Bovendien is het zeer specifiek over de oorzaak van de afhankelijkheid. Beide elementen verdienen bespreking.

\section{De duur vam de relatie}

Artikel $408 \mathrm{~b}$ van het ontwerp voor een nieuw Burgerlijk Wetboek van de Nederlandse Antillen en van Aruba (1997) luidt:

"Hebben twee personen langdurig samengeleefd als waren zij gehuwd en is aan deze samenleving anders dan door de dood een einde gekomen, dan kan de rechter, indien dat redelijk is, aan een wan hen op diens verzoek ten laste van de ander een uitkering tot levensonderhoud toekennen. Het bepaalde omtrent een uitkering tot levensonderhoud aan een gewezen echtgenoot is van overeenkomstige toepassing.'

P.P. Lampe, 'Alimentatie ell concubinata', NVB' 19751163.

A.M. var de Wiel, 'Alimentatie en concubinaat' $M \cdot B B$ 1976, 191

72 A.A.L. Minkenhof, "Enikele betwistbare stellingen ter animering van de discussie" met reactie P. Neleman, "De positie van de huishoudeligke partij", in: Relatievrijheid en rech, pp. $119 \mathrm{~m} 137$. 
Dezelfde bepaling staat overigens, niet geheel toevallig, ${ }^{73}$ opgenomen in het ontwerp BW van Eritrea, artikel 708 van Bock 1 . $^{74}$

Nar aanleiding van deze bepaling kan discussie ontstaan over de vratag "hoe lang is cen langdurige samenleving?" Twee jaar? Viff jaar? Then jaar? Langdurigheid is een betrekkelyk begrip warin een cultureel element schuilt. Als de gemiddelde samenworning slechts achttien maanden duurt, is cen samenwoning van wee jaar lang. Voorts kan de duur van de gemiddelde samenwoning verschillen al naar gelang van de leeftjd wan de betrokkenen. Warschinijk bestaat er op de Nederlandse Antillen behoefte aan een betrekkelink open regeling.

Een groter bezwarar is dat het NISSO-onderzoek heeft witgewezen dat de duur van de relatie geen goede maatstaf is voor het al dan niet aanwezig zijn van cen onderhoudswerplichting. Uit de duur van de relatie alleen kan niet worden afgeleid welk relatiemodel de partners nastreven, welke afspraken hiertoe tussen hen zijn gemaakt en welke invuling zij aan hun relatie hebben gegeven." Ook in het geval van een kortdurende relatie is goed denkoaar dat de partners de bedoeling hebben elkaar te onderhouden en zij ook naar dit voomemen handelen. Ik acht het bezwaarlijk dat de Nederlands-Antilliaanse regeling in dergelijke situaties geen uitkomst biedt.

\section{De oorzad van de afhankelilkheid}

Als er weliswar sprake is van een langdurige relatie, maar de aard daarvan en de bedoelingen wan de partners zich tegen een onderhoudsverplichting verzetten, heeft de Anthliananse rechter de (discretionaire) bevoegdheid een onderhoudsverplichting vast te stellen 'indien dat redelijk is." De vraag rijst of deze bepaling niet wat al te open is. Volgens de Memorie van Toelichting dient de rechter te letten op alle omstandigheden van het geval, waarbij te denken valt 'aan leeftij, gezondheidstoestand en arbeidsverleden, de tijdens de samenleving aangehouden rolverdeling, de duur van het concubinaat, het feit dat uit het concubinaat kinderen zijn geboren, de leeftijd van de kinderen, eventuele afspraken ter zake, enz. ${ }^{, 76}$ Naar mijn mening zou deze bevoegdheid van de rechter beperkt moeten blijven tot de situatie waarin de partners een zodanige invulling aan hun relatie hebben gegeven dat de ene partij economisch afhankelijk is geworden van de andere partij.

Bij het huwelijk geldt dit causaal werband daarentegen niet Raakt een exechtgenoot na cle scheiding invalide, dan kan deze wel om wijziging (verhoging of begin van alimentatiebetaling) verzoeken. Dat de eis van causaliteit ten aanzien van almentatieverplichtingen tussen ex-samenwoners wel moet worden gesteld, is terug te voeren op de arard van de samenwoningstratie. Samenwoning heeft eerder dan het huwelijk een tijdelijk en voorwardelijk karakter. Het overheersende beeld is dat het bij aen samenwoningstelatie niet gaat om een 'door dik en dun' samen zijn, maar eerder on een samen zijn "zolang het goed gaat". Het vereiste van het causaal ver-

3) Boek I wan het ontwerp BW van Eritrea is nanelijk ontworpen door Jan de Boer en mijzelf.

7. Ontwerp 13 W van Eritrea, Boek 1, artikel 708 :

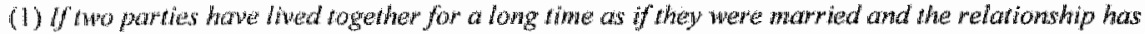

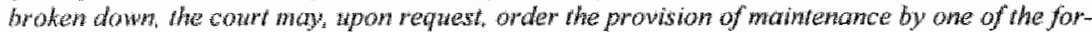
wer contibires to the ather forner cohabitee.

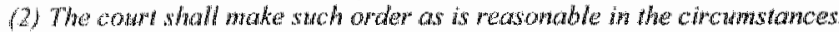

(3) The prowsions wh respect to the obligation to prowde mainenance by a former spouse are appopticable mutatis mutandis.

is Sthwer e. a. ar. n. 36, pp. 247.8.

Tekst van de ontwerphandsverorden ing, zoals bij de Staten van de Nederlandse Antillen en die wan Aruba is ingediend, Memorie wart Toehchting, afdeling 4. 
band leidt ertoe dat de alimentatieplicht wordt beperkt tot samenwoningsrelaties die zich kenmerken door een werdergaande onderlinge athankelijklid van de partners.

In het voorgestelde art. $408 \mathrm{~b}$ van het Antilliaans Burgerlijk Wetboek wordt echter geen verband gelegd tussen de tijdens de relatie ontstane levensverhouding en de situatie daama. In dat opzicht wijkt het af van de voorstellen van Minkenhof en Dawids, die beiden de eis van een causaal verband stellen. Zo lat het voorgestelde $408 \mathrm{~b}$ van het Antilliaanse BW de mogelijkheid open dat de rechter een onderhoudsverplichting vaststelt in een geval waarin de partners vijens de relatie economisch onafhankelijk van elkaar waren, maar waarin kort na de beëindiging van de relate een van de partners failliet gaat of ten gevolge van gezondheidsproblemen niet meer in staat is zichzelf te onderhouden. Een verlies van inkomen van een wan de vooma lige partners ten gevolge van een slechte gezondheid kan een reden zijn hem of haar financieel tegemoet te komen, maar deze onmogelijkheid on in het eigen onderhoud te voorzien heeft niets met de relatie te maken en behoort dan ook niet de verantwoordelijkheid te zijn van de andere partner. Ik verwacht niet dat de Antilliaanse rechter de bepaling op deze wijze zal interpreteren, maar ik acht het wenselijk dat de gronden voor de bevoegdheid van de rechter nader worden aangegeven. Uit de hiema te bespreken Canadese wetgeving blijkt dat een nadere afbakening wan de rechterlijke bevoegdheid op zichzelf goed denkbaar is, maar tevens dat er weinig overeenstemming is over de wijze waarop deze afbakening in de praktijk gestalte moet krijgen.

In de meerderheid van de Canadese provincies en "ferritories" is wettelijk geregeld in welke gevallen een partij aanspraak kan maken op alimentatie ten laste van degene met wie hij of zij samenwoont of samengewoond heeft. In deze gevallen verklaren al deze wettelijke regelingen de bepalingen die gelden voor (ex)echtgenoten van overeenkomstige toepassing. In Manitoba bestaat een alimentatieverplichting "indien een man en een vrouw, niet met elikaar gehuwd zijnde, ononderbroken gedurende een periode van niet minder dan vijf jaar hebben samengewoond in een relatie waarin de verzoeker woor het levensonderhoud in belangrijke mate van de ander afhankelijk is geweest en het verzoek wordt ingediend terwijl de man en vrouw nog samenwonen of bimnen een jaar na de beëindiging van de samenwoning, ${ }^{97}$ Nova. Scotia kent een alimentatieverplichting indien een man en een wrouw, niet met elkaar" gehuwd zijnde, gedurende een jaar als man en vrouw samenwonen'. 78 Daartegenover kent Quebec geen alimentatieverplichting voor ex-samenwonenden. Het ontbreken van een dergelijke bepaling is opmerkelijk, ondat deze deelstaat van alle Canadese deelstaten het hoogste percentage aan samenwonenden kent. ${ }^{79}$ Op grond van section 29 van de Ontario Family Law $\mathrm{Act},{ }^{80}$ is dezelfde onderhoudsverplichting die geldt voor echtgenoten ${ }^{81}$ ook van toepassing op een man en een vrouw of twee

Family Maintenance Act, R.S.M. 1987, c. F20, s, 4(1). where a man and a wowan, nol being married to each other, have cohabited continuously for a period of not less than five years in a relarionship in which the applicant has been swbstamially dependent upon the other for support. if an application under this Act is made whilst they are cohabithng or within ane year after they cease cohobiting...".

78 Fandy Maintenance Act, s. 2(1), "a mar and a woman who, wo being married to each other, live rogether as thusband ard wife for one year' online: hatp:/leg is acjinet.org'

79 M. Bailey, Law Commisston of Carada Contract (Personal Relationships), Ottawa, 1998, p. 64.

89 R.S.O. 1990 , c. F. 3, s. 29

81 Section 30: Every sponse has an obligation to provide support for hinself and herself and for the other spouse in accordance with need, to the extent wat he or she is capable of doing so. De doefen varn de alimentatieverplichting zijn in section $33(8)$ neergelegd: pecogwhison and compensation 
personen val hetzelfde gestacht die niet met elkaar zinn gehuwd en die met elkaar hebben samengewoond

(a) gedurende een ononderbroken periode van niet minder dan drie jaar, of

(b) in een relatie van enige bestendigheid, indien zij de biologische of adoptieve ouders zin van een kind. ${ }^{22}$

Samenwonen (cohabitation) wordt in section 1(1) van de Ontario Family Law Act wet gedefinieerd als: "samenwonen in een met het huwelijk op een lijn te stellen relatie" ("lo lwe logether in a conjugal ralationship"). Bij de interpretatie van de begrippen 'samenwoning' (cohabitarion) en 'met het huwelijk op een lijin te stellen relatie" (conjugal relationship) zjin de rechters twee verschillende richtingen opgegaan. Sommige rechters hebben vooral de nadruk gelegd op de economische verhouding tussen de partijen. Zo kon er volgens de rechter in Sioikiewicz w Filas ${ }^{83}$ geen sprake zijn van samenwoning in de zin van section 29 , tenzij de partners op dezelfde wijze als echtgenoten plegen te doen een onderhoudsverplichting op zich hadden genomen. ${ }^{84}$ Omdat beide partmers in Stoikicwicz economisch zelfstandig waren, was er volgens de rechter geen sprake zijn van samenwoning als bedoeld in section 29. Door veel andere rechters werd deze zuiver economische benadering te beperkt gevonden. $^{25} Z$ ij waren van oorcled dat onderzocht moet worden of de relatie in functioneel opzicht vergelijkbaar is met een huwelijk, Daarbij hebben sommige rechters het noodzakelijk gevonden om een checklist te hanteren van allerlei mogelijke functies wan het huwelijk zoals daar zijn op het gebied van het onderdak, de seksuele en persoonlijke relatie, het verrichten wan diensten, het sociale leven van de partners, de relatie tot de samenleving, het levensonderhoud, de eigendomssituatie en kinderen. ${ }^{87}$ Het is echter onhadbaar gebleken on in alle situaties een strikt onderscheid te maken tussen de economische verhouding en de andere functies van de samenwoning. In $R e$ Harris" and Godkewilsch ${ }^{88}$ vloeien deze factoren samen waar de rechter zijn oordeel dat de partijen samenwoonden in de zin van section 29 baseert op zijn bevindingen dat de vrouw economisch afhankelijk was van de man en dat deze afhankelijkheid bevorderd werd door de aard van hun verhouding, die zich kenmerkte door liefde en gezelschap.

Als volgens de rechter vaststaat dat de partijen samenwonen in de zin wan section 29 van de Family Law Act wordt doorgaans niet zwaar getild aan de andere door deze bepaling gestelde eisen. Als de partners gedurende drie jaar hebben samengewoond wordt die periode als ononderbroken aangemerkt, ook al hebben er feitelik onderbrekingen in de samenwoning plaatsgevonden, mits geen van beide partners de intentie had om de ralatie te beêindigen. ${ }^{89}$ Als de partijen samenwonen en

$\rightarrow$

of constribution to the relationship. the promotion of self-sufficiency, the equality of parental re-

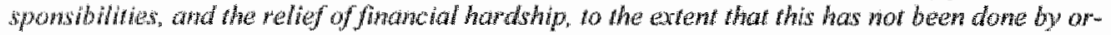
ders in relatian to Parts 1 and li of the Act (properiy readjus(menti).

(a) continususly for a period of not less than three years, or

(b) in a relarionship of some permanence, if they are the matural or adoptive parents of a child

8.7 (1978) 7 R.F.L. (2d) 366 (Ont. U. F.CL).

8. Hot. p. 369-370.

S5. Armstrong whompson (1979) 23 O.R. (2d) 421 (S. Ct.)

gis Re Feehan and Attwells (1979) 24 O.R. (2d) 248 (Co.Ct), p. 251; Sanderson v Russell (1979) 24

OR. (2d) $429(\mathrm{C} . \mathrm{A}$.

B. Molodowich "Pentimen (1980) IT R. F. L. (2d) (Ont. Distr. Ct.), Kurisko D.C.J., p. 381-2; Rowtley W Dimitrieff (1982) 36 O.R. (2d) 302 (Master).

4\% (1983) 41 O.R. (2d) 779 (Prow. Ct. Fan. Div.)

Bu Re Fechan and Atwells (1979) 24 O.R. (2d) 248 (Co.Ct); Sandersos w Russell (1979) 24 O.R. (2d) 429 (C.A.); Dicks v Zawitz (1979) 13 R.F.L. (2d) 179 (Ont. Prov. Ct). 
een gezamenlijk kind hebben wordt bovendien al snel aangenomen dat er sprake is van een relatie met enige bestendighed. In deze laatsta situatie geldt overigens niet de eis dat de partijen drie jaar hebben samengewoond. Een samenwoing van elf maanden is in dat geval al voldoende. 90 ảen geval werd zelfs een samemwoning van slechts zes weken voldoende geacht, aangezien de partijen tromwplamen hadden. ${ }^{91}$ Daarentegen werd geen relatie met enige bestendigheid aangenomen in een geval warin de partners wel gezamenlijk een kind hadden, maar waarin beiden een eigen huis hadden en financieel onafhankelijk van elkaar waren, terwijl de partners slechts zeer kort, in afwachting van het gereedkomen van de verbouwing van het huis wan de ander, hadden samengewoond.

De eerste benadering, waarin het criterium wordt gehanteerd of een partij economisch afhankelijk is van de andere, geeft de samenwonenden een zekere vrijheid om de vom van hun relatie te bepalen: kiezen zij ervoor om een invulling te geven aan hun relatie waardoor de ene partmer financieel afhankelijk wordt van de andere, dan heeft deze keuze gevolgen als zij uit elkaar gaan. Kiezen zij in hun relatie voor een onathankelijkheidsmodel, zoals de "vrije jongen-kostgangersrelatie", dan ontstaat de onderhoudsverplichting niet. Voor het antwoord op de vraag van welke relatievorm sprake is wordt niet alleen gekeken naar de bedoelingen van de partners, maar ook naar de wijze waarop de partners daadwerkelijk invulling geven aan hun relatie. De keuze van de partners weerspiegelt in wezen de keuze tussen het traditionele huwelijksmodel en het meer zelfstandige relatiemodel. ${ }^{94}$ Een dergelijke benadering sluit ook aan bij de bevindingen in het NISSO-onderzoek waaruit bleek dat ongehuwd samenwonenden zich duidelijk onderscheiden naar de bedoeling die zij met hun relatie voorstaan en naar de wijze waarop zij elkaar feitelijk onderhouden. ${ }^{95}$

Als blijkt dat de ene partner tijdens de relatie feitelijk onderhouden is door de andere, zou de rechter de bevoegdheid moeten hebben om na de beëindiging van de relatie op verzoek en ten behoeve van de partij die daarvoor in aanmerking komt, een onderhoudsvoorziening te treffen. Deze toekenning dient te geschieden onder dezelfde woorwaarden als van toepassing zijn op ex-echtgenoten. Er dient dan ook rekening te worden gehouden met factoren als de behoefte, draagkracht, en andere omstandigheden, zoals het gedrag van de eisende partij 95 . Om de hiervoor uiteengezette redenen zou ik de vaststelling van een onderhoudsplicht in dit soort gevallen willen beperken tot de situatie waarin sprake is wan economisch afhankelijkheid van de ene partij ten opzichte van de andere. Het is de formulering van Davids die deze door mij bepleite link tussen de vereiste levensverhouding en het aspect van cle economischo afhankelikheid goed tol uiting brengt.

Evenals de Nederlands-Antilliaanse bepaling bevatten de Canadese bepalingen een vereiste met betrekking tot de duur van de relatie. Uit het NISSO-onderzoek blijkt dat de duur van de relatie noch betrouwbare indicatie is voor de bedoeling van de partners, noch voor hun feitelijk handelen met betrekking tot de onderhouds-

Dowhen and Irwing(1978) 6 R.F.L. (2d) 242 (Ont. Prow. Ct).

- Labbe MCCHangh(1979) 23 OR (2d) 536 .

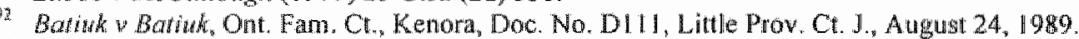

9. An Ansterdam 30 oktober 1974, NJ 1975, 259.

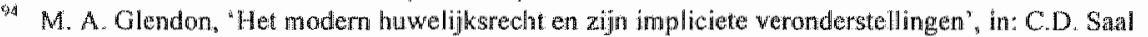
en C.J. Straver (red.) Sawenleven in mecrwowd, pp. 50.69 .

9. Suraver e.tak, n. $36, \mathrm{pp}, 128-130$.

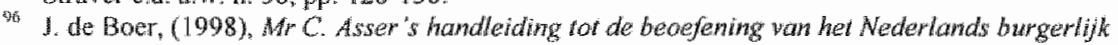
pecht, Personen-en fomilierecht, Tjeenk Willink, Deventer; $1998, \$ \$ 28-629$ 
plicht. ${ }^{97}$ Het opnemen van en dergelijke bepenking is daarom af te raden. Het hier bepleite verband tussen de levensverhouding en de economische afhamkelijkheid van de partmers is mijns inziens ean voldoende maatstaf voor de rechterlije vaststelling wan een onderhoudsplicht.

\section{De relewantie van het werzorgen of hebben verzorgd wan kinderen}

Section 9 van de Ontario Family law Act, die voor de rechterlijke bevoegdheid om aen onderhoudswoorziening to treffen de woorwarden stelt dat er emige permanentie is in de samenwoning en dat de partners een gezamenlijk kind hebben. zict op een situatie warin veelal ook sprake zal zijn van vorenbedoelde economische afhankelijklleid. ${ }^{5}$

Ook de twee Australische Territories New South Wales en Australian Capital Territory kennen regelingen die zich kenmerken door een speciale zorg voor de partner met kinderen. In New South Wales is de rechter bevoegd een onderhoudsvoorzlening te trefien ten behoeve van de partij die niet in stat is in de eigen levensbehoefte te voorzien, omdat hij of zij de zorg heeft van een uit de relatie met de wederpartij geboren kind of van een ander kind van de wederpartij. Het kind mag de leeftijd van twalf jaar niet hebben overschreden. In het geval van een gehandicapt kind wordt deze leefiijdsgrens bepaald op zestien jaar. ${ }^{99}$ De Domestic Relationships Act 1994 in het Australian Capital Territory ${ }^{100}$ bevat een vergelijkbare bepaling.

Het is de vrag of het hebben van de zorg voor een kind als zelfstandige eis in de wet moeten worden opgenomen. Welke de consequenties zijn van dit criterium hangt van veel factoren af, zoals de werkgelegenheid, de herscholingsmogelijkheden en de maatschappelijke voorzieningen ten behoeve van de verzorgende ouder. In New South Wales komt de niet-werzorgende ouder van een gehandicapt kind mijns inziens veel te gemakkelijk onder zijn of haar verplichtingen uit. Met het oog op de emancipatie lijkt het me voorts bepaald niet wenselijk dat de wetgewer kennelijk van de veronderstelling uitgaat dat een ouder erop achteruit gaat door voor de kinderen te moeten zorgen. Het is well realistisch om met de zorg woor kinderen rekening te houden, maar het is niet nodig om de zorg voor kinderen als zodanig als criterium in de wet op te nemen. Ook deze situatie wordt mijns inziens voldoende bestreken door de wettelijke cis wan een uit de levensverhouding tussen de partners voortvloeiende economische athankelijkheid. In de toelichting bij de wet als woorbeeld van een dergelijke situatie kan worden gewezen op het verzorgen van kinderen.

\section{Goven acuslwing bij gehuwden}

In de Cunadese wetgeving stat de gelijkstelling tussen gehuwden en ongehuwden contraal. De rechter is slechts bevoegd en onderhoudsregeling te treffen indien de parthers "als man en vrouw samenwonen". Deze gelijkstelling als uitgangspunt voor de bevoegdheid van de rechter verdient mijns inziens geen navolging. Ze leidt tot problomen als het gaat om paren van hetzelfde geslacht en houdt geen rekening met de wens wan het part om niet als gehuwd te worden behandeld. Terecht geeft een Commissie uit de Engelse vereniging van advocaten, die de mogelijkheden om de positie van samenwonenden te regelen recentelijk heeft onderzocht, de woorkeur aan de definite zoals deze voorkomt in de Donestic Relationship Act 1994 van de

Sociar e.an, a, n. 36, pp. 247-8

Sociaal en cultureel rapport 1998, hfsi 8.

w) Property Relationships Act 1984, No. 147, section 27(1)(a) zoals gewijzigd.

Ita Domestic Relationships Act 1994 "section 19 
Australische Capital Territores. Deze regeling voorzet in een mogelijke onderhoudsregeling in geval van:

A personal relationship (other than a legal marriage) between two odwis in which one provides personal of financial comminuent and swpport of a domestic nature for the material bertefir of the other. ${ }^{\text {Iot }}$

Ook bij dit criterium sluit het voorstal van Davids aan.

\section{Limitering}

In het voorstel van de Engelse advocatenvereniging, dat overigens geen officiele status heeft, is geopperd dat de alimentatieverplichting normal gesproken voor een pertode van chie jaat wanaf het moment van het uit elkaar gaan zou dienen te gelden. Voor een verlenging van de duur van de onderhoudsplicht zou slechts aanleiding kunnen bestaan in gevallen van extreme financiele behoefigheid. Dit voorstel is onleend aan section 9(1)(d) van de Family Luaw (Scotland) Act 1985. ${ }^{102}$ Mits ar geen kinderen zijn zal een onderhoudsverplichting van deze beperkte duur in de regel voldoende zijn om de economisch afhankelijke partner tegemoet te komen bij het inspelen op de financièle gevolgen van de beëindiging van de relatie.

Een andere manier om de onderhoudsplicht te beperken is het hanteren van specifieke doeleinden. Het gat hierbij in feite om een nadere precisering van het begrip behoefte. Een voorbeeld biedt de reeds genoende De Facto Relationships Act 1984 van New South Wales (Australiè) die het treffen van een onderhoudsregeling onder andere beperkt tot de situatie watrin de alimentatiebehoeftige moet zorgen voor een kind dat jonger is dan twaalf jaar. Deze regeling voorziet er voorts in dat, indien de alimentatiebehoeftige partner als gevolg van de wijze wasrop aan de relatie invulling werd gegeven niet in staat is om in zijn of haar eigen levensonderhoud te voorzien, de rechter een alimentatievoorziening kan treffen. Daartoe moet de rechter ervan overtuigd zijn dat de te treffen voorziening het vermogen van de alimentatiebehoevende om in zijn of haar levensonderhoud te voorzien zall vergroten, bijvoorbeeld door het de alimentiebehoevende mogelijk te maken een opleiding te gaan volgen. Meer in het algemeen wordt de eis gesteld dat de toekenning van de alimentatie redelijk is. ${ }^{103}$ Op grond van deze regeling is de rechter niet bevoegd een onderhoudsverplichting wast te stellen indien de alinentatiebehoevende ten gevolge van ziekte of gevorderde leeftijd niet is staat is in het eigen levensonderhoud te voorzien en deze problemen ook niet door een training of cursus kunnen worden werholpen.

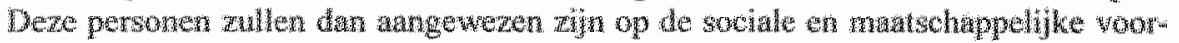
mangerar.

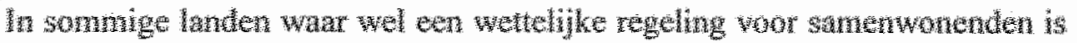

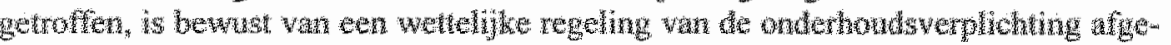

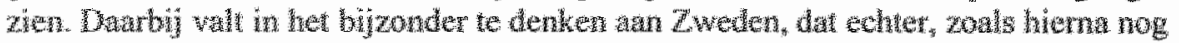

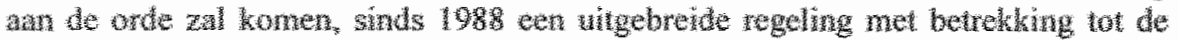

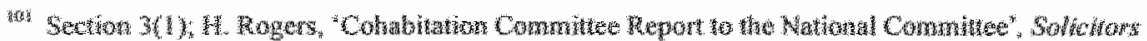

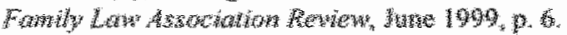

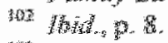

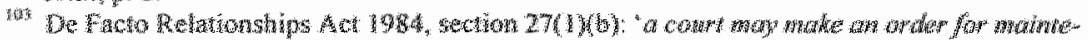

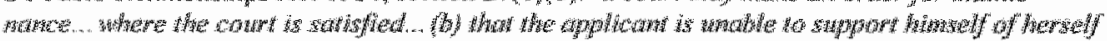

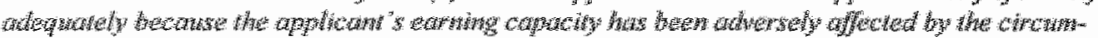

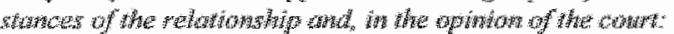

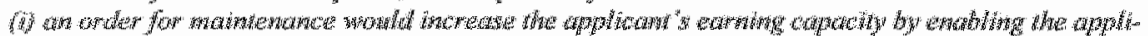

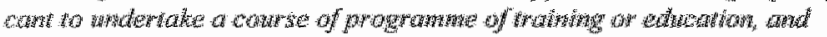

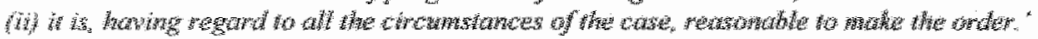


goederen van de (ex)partners kent. Dit verschil kan ten dele worden verklaard uit een verschil van uitgangspusten ten aanzien van partneralimentatie. Ten aanzien van echtgenoten onderling werd er in Zweden slechts in een zeer beperkt aantal gevallen tot het opleggen wan een alimentatievoorziening overgegaan. ${ }^{104}$ In Nederland is partneralimentatie, ondanks de Wet limitering alimentatie, echter nog steeds belangrijk. Uit een recente uitspraak van de Hoge Raad blijkt, zij het ten anzien wan een overgangsgeval, hoe terughoudend de Nederlandse rechter omgaat met de limiteringsregel. ${ }^{\text {los }}$ De reden voor deze terughoudendheid zall daarin gelegen zijn dat de maatschappelijke omstandigheden in Nederland nog steeds in de hand werken dat vrouwen regelmatig economisch afhankelijk zijn van hun mannelijke partners. ${ }^{106}$ Dezelfde factoren zijn echter van toepassing op ongehuwde ex-samenwoners.

Een andere verklaring voor de afwezigheid van een alimentatieregeling voor samenwonenden in het $Z$ weedse recht is gelegen in de regeling met betrekking tot goederen van samenwonenden. Deze heeft tot gevolg dat behoeftigheid van (een van) de partners na het verbreken van de relatie zich niet snel zal voordoen. Hierna zal deze goederenrechtelijke regeling onder de loep worden genomen.

\section{Aanbeveling}

Het Nederlands Burgerlijk Wetboek zou moeten voorzien in de bevoegdheid van de rechter om, ten laste van de ex-partner, alimentatie aan een ex-samenwoner toe te kennen, indien er sprake is van economische afhankelijkheid die het gevolg is van de wijze waarop de partners aan hun relatie invulling hebben gegeven. Mede in het licht van de voorgaande rechtsvergelijkende notities spreekt mij het voorstel van Davids nog het meest aan. Gelet op hetgeen hiervoor is vermeld over de twee verschillende interpretaties van de wetgeving in Ontario ben ik van mening voor het treffen van een onderhoudsregeling essentieel is dat er sprake is van financiele verstrengeling en lotsverbondenheid tussen de partners. Terecht wordt in het voorstel van Davids, anders clan de Canadese bepalingen, geen vergelijking gemaakt met gehuwden. Terecht legt het voorstel Davids, anders dan het Antilliaanse voorstel, een verband tussen de behoeftigheid en de wijze waarop de partners hun relatie hebben ingevuld. Terecht rept het voorstel Davids, anders dan de Australische bepalingen, niet van afhankelijkheid die het gevolg is van zorg voor de kinderen. Juist omdat het hier gaat om een vangnetbepaling, is het van belang om geen limitatieve wettelijke opsomming van verschillende mogelijke oorzaken van de economische afhankelijkheid in de wet op te nomen. Bovendien strookt het niet met het emancipatiebeleid van de regering om de opvoeding van kinderen in de wet aan te merken als een mogelijke oorzaak van

104 Swedish Marringe Code SFS 1987: 230 gewijzigd tot en met SFS 19941118, Part Three, Chapter 6. section 7: Following a divore, each spouse shall be vesponsible for his or her own stpport. If a contribution towards the waintentance of either spowse is needed for a transitional pertiod, that spowse shall be entitled to receive nawnenance paments from the of hem spouse on the basis of what is reasonable in wiew of the later "s ablity and or her circumstandes.

If either spotse has difficuly in supporting hinw or herself after a marriage of long duration has been diswolved or there ane other extraordinary reasons, what spowse shal be entitled to mainenance paymens from the other spouse for a longer period than is stated in the second paragraph.

105 HR 26 maart 1999. NJ 1999, 653-655 m. nt Wortmann onder 655; S.F. M. Wortnann, 'Gevolgen van de scheiding; voortduring wan het gezamenlijk gezag en limitering wan de alimentatie", in. Het fomitienecht in het perspectief wan de $21^{\text {xto }}$ eetw, VPFA Milleniumbundel, pp. 54-58.

tai Sociant en cultureel rapport 1998, hfist 8 (Emancipatie), pp. 222-228. 
economische behoeftigheid. De Nederlandse bepaling zou in een nieuwe afdeling van Titel 9 van boek 1 BW moeten worden opgenomen.

\section{De goederen van samenwonenden}

Er ontstat in principe geen gemeenschap van goederen tussen ongehuwd samenwonenden, tenzij er een overeenkomst met die strekking is gesloten of uit de omstandigheden van een stilzwijgende overeenkomst met betrekking tot de goederen blijkt. In de jaren zeventig is een aantal rechterlijke uitspraken gedaan waarbij de wettelijke gemeenschap van goederen van overeenkomstige toepassing is verklaurd op samenwonenden. Daarbij werd uitgegaan wan een analogie tussen de samenwoningsrelatie en het huwelijk. Dit deed bijwoorbeeld de rechtbank Groningen in een uitspraak van 5 november 1976 in een zaak waarin de ne partner beweerde een bedrag van 1. 5000 aan de andere te hebben geleend. De ontvangende partner, die het geld aan meubels had besteed, ontkende echter dat er sprake was van en lening. Naar het oordeel van de rechtbank bestond tussen de partijen een gemeenschap van goederen, hetgeen witsloot dat er sprake kon zijn van een lening. ${ }^{107}$

Deze ontwikkeling is snel afgekapt. Al gauw luidde de heersende leer dat er geen sprake kon zijn van een analoge toepassing van de wettelijke gemeenschap van goederen op samenwonenden. Zo oordeelde het Hof "s Gravenhage op 5 jamuari 1977 (Klusjesmanarrest) dat de man na het verbreken wan de samenleving geen recht had. op het huis waarin hij samen met de vrouw had gewoond. Het huis stond op de naam wan de vrouw en het Hof zag in de omstandigheden van het geval geen aanleiding voor het oordeel dat het huis in een tussen de parmers bestaande gemeenschap van goederen zou vallen. ${ }^{108}$ Hetzelfde ging op woor een tijdens een samenwoningsrelatie door de vrouw gekochte caravan, waarin de man na de verbreking van de relatie wilde wonen. ${ }^{109}$ Voorts werd ten aanzien van samenwonenden geen mede-eigendom aangenomen van een tijdens de relatie verkregen hond (bouvier). "10

De thans gevestigde rechtspraak werd ingezet met de uitspraak van de Hoge Raad van 16 januari 1987 (Bruinsma-Smit), waarin de Raad oordeelde dat "voor het antwoord op de vraag of tussen samenlevende partners enige gemeenschap van goederen bestaat, beslissend is wat $z i j$ dienaangaande - uitdrukkelijk of stilzwijgend zijn overeengekomen. "111 Volgens de Rrad had het Hof een onjuiste maatstaf aangelegd door te oordelen dat reeds op de grond dat de samenwonende partners ueder bepaalde uitgaven voor hun rekening namen, er geen sprake kon zijm van enige geneenschap tussen de samenwonenden. Naar het oordeel van de Raad stond de enkele omstandigheid dat de partners aparte rekeningen hadden en ieder van hun gezamenlijke kosten bepaalde uitgaven voor hun rekening namen, er nict aan in do wog dat krachtens een overeenkomst tussen hen gemeenschap van étn of meer vermo-

107 NJ 1977, 407; 110f "swravenhage 26 juni 1953, NJ 1954, 204; Rb Groningen 5 november 1976 . rolno, 42376 , beide besproken door Henriquez, a. w. 11.59, p. 11 en pp. $34-35$.

108. 1977,569 .

som Amsterdam 21 juli 1983, KO $1983,248$.

319 HR \& oktober 1982, NJ 1984, 2, m. nt. Brunner. De bouvier, die door de man was gekocht, had een auto-ongeluk veroonzakt. Hex slachtoffer kon geen schadevengoeding krijgen, ondat de man niet WA-werzekerd was De vrouw, die wel was werzekd en die het slachoffer tegemoet wide konden, deed een moedige, maar vergeefse poging on de rechter - en har verzekeraar - ervan te Dyertuigen dat er ten opzichie van de homd mede-eigendom was ontstak.

HI NH1987,912 mt. nt. Luijten. $0 . \% 3.3$. 
gensbestanddelen han hebben bestaan. Voorts sluit deze omstandigheid niet uit dat de samenwonevde parthers als deelgefoten tezamen gerechigd kunnen zjn geweest tot het tegoed op de rekening ten name van eén van beiden.

Op 26 mei 1989 oordeelde de Hoge Raad in de Kermisboedelzak dat het Hof "bovendicn onvoldoende inzicht" had "gegeven in zijn gedachtengang door, zonder nadere redengeving, woor een stillwiggende tot verrekening bij het einde van de samenwoning strekkende overeenkomst tussen de onderhavige partijen de eis te stellen dat her bestadin van de overeenkomst moet bliken uit de feiteljke financiejle uitwerking vath sen samenleving, bijvoorbeeld doordat zij al hun inkomsten hebben samengevoegd on hicunt al hun uitgaven te bekostigen. 112

Deze benadering van de Hoge Raad sluit goed aan bij de bevindingen van de socioloog Van der Avort. Deze identificeerde drie manieren waarop samenwonende parthers die beiden een eigen inkomen hebben, een financiele deling kunnen bewerkstelligen. In de eerste constructie worden beide inkomens op één gezamenlike rekening gestort. In de tweede constructie wordt een groot deel van beider inkomens op een of meer gezamenlijke rekeningen gestort, terwijl de rest gelijkellijk wordt verdeeld over ieders individuele rekeningen. In de derde constructie gaan de inkomens van de parthers naar individuele rekeningen en worden er afspraken gemaakt zodat elk nat draakkacht bijdragt aan gezamenlijke uitgaven en verder individueel beschikt over het min of meer gelijke restant. ${ }^{13}$

Uit de Kermisboedelzaak blijkt voorts dat de stilzwijgende overeenkomst soms de strekking kan hebben, niet om een gemeenschap van goederen in het leven Le roepen tussen de partijen, maat om een onderlinge verrekeningsplicht te bewerkstelligen in het geval van beëindiging van de relatie. Uit het arrest Smit-Brinsma blikt dat een beroep op een stilzwijgende overeenkomst niet noodzakelijkerwijs hoeft af te ketsen op de afwezigheid van een gezamenlijke rekening. Andersom geldt dat de aanwezigheid wan een gezamenlijke rekening niet altijd tot het bewijs zal kunnen strekken dat stilzwijgend tussen partijen is afgesproken dat een gemeenschap zal ontstaan.

De bedoeling van de partijen kan soms worden afgeleid uit de bron waaruit de middelen afkomstig zijn. Toen een bedrag van 1 . $272.672,45$ als schadevergoeding voor een door de matn in Australie opgelopen ongeluk was overgemaakt nat een op naan van beide partners staande rekening-courant, oordeelde het Hof Amsterdam dai de gezamenlijke rekening in deze omstandigheden geen bewijs opleverde voor een stilzwijgende overeenkomst op grond waarvan dit bedrag in de genteenschappelijke boedel zou moeten vallen. "It

Soms ziet de rechter aanleiding om de regels van redelijkheid en billijkheid toe te passen, zoals de rechtbank Assen in uitspraken van 8 maart 1983 en 7 februari 1984 (Cafetaria-arrest). ${ }^{15}$ In deze zakk oordeelde de rechtbank dat, indien zou komen vast to staan dat de man een thamciele bijdrage heeft geleverd aan de verwerving van het bedriffspand of de inventaris voor de cafetaria-onderneming van de vrouw, of aan het onroerend goed dat tijdens de relatie op nam van de vrouw werd

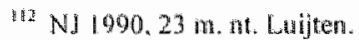

113 Van fle A wort, a.w. n. 43, p. 101

144 Hof Amsterdan 29 juni 1995. NJ 1997, 487 (Kont geding). Met betrekking tot gehuwden is scha-

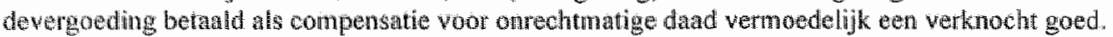

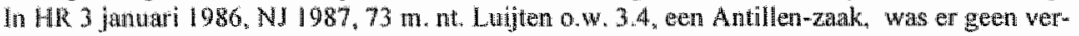

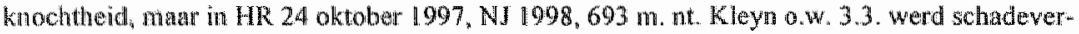
gooding dia an de urow was toegekend als varknocht goed arngemertht.

IIs NJ 1987.427. 
aangeschaft of aan de verbouwing darvan, de normen van redeligheid en billikheid meebrengen dat hij het nominale bedrag van deze inbreng terug moet krijgen. Naar hel oordeel van de rechtbank was er echter geen gemeenschap ontstan met betrekking tot de op aam van de vrouw gekochte woning waarin de partners vanaf 1976 hadden gewoond, welke woning door eiser zelf dan wel onder diens leiding was verbouwd. Noch het feit dat de woning werd betaald uit inkomsten uit het cafetariabedriff warin ook eiser meewerkte, noch het feit dat eiser eigen verdiensten als taxichauffeur bij de verwerving van de woning had ingebracht, was voor de rechtw bank aanleiding om eiser te laten meedelen in de waardestiging van het huis, nu het huis op nam wan de vrouw stond en dienaangaande geen uitdrukkelike overeen komst was gesloten. ${ }^{117}$ De rechtbank was woorts van oordeel dat de man geen ver" goeding toekwam voor de door hem in het bedrijf en in de verbouwing van het woonhuis verrichte arbeid, als de precieze omwang daarwan wastgesteld zou kunnen worden. Deze moest nat het oordeel van de rechtbank worden gezien als een "normale inspanning in het samenlevingsverband van partijen, die beide partijen, ook eiser, gedurende de periode van samenleving ten goede zijn gekomen." 113

Soms oordeelt de rechter dat een er beperkte gemeenschap is ontstaan. Op 27 mei 1977 deed de rechtbank Groningen uitspraak in een zaak watrin de partners vier maanden hadden samengewoond in een woning die op naain van de vrouw was gehuurd (Leekse samenwonersarrest). Vervolgens hadden de man en de vrow op nam van de vrouw een huis gekocht, waarvoor de man een derde wan de koopsom had betaald. De man eiste terugbetaling van deze geldsom. De wrouw wilde echter met een beroep op een volgens haar bestaande gemeenschap wan goederen de kosten die door haar ten aanzien van de huurwoning waren gemaakt bij de man in rekening brengen. De rechtbank overwoog dienaangaande :

'O. dat dit betekent, dat partijen ten aanzien van schulden, vorderingen en goederen, de gemeenschappelijke buishouding betreffende, moeten worden geacht door het gaan samenleven een gemeenschap te zijn aangegaan, terwijl het geheel of gedeelielijk uitsluiten dier beperkte gemeenschap als uitzondering aannemelijk moet worden genaakt;" 119

Op 13 december 1979 oordeelde het Hof "s-Gravenhage (in het Huurwoningarrest) dat de door de partners met het oog op de samenwoning gekochte goederen en het hurrecht van de woning waarin zij samen hadden gewoond in een beperkte gemeenschap van goederen vielen, "zij hel dat deze van beperkte aard is en niet te vergelijken is met de gemeenschap als bedoeld in art. 93 Boek $1 \mathrm{BW}$," 20 De desbetreffende goederen werden betadd ten laste van een op naam van de vrouw staande bankreke ning warop beide partijen hun salaris lieten overmaken en watrvan kosten van de gezamenlijke huishouding, de huur en duurzame gebruiksgoederen werden betaald. Wezenlijk voor het oordeel van het Hof dat de huurovereenkomst, hoewel deze op naany van de man was aangegaan, in de beperkte gemeenschajp viel, was dat de huurovereenkonst in verband met het samenwonen van de partners was gesloten. ${ }^{21}$ Het

16 Rb Assen 8 mant 1983 en 7 februari 1984, N1 $1987,427,0 . w .7$.

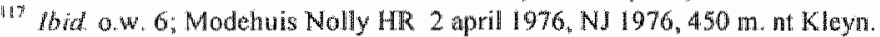

10 rbid, an 8 .

"Rv Groningen 27 mei $1977, \mathrm{NI} 1977,570, \mathrm{p} .1827 \mathrm{lk}$.

120 Hof "suravenhage 13 december 1979 , NJ 1980,556 ow. 3 .

(2) Hord, o.w. 3 . 
resultaat zou anders zijn geweest indien de humovereenkomst was gesloten vóndat de partijen de samenwoning op het oog hadden.

De redenering in deze twee uitspraken likit mij juist. Het is redelijk te veronderstellen dat als twee volwassenen gaan samenwonen, zij overeengekomen zijn om een bijdrage te leveren in de gewone hushoudelijke kosten, ieder naar zijn/haar mogelijkheden, witeraard tendj wordt bewezen dat er iets anders is afgesproken. Dit zou moeten gelden ook al zijn de partners niets overeenkomen over onderwerpen als de bekostiging van het levensonderhoud, de status van door de partners ingebrachte en stande de relatie verworven goederen, de gevolgen van het overlijden van een partner en de intenties van de partners bij het aangaan en hun verwachtingen over de toekomst van de relatie.

In de twee zojuitst besproken zaken ging het om de werdeling van baten of om en combinatie van baten en schulden. De regeling is auders indien het uitsluitend gaat om de verdeling van schulden tussen de ex-samenwonenden, zoals het geval was in een zaak waarover de rechtbank Rotterdam op 27 januari 1992 besiliste (Alkmaarse samenwonersarrest). In deze zaak waren de partners gaan samenwonen in een huurwoning die was toegewezen aan de vroww. Een half jaar daama hebben zij de relatie verbroken. Geduende de periode van samenwoning hadden de partijen schulden opgebouwd tot een bedrag van $11.5 .434,49$ an niet-betalde huur-, gas-, wateren electriciteitsrekeningen, ziekenfondspremie, telefoonrekeningen, belastingaanslagen en verdere heffingen, die allemaal ten name van de vrouw waren gesteld. De vrouw vorderde een bijdrage van de man, stellende dat er sprake was van een beperkte gemeenschap met betrekking tot de huishoudelijke kosten. Volgens de rechtbank geldt met betrekking tot schulden die samewhangen met de huisvesting in beginsel dat deze niet in enige gemeenschap van goederen vallen, tenzij anders is overeengekomen. ${ }^{122}$ Afgaande op de redenering in de eerder besproken zaken over baten had het mijns inziens echter voor de hand gelegen om een onderscheid te maken tussen, enerzijds, de goederen en schulden in het algemeen ten aanzien warwan mag worden aangenomen dat er geen afspraken zijn gemaakt en, anderzijds, de goederen en schulden die betrekking hebben op het voeren van de gemeenschappelijke huishouding. De stilzwijgende overeenkomst om in de huishoudelijke kosten te delen mag in mijn ogen worden verondersteld op grond van het enkele feit dat de partners samenwonen, uiteraard tenzij er bewijs is van het tegendeel. In de Rotterdamse zaak had de man overigens aangevoerd dat afgesproken was dat hij maandeliks aan de vrouw een vergoeding zou betalen als tegenprestatie voor het gebruik van de woning. Dit zou de bedoelde beperkte gemeenschap kunnen uitsiluiten.

In een geschil tussen een van de samenwoners en een derde biedt Boek $3 \mathrm{BW}$ weing uitkonst voor het aannemen van een gemeenschap die uitsluitend uit schulden bestaat. Dit blijkt uit een uitsprak van de rechtbank Zwolle van 4 augustus $1999^{123}$ die betrekking had op het na het verbreken wan de relatie voldoen van op de gezamenlijke huishouding betrekking hebbende schulden (achterstallige huurpenningen). Partij A, die door de kantonrechter was veroordeeld tot betaling van de huurpenningen. vorderde verdeling van de schulden met $B$, stellende dat deze in een gemeenschap vielen. Volgens de rechtbank kon er geen sprake zijn van een gemeenschap, aangezien er geen goederen maar slechts schulden waren. Volgens art. 3:166 lid $1 \mathrm{BW}$ is aen gemeenschap aanwezig wanneer een of meer goederen toebehoren aan twee of meer deelgenoten gezamenhik. Maar "goederen" zijn volgens art. 3:1

122. Rb Rotterlam 27 januari 1992, NJ 1993, 258, o.w. 4.2 .

23. FJR 2000 an. 3, p. 65 
BW alle zaken en wermogensrechten, niet schulden. De mogelijkheid on een verdeling van schulden te verkrijgen zou alleen aanwezig zijn wanneer er ook goederen waren te verdelen. ${ }^{124}$ Boek 6 , titell 1 afdeling $2 \mathrm{BW}$ over de verbondenheid van plirale schuldenaren zal meestal evenmin soulaas kunmen bieden, omdat deze titel slechts van toepassing is indien vaststaat dat een prestatie door twee of meer schuldenaren is verschuldigd. In de $\mathbb{Z}$ wolse zaak had partij $A$ ter onderbouwing van de stelling dat een gemeenschap bestond aangevoerd dat hij met B had samengewoond. Het argument dat de samenleving een gemeenschap in het leven roept komt neer op een beroep op de analogie tussen de samenwoning en het huwelijk. Zelfs als de rechtbank dit argument had aanvaard, had dit de eiser niet kunnen baten. Volgens bet huidige artikel 1:85 $\mathrm{BW}^{125}$ zijn beide echtgenoten "voor het geheel aansprakelijk" voor de "ten behoeve van de gewone gang van de huishouding aangegane verbintenissen'. Daaronder moeter de in het geding zijnde achterstallige huurpenningen zeker worden gerekend.

In het geval van verkrijging van roerende zaken die geen registergoederen zijn kan in sommige gevallen de ene partner geacht worden krachtens een stillzwijgende volmacht voor de andere te hebben verkregen. ${ }^{126}$ Dit kan bijvoorbeeld het geval zijn indien samenwonende partners beslissen om een auto te kopen voor gezamenlijk gebruik. De man koopt, met geld van hemzelf en van zijn partner, de auto. Op grond van art. 3:110 BW wordt de man geacht als lasthebber op te treden in eigen naam voor zijn opdrachtgever (de vrouw) met het gevolg dat de man, ofschoon hiij op het kentekenbewijs is vermeld als enige eigenaar, de auto mede voor de vrouw houdt. Volgens Moltmaker is deze regel van toepassing bij alle aankopen van gezamenlijke gebruiksvoorwerpen, ook indien een van de partner's niet meebetaalt. ${ }^{127}$

Een gemeenschap zal ontstaan wanneer de partijen een bepaald goed gemeenschappelijk hebben aangeschaft. Regelmatig kopen samenwonenden een huis op naan van beiden. 128

Bestaat tussen samenwonenden een geschil over de vraag wie van hen beiden eigenaar is wan een recht aan toonder of een zaak die geen registergoed is en kan geen van beiden zijn/haar recht op het goed bewijzen, dan wordt het goed op grond wan een analogische toepassing van art. 1:131 BW als gemeenschapsgoed aangemerkt, indien tussen de samenwonenden een gemeenschap bestaat die het goed kan omvatten. Bestaat er geen zodanige gemeenschap, dan wordt het goed geacht aan ieder der echtgenoten voor de helft toe te behoren. Door de werking van dit artikel kunnen partijen zich slechts beroepen op de exclusieve eigendom van een nietregister goed dat in gemeenschappelijk bezit is, indien zij kunnen bewijzen wie de eigenaar is. Het is daarom aan te raden dat de partners schriftelijk vaststellen wie wat heeft ingebracht. ${ }^{129}$

134 Op deze fenten waren de bepalingen in boek 6 , titel 1 afdeling 2 BW over de verbondenleid var plurale schuldenaren mogelik van toepassing mat in casu was hierover onvoldoende gesteld.

12 Indien het wetswootstel Wijziging wan de titels 6 en 8 wan Bock I van het Burgerljk Wethoek (rechten en pilchten echgenoten en geregistreerd partners) TK 1999-2000, 27 084, ingediend 17 april 2000, tot wet wordt verheven, kont an, 1:35 BW ve vervallen (Mw T, P. 9).

Ines $3: 61$ lid $1 \mathrm{BW}$

I.27. Moltmaker, De erfrechtelijke ern successierechtelijke aspecten wan het Samen-Leven", in Samen-Leven, p. 54 .

IIS Titell 7 afdeling 1 van boek $3 \mathrm{BW}$ is van toepassing.

ty9 Gr. van der Burght, "Enige opmerkingen over de wermogensmechtelige gevolgen van het ongeluw samenleven', in: Fref en recht buten echt, $\mathrm{p} .42$. 
Indien krachtens een van de bovengenoemde regelingen een beperkte gemeenschap is ontstaan, is er sprake van gebonden gemeerischap. ${ }^{130}$ De samenwonenden kunnen voor de duur van de samenleving niet vrij over hun aandeel in de zaak beschikken; toestemming wan de andere is hiertoe nodig. Bij beschikking over het goed na verbreking van de samenleving dient rekening te worden gehouden met de doeleinden van de gemeenschap, bijwoorbeeld als het huis was gelkocht voor de gemeenschappelijke kinderen. ${ }^{131}$

Tot slot bestaat er de mogelijkheid wan een actie uit ongerechtvaardigde verrijking. ${ }^{13.2}$ Hest zou te ver gaan om hier in detail in te gaan op de mogelijkheden die de actie van ongerechtvaardigde verrijking biedt ten aanzien van goederenrechtelijke geschillen tussen ex-samenwoners. ${ }^{133}$ Een groot woordeel van deze actie is dat de rechter in beginsel een grote vrijheid theeft bij het begroten van de schade. ${ }^{134}$ Uit de Canadese rechtspraktijk sinds $1980^{135}$ blijkt dat deze actie zodanig kan worden ontwikkeld dat zij uitkomst kan bieden in veel gevallen waaryoor in het Nederlandse recht op dit moment geen oplossing voorhanden is. Als het Nederlandse recht met betrekking tot de ongerechivaardigde verrijking een soortgelijke ontwikkeling had doorgemaakt als het Canadese recht, had ik mij tot deze actie kunnen beperken. Er zijn echter nog veel situaties waarin de Nederlandse actie uil ongerechtvaardigde verrijking geen bevredigende uitkomst biedt woor de goederenrechtelijke geschillen van samenwoners. lik bespreek slechts een paar van de relevante aspecten.

Bij een actie uit ongerechtwaardigde verrijking moet er sprake zijn van verarming aan de kant van de eisende partij tegenover verrijking van de gedaagde partij. In de zaak Baartman-Huijbers waarover de Hoge Raad op 11 april 1989 witspraak deed, vorderde een man van zijn voormalige echtgenote een financiële vergoeding ten bedrage van de door zijn activiteiten teweeggebrachte waardevermeerdering van haar woning. Het Hof had geoordeeld dat de man niet was 'verarmd', omdat "uit niets is gebleken dat Baartman de werkkracht die hij heeft aangewend ten behoeve van dat onroerend goed elders tegen betaling had kunnen en willen aanwenden., ${ }^{136}$ De HR vond hier geen blijk van een onjuist oordeel. Op grond van deze rechtspraak zal een klussende samenwoner niet met succes een actie uit ongerechtvaardigde verrijking kunnen instellen tenzij hij, om in het huis te kunnen klussen, een betaalde baan heeft afgewezen.

Voorts wordt de hoogte van de schadevergoeding bij een actie uit ongerechtvaardigde verrijking begrensd door de hoogte van de verrijking. Een typisch geschil tussen samenwoners betreft de waardevermeerdering van het huis van de ene partner ten gevolge van de inspanningen van de andere. Ook al is waarde van de inspanningen van partij $\mathrm{A}$ niet gelijk aan de waardevermeerdering van het huis wan partij $\mathrm{B}$, toch kan de vordering van A nooit hoger zijn dan het beloop van zijn verarming. Als

130 Art. 3:175lid $2 \mathrm{BW}$.

194 HR 20 decenber 1946, NJ 1947, 59 m. nt. E.M. Meijers, p. 38 lk. HR 9 mei 1952, NJ 1953, 563 m. nt Houwing. p. $918 \mathrm{k}$; Rb Zwolle 23 oktober 1979. NJ 1.981, 328; Rb Zwolle 8 april1982, RudW/KO 1982, 72.

132 Hof Arnhen 5 nowember 1974, NJ 1975, 378; Hof Amsterdam 7 mei 1975, NJ 1976, 110.

19: Bovendien vindt ex op 18-20 ok tober 2000 aan de Universiteit van Ansterdam een congres plaats over ongerechtwardige verrijking.

134 A.5. Hartkamp, Mr C. Asser's Mandleiding tor de Beofening wan het Nedertands Burgerlijk Rech, Verbintenissenrecht, Deel III, $10^{\text {dix }}$ druk, Tjeenk Willink, Deventer, 1998, 363 .

135 Petkus v Becker (1980) 117 DLR (3d) 257; Sorochan w Sorochon (1986) 29 DLR. (4th) 1; Pefer w Beh/ow (1993) loI DLR (4th) 62!.

13 HR 11 april 1986, NJ 19:86,622 m. nt wan der Grinten. 
A verarmd is met F1. 1.000, terwijl B verright is met F1. 10.000, kan A niet meer dan F1. 1.000 vorderen. Tenslotte kan in een actie voor onnechtwardige verrijking niet meer worden gevorderd dan het bedrag waarmee de ander is wertikk. Als A verarmd is met Fl. 10.000 en B verrijkt is met F1. 1.000 , kan A niet meer dan F1. 1.000 vordew ren. Deze "symmetrie" van veraming en verriking, die tot goede en rechtvaardige oplossingen in het algemene privaatrecht kan leiden, is niet toegesneden op de situa the van samenwoners. Zoals uit het hierna volgende zal blijken, geef ik de voorkeur an een meer "familierechtelijke" oplossing.

\section{Beschouwing}

Reeds uit de hiervoor vermelde beknopte weergave van de rechtspraak blikt dat het huidige recht in bepaalde gevallen tot zeer onbevredigende resultaten kan leiden. Onbevredigend is dat samenwonenden bij gebreke van afspraken niet kunnen worden verplicht de tijdens de relatie net betrekking tot de gezamenlijke huishouding genaakte schulden gelijkelijk te verdelen. Zeer onbewredigend is verder dat het recht geen oplossing biedt voor gevallen waarin tijdens de samenwoning op naam van een van de partners een huis is gekocht, terwijl onweersproken is dat beide partners hebben bijgedragen aan de koopprijs en/of aan de aflossing van de hypotheek. Op het moment van aankoop kan het opportum zujn om het huis op naam van één der partners te zetten, bijvoorbeeld indien deze partner een vaste baan heeft en de andere niet. Omstandigheden kunnen echter veranderen: de andere partij kan eveneens een baan krijgen, gelden erven of op andere wijze over middelen komen te beschikken en vervolgens alsnog (in hogere mate) bijdragen aan de financiering van het huls. Volgens de rechtspraak heeft dit alles geen invloed op de eigendom wan het huis. Deze blijft berusten bij de partner op wiens naam het huis is gekocht. De in zijn algemeenheid toe te juichen regel dat de titel tot een registergoed niet kan worden gewijzigd door informele afspraken of bijzondere omstandigheden, kan in de situatie van samenwonenden onrechtvaardig uitpakken. Indien de partners geen nadere regeling hebben getroffen is de partner die het huis niet op zijn of har naam heef staan slechts aangewezen op de mogelijkheid dat wit de omstandigheden zal blijken dat er sprake is van een stilzwijgende overeenkomst tot verrekening bij de beeindiging van de relatie, zoals het geval was in de Kermisboedelzaak. Eveneens acht ik het onbewredigend dat, indien de ene partner het op nam van de andere partner starande lhuis opkmapt of verbouwt, dit in het geheel geen rechten met betrekking tot het huis voor de eerstgenoemde partner in het leven roept, ongeacht de omwang van de werkzanheden en de hieraan verbonden kosten. Tot slot is er een tokortkoming die niet wit de Nederlandse rechtspraak over samenwoners blijkt, maar die wel in het kader van woomoemde probleemsituatie behoort te worden geplaatst. Ik theb het oog op de huisvrouw, die lange tijd het huishouden heeft verzorgd in het huis dat eigendom is wan haar partner en wellicht lange tijd de kinderen heeft verzorgd die uit har relatie met haar parther zijn geboren, maar die vervolgens, na verbreking van de relatie, met lege handen kan komen te staan.

\section{De stilzwigende overeenkomst in de situatie wan samenwonenden}

Hoewel het aannemen van een stilzwijgende owereenkomst in bepaalde situaties uitkomst kan bieden, acht ik deze mogelijkheid in het algemeen geen optimalle basis voor de regeling van de goederenrechtelijke verhouding tussen sarnenwonenden. Alles draait on de aard van de relatie. Als twee personen gaan samenwonen op basis 
van en affectieve relatie gedragen zij zich anders dan, bijwoorbeeld, een koper en een verkoper. De koper en verkoper zijn zich ervan bewust dat zij in een commereiale kader handelen en zullen zich min of meer bewust zijn van hun juridische positie. Het zal in ieder geval wederzijs geen beweemding wekken als zij ower een en ander afspraken maken en kennis nemen wan de mogelijke juridische gevolgen van hun haudelingen. Dit ligt allemal anders bij samenwonenden. Een relatie tussen samenwonenden is weinig doorzichtig, heeft veel verschillende miveaus - waarvan dat met betrekking tot financiele en zakelijke aangelegenhedien er slechts eén is - heeft een geschiedenis waaruit bepaalde aannames kunnen zijn ontstaan en is van onbepaalde duur. "Partners in een samenwoningsrelatie zijn geen zakenmensen die met "arm"s length dealing expliciet of impliciet afspraken maken. Veeleer gaat juist het tegenovergestudde op en zou een zakelijke benadering in de relatie van samenworenden als ongepast worden ervaren. Het inmemen van harde juridische standpunten zou het emotionele aspect van de relatie in gevar kumen brengen. Dit alles lijkt een verklaring voor het feit dat ar nog steeds een aanzienlijke groep - vamoedelijk de meerderheid - van samenwoners is die niet naar de notaris stapt on de regells van de samenleving wast te laten leggen. Op grond van dezelfde overwegingen ligt het weinig voor de hand om op zoek te gaan naar stilzwijgende overeenkomsten. Als er al sprake is van een stilzwijgende overeenkomst zall het moeilijk zall zijn de inhoud dararvan vast te stellen.

Uit het NISSO-onderzoek bleek dat opmerkelijk weinig paren een regeling hadden getroffen met betrekking tot de vermogens-en onderhoudsrechtelijke aspecten van een eventuele beèindiging wan de samenwoning. ${ }^{138}$ Door de onderzoekers werd in dit werband een aantal aandachtspunten aangestipt. Zo bleek wit het onderzoek dat de keuze van paren om in plaats van te trouwen ongehuwd te gaan samenwonen op tamelijk willekeurige en toevallige wijze geschiedt. ${ }^{139}$ Dit ligt wellicht in die zin woor de hand dat ongehuwd samenwonen niet is gebaseerd op het nemen van een aantal formelle stappen. Deze zelfde willekeurigheid, in de zin dat de keuze voor de relatievorm niet is gebaseerd op goede informatie over de juridische gevolgen, trof ook Scherf aan in haar in 1998 uitgevoerde onderzoek naar mensen die een geregistreend partnerschap aangaan. Doorgaans hadden de geregistreetd partners weinig kennis van de effecten van het sluiten wan een partnerschap; een derde van respondenten kon geen enkel juridische gevolg noemen. ${ }^{140}$ Ook naar aanleiding van het NISSO-ondarzok over samenwonenden is aandacht gevragd voor het gemis aan reflectie op ralatieverwikkeling en met name voor het feit dat men absoluut niet wil denken over ean mogelijke uiteengan. "Het ligt voor de hand dat de bereidheid onder ongehuwd samenwonenden om een regeling in de vorm van een samenlevingsovereenkomst te sluiten in de twee decennia sinds de uitvoering van het onderzoek is toegenomen. Uit de rechtspraak (bijvoorbeeld met betrekking tot de schulden) blijkt echter dat ongehuwd samenwonenden nog steeds vaak niets regelen. en dat dit vervalende gevolgen kan hebben.

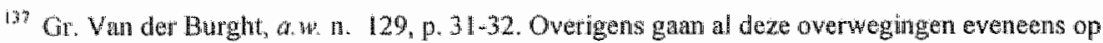
voor gehuwde koude uitshiters. Een wettelike regeling voor samenwoners zou dan ook van toepassing moeten zijn op paren die met koude uitsluiting gehtwd zijn of een partnerschap hebben laten registreren.

13: Straver ca. a. a. 36, pp. 150-162, 205-207.

Waid. p. 234.

wio Y. Scherf, Registered Partnership in the Nowerlands, A Quck Scan, WODC, Rijswijk, 1999, pp. 2426.

* Sil Sraver e.a, an n. 36, p. 234 . 
Ook wit het Engelse onderzoek van Stuart en Stevens blijkt dat weinig respondenten hadden nagedacht over de juridische gevolgen van samenwoning en dat velen (vooral vrouwen) onatugenam werden verrast toen zij vernamen dat het reeht geen juridische gevolgen hechte aan de samenwoning. Het ging daarbij wooral om het ontbreken wan wemmogensrechteljke gevolgen en gevolgen voor het ouderschap. ${ }^{142}$ Slechts weinigen hadden tijdens de relatie een advocaiat geraadpleegd, en slechts ongeveer de helft deed dit op het moment van uit elkaar gaan. ${ }^{143}$ Ewenals de Nederlandse hadden vele wan de Engelse respondenten misvattingen over hun juridische situatie. ${ }^{144}$

Het diffuse karakter van de relatie tussen samenwonenden lat zich goed illustreren aan de hand van voomoemde uitspraken van de rechtbank Assen in het Cafetaria-ondernemingarrest. In deze zaak exploiteerde de vrouw een cafetaria in een pand dat haar werd toebedeeld in het kader van een boedelscheiding na de echtscheiding nussen har en haar voomalige echtgenoot. Gedurende de dertien jaar dat de vrouw met haar nileuwe partner sanienwoonde, werkte de man soms fulltime, soms partime als chauffeur. Daamaast werkten de partners gezamenlijk in de cafetaria en hadden zij gezamenlijk het bedrijispand met woonhuis verbouwd. De kosten van deze verbonwing werden mede voldaan uit de inkomsten van de man als chauffeur. Voorts hadden zij met gebruikmaking van de uit de gezamenlije exploitatie van de cafetaria werkregen middelen een woning gekocht die zij gezamenlijk hadden verbouwd. Maar omdat het bedrijf en het woonhuis op naam van de vrouw stonden, had de man geen recht op de wardestijging wan de woning toen zij in 1981 - na een samenwoning van dertien jaar - uit elkaar gingen. Frappant is de volgende overweging van de rechtbank:

'De arbeid en vlijt, die eiser in het bedrijf geinvesteerd heeft, moeten gezien worden als een nomale bijarage aan her verdienen van de gemeenschappelijke kost, zeker in de periode, waarin eiser overigens geen inkomsten had en pp. dus geheel op de inkomsten wit het bedriff waren aangewezen om van te bestaan." 145

Als de investeringen en inspanningen als een normale bijdrage aan het verdienen van de gemeenschappelijke kost worden aangezien, komt het mij voor dat het zeer wenselijk is dat er in het recht een mogelijkheid bestaat om deze normale bijdrage te erkennen. De rechtbank identificeert - onbewust - het gedrag van de samenwonenden in deze zaak met het gedrag van gehuwden. Het is precies dit soort gedrag, het samen investeren en werken voor cen gezamenlijk project, zonder dat men zich op dat mow ment bewust is van de precieze juridische gevolgen hiervan, warvoor thet wettelijk stelsel van goederen is bedoeld. An Anders dan gehuwden worden samenwonenden geacht hun positie juridisch te regelen. Desalniettemin zijn het dezelfde factoren die

4. Smart ert Stevens, a.w, n. 45, p. 42 .

34: Smat en Stevens, a.w. T. 49, p. 41

iat Smart en Stevens, a.w. n. 45, pp. 41-42; R. Pickford, Fathers, Marriage and the Lam, London, FPSC/Josegh Rowntree Foundation, 1999.

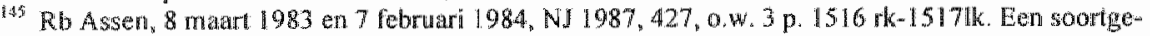
lijke relatie nar bedrijf en goederen, de priwe en werksfeer, en de gotderen en insjonningen wan de pathars naw verstrengeld waren trefin men ook in de Kernisbodelzak waarover de HR op 26 mei 1989 had geoordeeld. Een identieke redenering werd in 1975 door het Zweedse Hoogste Qc rechtshof loegepast: 1975 WJA 1. p. 298 in: Agell, a. W. n.61, pp. 196-197.

14, Wan Mourik, a. n. 5, p. 65; Van der Burght, 'De huishoudelijke echtgenoot behoort bij echt-

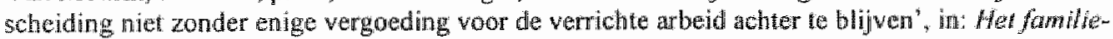

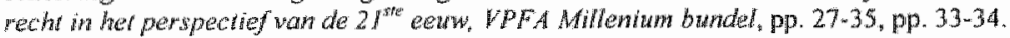




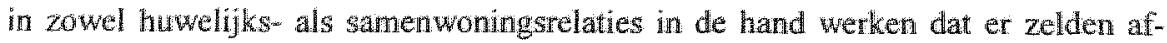
spraken worden gemaakt.

\section{Schulden die acrigegan zijn om de hishouding te woeren}

Uit voornoemde uitspraken van de rechtbank Rotterdam van 27 januari 1992 en van de rechtbank Zwolle van 4 atugustus 1999 blikkt dat de huidige wettelijke regelingen onvoldoende houvast bieden voor een verdeling van de schulden die ten behoeve van de huishouding zijn aangegaan. $\mathrm{K}$ acht het dan ook wenselijk dat er een wettelijke regeling komt, watin wordt vastge legd dat als twee personen samen gaan wonen, zij beiden, elk nar draagkracht jegens elkaar, verplicht zijn om bij te dragen in de met de gezamenlijke huishouding samenhangende kosten. ${ }^{147}$ IK geef aan een verdeling natar dragkracht de woorkeur boven een 50.50 verdeling. "Uit het onderzoek van Van der Avort blijkt dat de meeste paren kiezen voon een verdeling naar draagkrocht. ${ }^{149}$ Dit sluit goed axm bij art. 1:84 BW. De regeling zou in een nieuw lid van ant. 1:84 BW kunnen worden opgenomen. De bepaling zou van toepassing moeten zijn ongeacht de dur van de samenwoning. Het zou mogelijk moeten zijn om iets anders af te spreken.

\section{Het probleem van registergoederen}

Met betrekking tot niet-register goederen biedt het huidige recht in vele situaties uitkomst. Uit de hiervoor genoemde uitspraken van Hof "s-Gravenhage 5 januari 1997 (KJusjesmanarrest) en van de rechtbank Assen van 8 maart 1983 en 7 februari 1984 (Cafetaria-ondernemingarrest) blijkt dat deze zelfde flexibiliteit niet bestaat met betrekking tot registergoederen. Dit verschil werkt onrechtvaardigheden in de hand, nu het gezamenlijk huis meestal cle duurste aankoop zal zijn en de investeringen van de niet-eigenaar aanzienlijk kunmen zijn. Hierna zal ik betogen dat het noodzakelijk is or de register-en niet-register goederen van de samenwonenden aan dezelfde regeling te onderwerpen. Alvorens de mogelijkheden hiertoe te bespreken ga ik echter in op de motiveringen achter de huidige regeling.

\section{Het relatievribeid-argument onder de loep}

Zoals door" het Hof "s-Grawenhage in meergenoemd Klusjesmanarrest op 5 januari 1977 is overwogen en door wetenschappers is beaamd, ${ }^{150}$ komt de man en de vrouw relatievrijheid toe; anders gezegd: zij hebben het recht on de vorm van hun relatie te kiozen; het zou in strijd zijn met hum antonomie on aan hun relatie gevolgen te verbinden die zij bewnst hebben willen vermijden. In de woorden van het Hof: "Als partijen alls deze niet in het huwelijk treden maar gaan samenleven als waren zij gehuwd, doen zij een welbewuste kewze." Het Hof overwoog voorts dat evenmin zeker is, dat als de man en de viouw waren getrouwd, zij zouden hebben gekozen

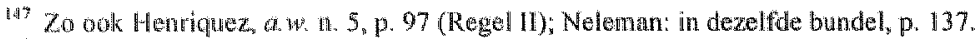

An Anders, Henriquez, in Twee mengen en het rech, pp. 50-51 wath hil de woorkeur uitspreek voor

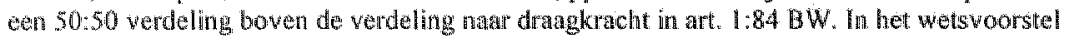
rechten ofit plichten van echgenoten en geregistreerd partners (TK 1999-2000, 27084 ) wordt de wableling naar dragk kracht gehatudhand.

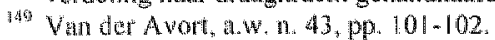

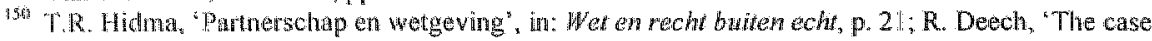
agnanst legal rocognition of cohabitation", (1980) I.C.L.Q.480; T. Lyon, "Towards a justification of property rights for cohbiftess". (1980) $130 \mathrm{New}$ Law Houmal 228.

13H Hof " 3 -Graventhge s jantari 1977 , NJ 1977,569 , p. $1826 \mathrm{~K}$. 
woor het wettelike stelsel wan gemeenschap van goederen; mogelijk waren zij dan getrouwd met koude uitsluiting.

Dit argument lag wel erg voor de hand in de zak walarover het Hof in deze zaak moest beshssem. De partien hadden, in de woorden van het Hof, beiden wen rime ontwikkeling en levenservaring. De man was toen omstreeks 48 , de vrouw omstreeks 40 jaar, beiden waren praktiserend arts, beiden waren gehuwd geweest, de man had uit zijn huwelijk vier of vijf kinderen, de urouw éen kind wit het hare." 15,3

Veel minder aantrekkelijk is dit argument wanneer bet zonder onderscheid op alle ongehuwd samenwonenden wordt toegepast. In de eerst plaats ondat niet alle samenwonende parmers de opleiding en levenservaring deelachtig is als het paar waarover het Hof had te oorclelen. Daarbij dient echter te worden angetekend dat uit het onderzoek van Van der Avort natar voren komt dat het met de opleiding en de maatschappelijke positie van de meeste samenwoners wel meevalt. Volgens Van der Avort komt ongehuwd samenwonen vooral voor op de midden en hogere sociale niveaus en bijna niet op de lagere niveaus. ${ }^{154}$ Maar dit gegeven betekent niet dat $z$ ij met de nodige informatie toegerust zijn.

Een keuze tussen huwelijk en geen huwelijk veronderstelt kennis over de gevolgen. Of deze kennis onder de betrokkenen aanwezig is mag sterk worden betwijfeld. In het algemeen wordt er blijkbaar van uitgegaan dat partijen die erwoor kiezen om samen te gaan wonen op de hoogte zijn van de verschillen in goederenrechtelijke en andere juridische juridische gevolgen van het huwelijk en buitenhuwelijkse relaties. Hierop duidt Advocaat-General Biegman-Hartogla in haar conclusie onder HR 26 mei 1989 met de opmerking: "partijen hebben nu eenmal verkozen geen huwelijk te sluiten, en dus ook - voor zover zij zich dit realiseerden - om buiten het huwelijksgoederenrecht te blijven. ${ }^{155}$ Als de partners zich al realiseren dat de regimes verschillen, is voorts van belang dat zij op de hoogte zijn van de inhoud van de verschillenden regelingen opdat er sprake kan zijn van en bewuste keuze. Empirisch onderzoek naar de bij samenwonenden aanwezige kennis laat zien dat de juridische veronderstellingen een feitelijke grondslag ontberen. Uit het NISSO-onderzoek blijkt dat in meer dan een derde van de onderzochte gevallen sprake was van misvattingen over de goederenrechtehjke situatie. In het bijzonder gingen veel paren ervan uit dat de partner die een niet-registergoed had betaald de eigenaar van dit goed was, daarbij het belang van de wraag aan wie het goed is geleverd niet beseffende. ${ }^{156}$ Deze bevindingen zijn bevestigd door de hiervoor vermelde onderzoeken van Smart en Stevens en Scherf. Het blijkt zeer riskant om een beleid te baseren op de vermeencle bij de partners anwezige juridische kennis.

Een mogehike steun woot het autonomie-relatievrijheid argument zou kuinen worden gezocht in het gegeven dat samenwonenden in de praktijk niet veel belangstelling blijken te hebben woor een regeling van de vemogensrechtelijke gevolgen wan hun relatie. Uit het NISSO-onderzok blijkt dat de meeste respondenten geen onderlinge regeling met betrekking tot de goederen hadden gemaakt. Vrijwel geen enkel par had een regeling getroffen voor het geval het uit elkaar zou gaan, ${ }^{\text {st }}$ en geen enkele paar noemde het ontbreken van een scheidingsregeling als een knel-

4sz Hof suravenhage 5 januari $1977, \mathrm{NH} 197 \%, 569, \mathrm{p} .1826 \mathrm{k}$ (voel)-rk(hoofd).

is? Fof" s-Gravenhage januari 1977 , N 1977,569, p. 1826k-rk

is Wan der Avort, a. n. 43, hist 7 .

15.5 HR 26 mei 1989 . NJ 1990,23 AG Biegman Hartogh nr. 3.I.

Strover e. a., a. w. n. 36, p. 185, 206, bilage III, tabel is.

15. Sirawer e. a. a.w. ก. 36, pp. 186,228. 
punt. ${ }^{\text {Is: }}$ De paren in het MISSO-onderzoek woonden nog samen. In het onderzoek van Smart en Stevens, dat over ex-samenwonende parthers ging, vonden sommige responderten - vooral vrouwen - het jammer dat zij miets hadden geregeld en dat er geen juridische bescherming was. ${ }^{159}$ De intrinsieke warde wan deze gegevens mag betrekkelijk zijn, mat het verschil in reacties op dit punt is opmerkelijk. De meningen van de betrokkenen over de vraag of een regeling wel of niet wenselijk is zal sterlf worden beínwloed door de positie waarin zij verkeren. Wonen de partmers nog samen en gaat het goed met de relatie, zullen zij weinig voelen voor een scheidingsregelmg. Na verbreking van de relatie kan één partij teleurgesteld en de andere opgelucht zijn dat er geen scheidingsregeling is. Kortom, de houding van betrokkenen ten opzichte van de wenselijkheid van een scheidingsregeling wordt sterk beinvloed door de positie van de spreker op dat moment, en geeft ons geen objectieve indicatie over de wenselikheid van een regeling van de situatie van samenwonenden bij beeindiging van de relatie.

De opvating dat de vrijheid van de partijen om de vorm en inhoud wan hun relatie te kjezen niet mag worden ingeperkt, veronderstelt dat alle samenwonende parthers zich bewust tegen het huwelijk hebben gekeerd. In werkelijkeid is dit sleclits voor een deel waar. ${ }^{60}$ De redenen waarom mensen samenwonen in de plaats van te huwer zijn uiteenlopend. In dit verband valt te wijzen op:

at. het proethuwelijk: de partners kijken de kat uit de boom alvorens zich aan elkaar te binden;

b. de partners hebben beslist zich niet te binden;

c. de partmers voelen zich al gebonden en beschouwen het huwelijk als overbodig;

d. de partners voelen zich aan elkaar verbonden, maar hebben principiele bezwaar tagen Het huwelijk;

e. de partners willen om economische redenen niet trouwen (bijwoorbeeld vanwege verlies wan pensioenrechten);

f. de partners kunnen niet trouwen, omdat éen van hen nog getrouwd is. 161

Voorts is het mogelijk dat de partijen helemaal geen redenen hebben om niet te huwen, maar dat zij gewoon zijn begonnen om samen te wonen zonder hierover nagedacht te hebben of hierover stelling te hebben ingenomen. Onderzoekers in Zweden en de Verenigde Staten hebben geconcludeerd dat samenwoning slechts zelden het gevolg is van een weloverwogen keuze. ${ }^{162}$

Met betrekking tot de partners in categorieën a) en b) en d) zou het bezwaarlijk kwmen zijn on ze als gehuwden te behandelen. De tot deze categorieen behorende partners hebben inderdaad bewust van het huwelijk afgezien. Voor wat de andere categoriedn betreft lijkt het me niet zonder meer onjuist om de partners als gehtuwden te behandelen. Een gelijkstelling met gehuwden zou niet ongepast zijn voor partners behorende tot de categorieen (c) en (f). Voor wat de partners behorende tol categorie (d) betreft zou een gelijkstelling met het huwelijk onjuist zijn, ondat zij dit immers afwijzen, mar daarmee is niet gezegd dat een andere vorm wan wettelijke erkenning wan hun gebondenheid ongepast zou zijn. Categorie (e) is ingewikkeld,

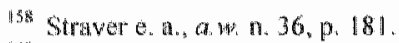

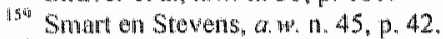

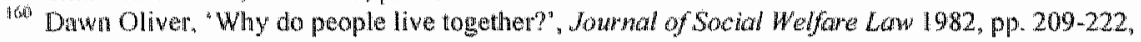
1.. 210 .

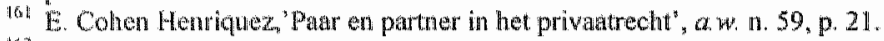

I: G.G. Blumberg, "Cohabitation Without Marriage: A Different Perspective" (19\%1) 28 U.C.L.A.L Rev, II25, 1134-6, 1167-70.
} 
want de economische redenen die de hiertoe behorende partnars hebben om niet te trowwen kunnen zeer urteenlopend zujn. Het is niet de bedoeling dat een partner van twee walletjes kan eten door zich te beroepen op twee met elkaar in strijd zijnde rechten. ${ }^{163}$ Indien een persoon beroep doet op twee verschillende rechten moet in de eerste plaats worden bekeken of de twee rechten werkelijk net elkar tegenstrijdig zin. In de tweede plats moet bekeken worden van welke van de twee walletjes nen wel mag eten. Dat men er bepaalde fiscale voordelen heef door niet te trouwen betekent bijvoorbeeld nog niet zonder meer dat samenwonenden moeten worden onderworpen aan een nadelige successierechtelijke regeling. ${ }^{164}$ De conclusie die moet worden getrokken wit het verschil tussen, an de ene kant, partners behorende tot de categorien (a), (b) en (d) en, aan de andere kant, paren behorende tot de categorieen (c), (f) en mogellik (e), is dat het bij een wettelijke regeling van de rechtspositie van samenwonenden noodzakeljk is te onderscheiden naar paren die het huwelijk weloverwogen hebben afgewezen, paren die in het geheel niet over deze keuze hebben nagedacht en alle paren die zich ergens tussen deze twee extremen bevinden. Als men woor een wettelijke regeling kiest, moeten de partmers het recht krijgen om ervoor te kiezen dat het wettelijk regime niet op hen van toepassing zal worden verklaard. Dit strookt met de bevinding van Smart en Stevens dat paren die de sterkste band hadden en dus de meest geschikt leken voor een huwelijksachtige regeling, de grootste ideologische weerstand tegen het huwelyjk bleken te hebben. ${ }^{165}$ Voor atn aantal van de door Smart en Stevens onderzochte relaties bleek een huwelijkachtige regeling in principe ongeschikt, ondat de motivering van de partners om niet te trouwen geheel was terug te voeren op het voorkomen van rompslomp bij het uiteengaan. Deze personen waren niet tegen het huwelijk als zodanig, maar hadden twijfels of de partner met wie zij samenwoonden wel de ware was. Desalniettemin vroegen de onderzoeksters zich af of ook in deze situatie een regeling niet op haar plaats zou zijn: naamate het samenwonen langer had geduurd of in de gevallen waarin er sprake was van kinderen, werkeerde de wrouw bij de beẻindiging wan de relatie vaak in een nadelige positie. ${ }^{166}$

Als men spreekt over paren die het huwelijk afwijzen, wordt ervan uitgegaan dat men te maken heeft met partners die het eens zijn over de vorm en inhoud wan hun relatie. Deze wooronderstelling gaat echter zeker niet voor alle samenwonende partners op. Bij sommige paren is immers weinig besproken (zoals bleek uit de rechtspraak over de verdeling van schulden met betrekking tot de gezamenlijke huishouding); soms hebben de man en de vrouw uiteanlopende wensen over de ontwikkeling van hun relatie.

Het 'respect" voor de 'relatievrijheid' wordt in deze mate alleen in thet prim vaatrecht aangetroffen. In het publiekrecht wordt darentegen wolop van een gelijkstelling met gehuwdern uitgegaan. Uit de rechtspraak komt regelmatig naar voren dat partijen het onbegrijpelijk vinden dat zif voor de toekenning van bijstand als een economische eenheid worden aangemerkt, maar dat deze economische verstrengeling in het priwatrecht nanwelijks erkenning vindt. 167

$16.40 f$ " Gravenhage 5 januari 1977 , NJ 1977, 569, p. $1826 \mathrm{lk}$.

104 I.K. Molitinaker, a.w. a. 127, p. 57

165 Smart en Stevens;

is Smart en Stevens, a. w. n. $45, \mathrm{p} .48$.

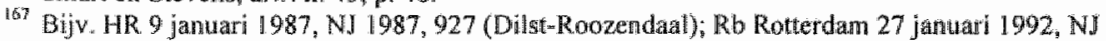
$1993,258$. 
Zelfs met betrekking tot partners die het huwelijk bewust hebben afgewezen valt er op het argument van de relatievrijheid wat af te dingen: zij hebben er weliswaar voor gekozen om geen huwelijk aan te gaan, maar het is nog maar de vraag of zij ook een minder vergaande regeling zouden afwijzen. Het slluiten van het huwelijk roept vele, verschillende verplichtingen in het leven; dat een paar het huwelijk afwijst wil nog niet zeggen dat het paar alle verplichtingen zou afwijzen. De NISSOonderzoekers constateerden dat het, juist omdat het huwelijk zoveel facetten heeft, weinig zinwol was om de paren te vragen waarom zij niet getrouwd waren. ${ }^{168}$ Dit gegeven is relevant, ondat bij de regeling van de goederenrechtelijke relatie tussen samenwonenden de keuze niet simpelweg behoeft te liggen tussen gelijkstelling met het huwelijk of niet. Door juristen is de relatievrijheid vooral gezien als een argument om samenwonende partners niet als gehuwden te behandelen. Het ligt echter veel meer voor de hand om na te gaan of voor de speciale situatie van samenwonenden niet een wettelijke tussenworm, tussen de zwart-wit-keuze van wel of geen huwelijk, zou moeten worden ingevoerd.

Er is nog steeds alle reden om de relatievrijheid - het recht om keuzes te maken over de invulling van de relatie - te handhaven. De noodzaak om de relatievrijheid te respecteren is door sociologisch onderzoek uitvoerig gestaafd. De vraag is echter of de juridische reactie hierop - de jurdische vertaling van de relatievrijheid niet meer genuanceerd zou moeten zijn. In het verleden heeft men zich vooral bezig gehouden met een keuze voor aansluiting bij het hwwelijk of helemaal geen regeling. Aan de conclusie dat een palar woor de 'relatievrijheid' heeft gekozen wordt de consequentie verbonden dat het paar het maar zelf moet regelen. Deze gepolariseerde benadering lijkt goed aan te sluiten bij een relaties die gekenmerkt worden door een streven naar individualliteit met een grote mate van vrijblijvendheid. Zo hebben verschillende sociologen gewezen op een ontwikkeling in de samenleving, die zich erdoor kenmerkt dat mensen steeds meer kiezen voor individualiteit en alle bindingen negeren. ${ }^{169}$ De sterke tendens naar individualiteit is door Van der Avort als volgt verwoord:

"In deze visie verliezen primaire verbanden veel van hun betekenis. Relaties worden slechts aangegaan ter bevrediging van individuele behoeften. Men stelt zich vrijblijvend op, weert verplichtingen en verantwoordelijken zoveel mogelijk. Het primaat wan individualiteit hindert een werkelijke betrokkenheid tot de ander. Inspanning en inzet voor de relatie zijn beperkt. Aandacht en zorg voor de ander mogen de persoonlijke ontplooiing niet in de weg staan. Individualisering in primaire relaties zou afbreuk doen aan de solidariteit tussen partners; dit proces bewerkstelligt onverschilligheid. Allerlei verschuivingen die zich in de afgelopen twee decennia hebben voorgedaan worden geïnterpreteerd als uiting van deze cultuur van vrijblijvendheid. ${ }^{170}$

De keuze tussen binding en individualiteit vindt in het privaatrecht zijn weerspiegeling in de keuze tussen huwelijk en geen huwelijk. Deze tegenstelling is mijns inzlens te zwart-wit. Zij houdt geen rekening met de ook voor het privaatrecht rele-

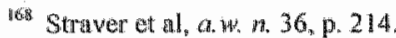

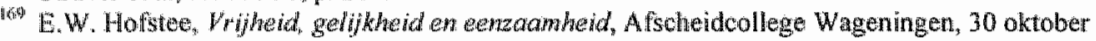
1980

17t Van der Avort, a. w. n. 43, pp. 287.288 
vante analyse van de socioloog Amo van der Avort, die de typische samemwoningsrelatie beschrijt als een proces van onderhandeling, waabu de partijen whever mar cen evenwich twssen binding en individualite it war van vriblijvendheid geen sprake is. ${ }^{171}$ Volgens deze analyse kenmerkt de moderne persoonlijke relatie zich niet of door individualiteit of door binding, mar bestal de relatie wit een communcatieproces waarbij het paar op zoek gaat naar een combinatie van individualiteit en binding. Van der Avort legt als volgt uit.

"Het specifiek eigen karakter van explicitering blijkt echter niet zozeer uit de afbrokkeling van traditionele structuren en gedragsvoorschriften of wit de gelijktijdige individualisering in primaire relaties, maan ligt dieper. Zoals eerder beschreven drukt het uit dat mensen gaan reflecteren over aspecten van hun relatie die voorheen vanzelfsprekend waren; dat zij zich bewust worden van de structume wan hun relatie en de gedragsregulering erin. Deze verandering van de individuele mentale instelling tegenover zichzelf en tegenover relatievorming in de primaire levensfeer vormt de eigenlijke kern van de verschuivingen van de laatste wee decennia. Deze explicitering brengt met zich mee dat onderlinge verhoudingen steeds uitdrukkelijker geregeld moeten worden; er zijn meer bewuste stappen nodig on een relatie in goede banen te leiden. Het fundament van een intieme relatie wordt niet stilzwijgend gelegd. Het verloop van interacties vertoont steeds minder automatismen. De partners moeten witdrukkelijker en bewuster met elkaar in de slag om hun onderlinge verhoudingen te regelen, hun posities af te bakenen en hun gedrag op elkaar af te stemmen. Het volle gewicht van de inspanning die in geexpliciteerde relaties moet worden geleverd kont te liggen op de procedures om een relatie te construeren en naar de inzichten van beide partners te modelleren. Hierbij is van vrijblijvendheid nauwelijks sprake. Inderdaad bestaat er momenteel meer vrijheid om te bepalen welke bepalingen de relatie zullen beheersen en hoe de onderlinge verhoudingen tussen de partners er uit zullen zien. Maar de weg waarlangs dit geschiedt is geplaveid met strikte eisen en voorschriften voor de onderlinge communicatie; het vraagt zelfinzicht, een besef van eigen verlangens, van die van de ander, en inzicht in de gevolgen van bepalde handelingen en van bevrediging van bepalde behoeften. 172

Het is voor een jurist niet gemakkelijk on met sociologische gegevens om to gaan. De explicitering waar Van der Avort op wijst, heef in de gemiddelde sancenwoningsrelatie niet geleid tot een explicitering van de voor de privatist interessante aspecten, zoals de verdeling van de middelen en het nakomen van de onderhoudsverplichting. Als ar al sprake is van een dergelijke explicitering laidt deze nog niet noodzakelijkerwijs tot vastlegging van de wederzijdse verplichtingen in een voorat:gaand aan de samenwoning afgesloten notarieel contract, maar krigt zij veeleer gestalte in een proces van woorturende onderhandeling gedurende de relatie. Toch meen ik dat er in de conclusies van Van der Avort een belangrijke boodschap zit die de jurist zou moeten uitdagen om aan samenwoners een kader te bieden warin de

(*) Bid, pp, 288-290.

the ibid pp. $298-290$. 
combinatie van binding en ind wduliteit beter tot withukking kom dan tu het geval is. Dit is icts anders dan de huidige regelng watrin de jurist utgaat van en polarisale usser binding (by het hwelik) en individualiteit (bil samerwoning), welke tegenstulling anderding is voor de vooronderstelling dat er zonder tegenbewijs geen sprake is van binding.

Bij deze discussie moet niet worden vergeten dat reeds in het huidige recht mbrew word gemakk op de relatievrijheid, door de toepassing van het beginsel van de redwhklyeid en billikheid en door het anmemen van stilzwigende overeenkomsten. Men kan er bijwoorbeeld gevoeglik wan witgan dat de man in de Kemisboedelzak noot stizwijgend of anderszins de bedoeling heeft gehad om het vermogen net de vrouw te verdelen. Toch werd hem de verphichting opgelegd om de waardesijging met haar te verrekenen. Voor wat de niet-registergoederen betreft is er reeds ean sastal instrumenten om gemeenschapsvermogen aan te nemen (artt. 3:110 BW on art. 1:131 BW). Deze regelingen kumen de werkelijke bedoelingen van de partijen doorkrusen. Met name de werking van de stilzwijgende overeenkomst en de toepassing van de redelikkheid en billikheid lijken niet bepaald bevorderlijk om de mdividuele kewzes yan de partijen te bevorderen, nu de werking ervan op voorhand onvoorspelbaar is. Daarentegen zouden de individuele keuzes van de partijen beter kunnen worden gerespecteerd door een wettelijke bepaling op te nemen op grond warvan door middel van een contractuele beding afwijking van de te treffen wettelike regeling mogelijk zou zijn.

\section{Mogelifke oplossingen}

In Engeland is er de laatste tijd veel discussie over een mogelijke vermogensrechtelijke constructie voor samenwoners. In Engeland zijn samenwoners aangewezen op de toepassing van de trust. Een trust ontstaat wanneer de partners de bedoeling hebben on de goederen in gemeenschap te houden. De trust heeft in vergelijking met de Wederlandse stilzwijgende overeenkomst onder andere het voordeel dat deze ook van toepassing kan zijn op registergoederen, mits de intentie van de partners hierop is gericht. Wel wordt voorzien in de nodige derdenbescherming.

Van een trust in de hier bedoelde zin is slechts sprake indien een gemeenschappelijke bedoeling van de partners tot het ontstaan hiervan kan worden bewezen. Zo ontstond er tussen mewrouw en meneer Burns, die negentien jaar ongehuwd samenwoonden, in die tijd een huis kochten en verbouwden en alle middelen in éen gemeenschappelijke pot deden, geen gemeenschap wan goederen. ${ }^{173}$ Ten gevolge van het ontbreken van het hiervoor genoemde bewijs kon mevrouw Burns na negention jaar samenwoning en na twee künderen te hebben gebaard en opgevoed, niets van de goederen claimen. Dit wordt door velen als onbevredigend ervarem. ${ }^{174}$

De Law Commission houdt zich momenteel bezig met de voorbereiding van een voorontwerp waarin de goederenrechtelijke relatie van 'homesharers' wordt geregeld. De bedoeling is een regeling te treffen voor iedereen die samenwoont, behalve indien de samenwoning geschiedt in de relatie van huurder-verhuurder, kostganger of in het kader van andere commerciele verhoudingen. Het tapport van de Law Commission wordt in het voorjaar 2001 verwacht.

173 Bums $v$ Burns [19841 FLR 216 (CA).

174 H. Rogers, a.m. n. 101, p. 5; A. Barlow, C. Lind, A Matter of Trust: the Allocation of Rights in the Family Home', Legal Sindies' 1999 Vol. 19 No. 4, pp. 468-488. 
In Engeland bestaat veel belangstelling woor de Australische bepalingen op dil gebled. ${ }^{175}$ Op grond van de De Facto Relationships Act 1984 heef de rechter in New South Wales de bevoegdheid om na de beeindiging wan een nader wettelijk onschreven samenwoningstelatie, ${ }^{176}$ een ex-samenwoner te bevelen goederen aan de voomalige partner te geven, of om goederen te verkopen en de opbrengst hiervan met de voormalige partner te delen, dan wel een geldsom aan de voormalige partner te betalen. De rechter moet daarbij rekening houden met de financièle of nietfinanciële bijdragen van partijen ter verwerving, behoud of verbetering van de aan een van de partijen of aan beiden toekomende goederen en met de bijdragen van partijen terzake van het verkrijgen en het beheer van de financiele middelen van een van de partijen of beiden. Voorts moet de rechter rekening houden met de door alk der partijen geleverde bijdrage tot elkaars welzijn en het welzijn van het gezin, wataronder ook de bijdrage als huishond(st)er of ouder moet worden verstan. Onder gezin moet worden verstaan de partijen tot de relatie en een gemeenschappelijk kind of een kind dat door een of beide van de partijen in de gezamenlijke huishouding is opgenomen. ${ }^{177}$ Een vergelijkbare bewoegdheid is te vinden in section 1.5 van de Domestic Relationships Act 1994 van het Australian Capital Territory. In deze bepaling wordt meer specifiek dan in de New South Wales wet aangegeven welke omstandigheden door de rechter in overweging moeten worden genomen, te weten: de duur en de aard van de relatie, de inkomens, de goederen en de financiéle middelen van elke partij, de lichamelijke en geestelijke geschiktheid van elke partij voor passende betaalde arbeid, de financiële behoeften en verplichtingen van elke partij en andere onstandigheden die de rechter relevant acht. ${ }^{178}$

${ }^{175}$ M. Gouriet, "Claims by Cohabitants, Capital and Maintenance Rights with Reference to Legislation in Other Jurisdictions', Solicitors Fanily Law Association Review, June 1999, pp. 25-26.

176. De Facto Relationships Act 1984, section 4:

(1) For the purposes of this Act, a de facto relationship is a relationship between two adult persons:

(a) who live together as a couple, and

(b) who are not related ro one another or related by family.

${ }^{17}$ Property Relationships Act 1984 (New Soutli Wales), section 20(1): On an application by a party to a domestic relationship for an order wader this Part to adjust interests with respect to the property of the parties to the relationship or either of them, a coumt may make such order adjusting the interests of the partics in the property as to it seems just and reasonable hoving regard to:

(a) the finamcial and non-financial contributions made directly or indirectly by or on buhalf of the partses to the relationship io the acquisition, conservation or improvement of ary of the property of the parties or either of then or to the financial resources of the parties or either of them, and

(b) the contribuions, including any contributions made in the capacity of hontersaker or partent, made by either of the parties to the relationship to the welfare of the other party or to the welfare of the fanily constituted by the partics and one or more of the following mamelp:

(i) achild of the parties,

(ii) a child accepted by the parties ar either of them into the household of the parties, whether or not the child is a child of either of the parties.

17. Domestic Relationships Act 1994, (Australian Capital Territory) section 15(1): On application by a party to a domestic relationship, a contr may make an order adjusting the interests in the property of enther or both of the parties that seems just and equatable to it hoving regard ro-

(a) the nature and duration of the relationship;

(b) the financial and non-finamcial cantributions ntade directly or indirectly by or an behalf of either or both of the parties to the acquisition, conservation or improvement of ary of the property or financial resources of either or both of them:

(c) the contributions (including any in the capacity of home-maker or parent, wade by either of the parties to the welfare of the other or any child of the parties; 
Een soortgelyke bepaling is ook opgenomen in artikel 709 van Boek 1 van het ontwerp-BW wan Eritrea. Op grond wan deze bepaling is de rechter bevoegd te bevelen dal goederen van een ex-Samenwoner aan de andere partmer worden vvergedragen. De bepaling is uitsluitend van toepassing op ex-samenwoners die langdurig als man en wrouw hebben samengewoond. De rechter zal, gelet op de omstandigheden van ek geval, noar redelijkheid en billijkheid dienen te beslissen. Hij mag overigens niet bevelen dat meer goederen zullen worden overgedragen dan equivalent is arin de waarde van een derde van de totale goederen van de betrokkene exleefgenoot De rechter zall in het bijzonder rekening moeten houden met het gegeven dat bepaalde goederen verworven zijn door de gezamenlike inspanningen van de lesfgenoten. Tevens moet in de beoordeling worden betrokken of de mogelijkheden van de verzoek(s)er om haar of zijn eigen goederen te verwerven ten gewolge wan de reluthe waren verminderd. 199

Het is begrujpelijk dat men in een land als Engeland, waar men geen wettelijke regeling van het huwelijksgoederenrecht kent, laat staan een regeling voor de goederen van samenwoners, geneigd zal zijn om aansiuiting te zoeken bij de twee Anstralische (deelstatat)regelingen, die de rechter veel ruimte laten bij de afweging van do in anmerking komende belangen. Voor Nederland, dat een uitgebreide regeling van het huwelijksgoederenreclat kent, zou een dergelijke regeling een vreemd eend in de bijt zijn. En zelfs in Engeland gaan er stemmen op voor een meer gestructureerde regeling. ${ }^{180}$ Met het $00 \mathrm{~g}$ hierop is het interessant de desbetreffende Hongaarse en Zweedse wetgeving onder de loep te nemen. Beide landen kennen een speciale wettelijke regeling voor een deel van de vermogensrechtelike relatie tussen ongehuwd samenwonenden.

Art 578/G Hongaarse Burgerlijk Wetboek bepaalt dat met betrekking tot alle goederen die het par staande de relatie heeft verworwen de titel in verhouding zal statu tot de bijdrage aan de verwerving die elke partij heeft gedaan. Wanneer de bijdragen van de partijen niet kumnen worden vastgesteld, worden de bijdragen geacht gelijk te zijn. Bovandien is expliciet bepaald dat huishoudelijk werk wordt aangemerkt als een bijdrage aan de verwerving van de goederen. ${ }^{181}$ Deze bepaling is van

\section{$\rightarrow$}

(d) the matters referred to in subsection 19(2), as far as they are relevant; and

(a) stuch other matters, if any, as the court considers relewant.

Section 19,2): In exercisting a power under subsection (1), a coum shall have regard to

(a) the inconve property and financial rasources of ach pasty.

(b) the physical and mestal capacity of each party for appropriate gainful employment:

(c) the finchelat needs and obligations of each party:

(d) the responsiblities of ether party to support any other person;

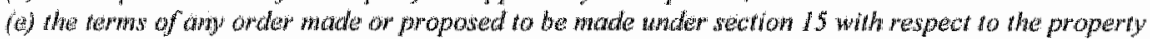
of ewher or botls of the partics, and

(1) awy payments made to the applicant, purstanit to an order of a court or otherwise, in respect of the maintenderse of a child or children.

17 Artikel 709 ontwerp BW van Eritrea:

(1) If ho persons have lived logether for a long twe as if they were married and the relationsthip has broken down, the court may, wpon request, awdord to ond of the former cohabiteess property belanghyg to the other former cohobitee, provided the valwe of such property does not represent whore that one third of the estate of swch other former cohabited.

(2) Thie court shall make such arder as is reasonable in the circumstances.

(3) The court shall take in particular imo account whether the property of swch other former cohab inee was andired by common efforts or whether the possibilities of the former cohative making the request to acquire his or her owm properby were dintinished because of the relationship.

A. Barlow en C. Lind, a.w n. 174, pp. 477-488.

Hongarse Burgerlijik Wetboek, section $578 / 0$ subs. 1. 
loepassing op partners die samenwonen als waten zij gehuwd. Op grond van ean wetswiziging in 1996 worden partners van gelijk geslacht mede in deze definitie geacht te zijn begrepen. ${ }^{182}$

Deze regeling gaat verder dan in Nederland door nadrukkelijk te bepalan dat goederen kunnen worden verworwen door een bijdrage aan de verwerving te doen. De hoofdregel dat de eigenaar degene is aan wie het goed is geleverd wordt hiermee doorbroken. Een dergelijke bepaling zou zich hat meest doen gevoelen mat betrekking tot registergoederen. Met betrekking tot niet-registergoederen kent het Nederlandse recht met art. 3:110 BW al een regeling die in veel situaties tot een gelijke verdeling leidt.

Een verdergaande regeling van de goederenrechtelijk relatie tussen samenwonenden treft men aan in de Zweedse Wet Samenwonenden (Gezamenlijke Woning) (hierna: de Wet Samenwonenden) die op 1 januari 1988 in werking is getreden. ${ }^{183}$ Deze wet heeft het woordeel dat zij reeds gerume tijd in werking is en dat er inmiddels veel ervaring is opgedaan met de praktische uitwerking ervain. De werking wan de wet is onlangs geèvalueerd, hetgeen heef geleid tot een antal aanbevelingen om de doelmatigheid van de wet te verbeteren.

Op grond van de Wet Samenwonenden vallen alle gezamenlijk verworven goederen onder een special regime. Anders dan in de Hongaarse bepaling is de gelijkheid van eigendom het vertrekpunt en wordt in eerste instantie niet gekeken naar de door elk der partijen geleverde bijdrage aan de verwerving van de goederen. De wet is van toepassing wamneer twee personen, van gelijk of verschillend geslacht, 184 samenwonen in omstandigheden die vergelijkbsar zijn met een huwelijk, ${ }^{85}$ De Wet Samenwonenden is niet van toepassing als een van de samenwoners reeds gehuwd is of een partnerschap met een andere heeft geregistreerd. De Wet Samenwonenclen is uitsluitend van toepassing op de gezanienlijke woning en op de huishoudelijke inboedel. Verder geldt de eis dat de goederen zijn verworven met het oog op gezamenlijk gebruk. De regeling is daarom niet van toepassing op, bijvoorbeeld, wakantiehuizen, recreatiegoederen (boot, auto), ${ }^{186}$ bedrijfsgoederen, goederen in de gezamenlijke woning die uitsluitend door een wan de partijen worden gebruikt, of bankrekeningen. ${ }^{187}$ Zolang de relatie voortduurt heeft de regeling geen juridisch effect; elk der partijen blijf eigenaar van haar of zijn goederen en elk der partijen is verplicht de door hem of haar angegane schulden te voldoen. Een enkele bepaling is wel reeds tijdens de relatic van toepassing: evenals bij gehuwden het geval is, is elk van de samenwonenden onbevoegd om zonder toestemming van de partner over de goederen te beschikken die onder het regime van de wet vallen.

Gedetailleerde regels bepalen welke goederen moeten worden verdeeld, ${ }^{189}$ op welke wijze de verdeling van deze goederen moet platsvinden (waronder de vraag wan de verrekening van schulden ${ }^{190}$ ) en in welke gevallen een partij het huis of huis-

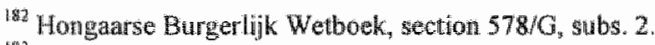

富3 $1987: 232$.

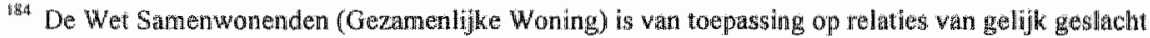
op grond van de Wet Honosexuele Samenwonden, 1987:813.

Hs Wet Samemwonenden (Gezamenhifle Woning), aut. 1.

186 Wet Samenwonenden (Gezamenlijke Woning) art. 4.

${ }^{187}$ Wet Samenwonenden (Gezamenlijke Woning), art. 3 en 4.

sas Samenwonenden (Gezamenligke Woning), ant. 17.

: Wo Samemwonenden (Gezatnenlijke Woning) anti. 7 en 8

tow Wanneer het naw werbonden is ann een te verdelen goed, bijw, hypotheek op liet huis.
} 
houdelike goederen onder verrekening met de andere partij mag ovememen. ${ }^{191} \mathrm{De}$ regels die wan toepassing zijn op de verdeling van de boedel wssen gethwden $z$ in van overeenkomstige toepassing verklaard op samenwonenden. ${ }^{19}$ Indien een der partigen voór de verdeling failliet is verklaard of er andere redenen zijn on niet tot verdeling over te gaan, behoudt elk der partijen zijn/haar eigendom en vindt geen verdeling plats. 193

De Wet Samenwonenden doet zich pas gevoelen als de relatie wordt afgebroken. Een centrale bepaling is artikel 5 waarin is bepaild dat, indien de relatie anders dan door de dood wordi beeindigd, eén van de samenwonenden zich tot de rechter mag wenden met een verzoek tot gellike verdeling wan het gezamenlijk huis en de gezamenlijke huishoudelijke goederen. In het geval van overlijden van een van der partijen kan de overlevende on een gelijke verdeling van de onder de wet vallende goederen verzoeken. Voorts heeft de overlevende partner nog andere rechten, waarower later meer.

Dit is een belangwekkende regeling. Er is een aantal aspecten dat nadere beschouwing verdient.

\section{Gelijke verdeling als vertyekpunt}

Het vertrekpunt van een gelijke verdeling wan de gezamenlijk verworven goederen die in gezamenlijk gebruik zijn, is in vele opzichten zeer aantrekkelijk. Waarschijnlijk is ook dat een dergelijke regeling aansluit bij wat de meeste samenwomende partners in de praktijk doen. Uit het NISSO-onderzoek bleek dat wan de 37 paren die een huis in eigendom hadden, deze in 22 gevallen gemeenschappelijk was. Voor wat de niet-register goederen betreft verkeerde een derde van de paren in de misvatting dat de inboedel gemeenschappelijk was. "19*4, onder andere, het onderzoek van Weitzman blijkt dat de meerderheid van gehuwden, verloofden en samenwonenden paren wilden dat de post-contractueel verworven bezittingen gemeenschappelijk zouden zijn. $^{195}$

Van belang is voorts dat, als er geen bewijs voomanden is voor de eigendom van een niet-registergoed, reeds thans de praktijk bestaat dat met toepassing van artikel $3: 110 \mathrm{BW}$ een gelijke verdeling tussen de partners wordt toegepast. Weliswaar is artikel 3:110 BW slechts een bewijsrechtelijke bepaling en ziet dit artikel dus als zodanig niet op een inhoudelijk afweging van de belangen wan de scheidende partners, maar het is ook weer niet zo dat van deze door de wetgever gekozen oplossing kan worden gezegd dat ze helemal los staat van inhoudelijke argumenten. Zo berust het artikel op de gedachte dat reeds het enkele feit dat een goed gezamenlijk is gebruikt een argument biedt on het goed als gemeenschappelijk an te merken. ${ }^{196}$

Op grond van nog twee andere argumenten zou ik voor een gelijke verdeling als vertrekpunt willen pleiten.

Gelijke verdeling is a antrekkelijk met het oog op de onvoorzienbaarheid van hetgeen zich in de loop van een langdurige telatie zal afspelen. Er kan van alles ge-

|9: Wet Snuenwonenden (Gezamenlijke Woning), art. 10 de partij met de grootste behoefte" (eerste zin) en indien her tredelijk is (tweedre zin)).

Wet Samenwonenden (Gezamenlijke Woning), art 14.

105 Wet Sanvenwonenden (Gezamenlijke Woning) ant. 9 tweede zim.

to: Straver e. a. a. n. 36, pp. 206.

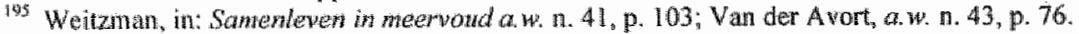

[w Gezonentjk gebrilk werd ook door het Zweedse Hol van Beroep aangenerkt als en argumenit: om crgendom te erkennen, 1974 SWIT rf, p. 71 en 1977 SvJT rf, p. 2 in: Agel, a. w. n. 61, p. 196 en noot 3 . 
beuren waardoor de situatie zoals deze was ten tijde van het sluiten van het contract of het afzien hiervan drastisch verandert: een van de partners kan werkloos worden of juist de loterij winnen of een erfenis ten deel vallen; een van de partners kan ziek worden, falliet gaan, er kunnen kinderen komen. Kortom, de aard van de samenwoningsrelatie brengt mee dat het woor elke partij moeilijk is te voorzien wat de vooren nadelen zullen zijn wan een bepaalde regeling. Vanwege al deze onzekerheden, die de partijen niet in eigen hand hebben, is er veel te zeggen voor een gelijke verdeling van de middelen.

Een tweede argument voor de geiijke verdeling heeft te maken met de inbreng van beide partijen in de relatie. Daarbij speelt de belangrijke vraag of ook een thuiswerkende samenwoner, de huisvrouw of $-\mathrm{man}_{\text {, }}$ recht heeft een op gelijke verdeling van de tijdens de relatie verworven gemeenschappelijke goederen. En hoe zit het als de ene partmer parttime werkt en de andere fulltime en de ene partner ten gevolge daarvan, of om andere redenen, weel minder verdient dan de andere? Gaat het niet een beetje ver om de partner die het meest (of zelfs alles) verdient te verplichten de hellt van de volgens de wet in aanmerking te nemen middelen aan de ander af te staxn?

Bij de beantwoording van deze vragen is het goed in ogenschouw te houden dat de inbreng in de relatie tussen samenwonenden een combinatie is van een economische en een niet-economische inbreng. Als er slechts één inkomen in het gezin is, dan is een gelijke verdeling wan de in aanmerking te nemen middelen cen mechanisme om de niet-economisch werkende samenwoner te laten meedelen in de economische opbrengst van de relatie. Daar komt echter bij dat verschillende auteurs hebben betoogd dat er ook een economisch argument is voor een gelijke verdeling, op grond van het standpunt dat ook huishoudelijke arbeid een economische waarde behoort te hebben. ${ }^{197}$ De economische waarde van de wederzijdse verzorging door samenwoners (nadrukkelijk niet partners) is recentelijk erkend in de op 16 december 1998 aangenomen en drie maanden na deze datum in werking getreden Catalaanse Wet Wedlerzijdze Steun. ${ }^{198}$

In het huwelijk komt de economische waarde wan huishoudelijk arbeid tot uiting in de verdeling van de middelen en in de alimentatieverplichtingen. ${ }^{199}$ Voor partmers die samenwonen als waren zij gehuwd dient mijns inziens voor wat het gezamenlijk opgebouwde vermogen betreft, hetzelfde te gelden. In én-inkomens-

197 Voor argumenten on huishoudelijk werk economisch te belonen, zie: Cohen Henriquez, a. w. H. 59, pp. 13-14 en de verwigingen in noot I (Hooggerechtshof Noorwegen 4 maart 1975, Norsk Reltstidende 1975 , p. 220); meer ternghoudend, derelfde schrijver, $a$ w. n. 5, pp. 94-101, p. 100; Van der Burght, $a$, w. n. 146, pp. 31-35; Weltzmann, in: Samenteven im meenoud, a. w. n. 41, pp. 133-4, en tegen de erkenning van de economische waarde van hushondelijke arbeid: Minkenhof a.w. n. $72, \mathrm{p} .120$; J. van Duifwendijk-Brand, "Naar een nieuw huwelijksvermogensrecht?", versiag wan de studiedag Vereniging WJR en KNB 21 jantuari 1998, Ars Motarians XCM, Deventer, Klu. wer, p. 25 e.w. J. van Duijvendijk. Brand, Afrekemen bij (echijscheiding, Deventer, Kolluwer, 1990.

198 Situaciones convencionales de ayuda mutua y sobre la acogida de personats mayores. De wer voorziet in de mogelijkheid om de rechter te verzoeken om een uitkering toe te kennen ata een persoon die voor de overledene onbetaald heeft gewerkt. De rechter moet rekening houden met de duur van de samemwoning, de toewijding van de verzoeker en haar of zijn economische situatie. Deel 4 wan de wet geeft de rechter de bevoegdheid on een deel van het vermogen van erti overledene aan de verzoeker toe te kennen, indien de verzoeker de overledene had verzorgd. De rechter is bevoegd on de verzoeker tot een kwart van de ertenis toe te kennen indien er erfgenamen zijn en indien er geen erfgenamen zilin, de hele erfenis, art. 45. Deze wet is echter niet wan toepassing op informete huwelijken, maar is bedoeld woor andere vormen van samenwonen.

$1 \%$ Asser-de Boer \& 207, wweede alinea en de verwijzingen daarin. 
relaties zou de gellike verdeling tot compensatie dienen te stekken voor de huishoudelijke bijarage van de met-verdienende partner. In het andere uiterste, waarbil de samenwoners beider buitenshuis werken en evenveel verdienen, is de geljke verdeling een rechtstreche weerspiegeling van de economische inbreng van beide partijen. En in de meest voorkomende ussenvorm; waarin beide partners werken, mar de ten minder verdient dan de andere, vormt de gelijke verdeling van de middelen voor een deel een afspicgeling van de financiele inbreng en moet zij voor het overige gezien worden als een compensatie voor de huishoudelijke bijcrage van de minderverdiknende partner. Voor een dergelijke compensatie zijn weel argumenten aan te voeren. Te denken walt an verschillen in machtspositie die het gewolg kunnen zijn van ongelijke inkomens, aan de huidige discriminatie van de vrouw ten aanzien van de toegang tot de arbeidsmarkt en de inkomenspositie ${ }^{200}$ en aan het voortdurend ondergeschikt maken van het beroep van de vrouw aan haar man en kinderen.

De veronderstelling lijkt gerechtvardigd dat de gemiddelde samenwoner deze argumenten zal onderschrijven. Uit het onderzoek van Van der Avort blijkt dat de meeste samenwoners de emancipatie van de vrouw belangrijk vinden en streven naar een onderling gelijke verdeling van huishoudelijk en buitenshuis werk. ${ }^{201}$

\section{Wenthle regethg wan goederen respectert relatievrijheid}

De Zwedse regeling eerbiedigt de relatievriheid van de partijen. De regeling gript zo lang de relatie duut stechts op één punt in op de vermogenstechtelijke relatie van de partijen. Zoals hierwoor is aangegeven zijn de partners immers niet vij om zonder elkatrs toestemming over de onder het wettelijk regime vallende goederen te beschikken. ${ }^{202}$ Het gaat hier om een zelfde beperking van de beschikkingsbevoegdheid als voor de huwelijkse situatie is voorzien in artikel $1: 88(\mathrm{a}) \mathrm{BW}{ }^{203}$ Voorts hebben de partners de mogelijkheid om zich door middel van een schriftelijke overeenkomst aan de wettelijke regeling te ontrekken. ${ }^{204}$ Aan én bepaling kumnen de partners zich echter nooit ontureken. Deze bepaling ziet op het recht van de ene partij om, indien de andere partij de verhuurder van cle woning is, het hutrecht over te nemen bij de beesndiging van de relatie. Tenslotte is de wettelijke regeling alleen wan toepassing als herop door een van de partijen een beroep wordt gedaan; 205 gebeurt dit niet, dan kan de relatie bij beỉindiging op grond van de normale regels van gescheiden vermogens worden afgewikkeld.

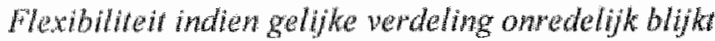

Het utgangspunt van de gelike verdeling heeft tot gevolg dat na de beeindiging van de relatie de ene partij kan worden verplicht goederen aan de andere af te staan. In de casus warower het Hof " $\$$-Gravenhage op 5 januari 1977 uitspraak deed (het Klusjesmanarrest), zon toepassing van dit uitgangspunt ertoe hebben geleid dat de wrouw, die cigenar was van het huis, verplicht zou zijn om de helf wan het huis, of het geldelike equivalent hiervan, aan de man over te dragen. In het bewaste geval had de man een groot deel van zijn inkomen geinwesteerd in de verwerving van het huis en

Whocial en culturet repponl 1998, pp. 222-228.

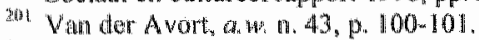

202 Wet Samenwonden (Gezanmenlijke Woning) art. 17.

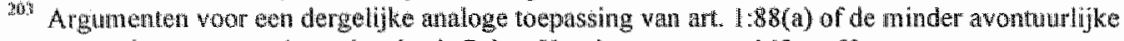
toephssing wan onrechtmange daad: Cohen Menriquez, aw n. 148 , p. 53.

2u Wet Samanwonenden (Gezanenlijke Woning) art: 5 derde zin.

205 Wot Samenwonender (Gezamenlijk Huis) ant. 5 eetste zin. 
vervolgens in de werbouwing daarwan zowel geld als eigen inspaming gestopt. Ben gellike verdeling was in dit geval een redelijk resultaat.

Maar wat als de man niets had gedaan en niets had betaald? In de Zweedse Wet is geregeld dat, indien het in het licht wan de duur wan de relatie, de financiele omstandigheden van de samenwonenden of andere omstandigheden onredelijk zou zijn om een partij te verplichten goederen an de andere te geven, deze ongelijk mogen worden verdeeld. ${ }^{206}$

\section{De goederen die naww werbonden zin ah de samemwoning}

Een wezenlijk punt van overweging voor de het Hof 's-Grawenhage in zijn Klusjesmanarrest was dat het vermogen dat vastlag in de woning van de ex-samenwonenden en waarop de vordering zich richtte, niet los gezien kon worden wan het vermogen als geheel. Zo al tot de werdeling van de woning zou worden besloten, viel niet in te zien waarom deze verdeling niet voor het gehele vermogen zou hebben te gelden. Deze redenering heeft het bezwaar dat zij in feite neerkomt op een thaloge toepassing van het voor gehuwden geldende beginsel van de gemeenschap van goederen. Zou in Nederland een soortgelijke regeling als de Zweedse worden ingevoerd, dan zouden de samenwonenden in dit opzicht niet met gehuwden worden gelijkgesteld. Volgens de Zweedse regelling vallen alleen de goederen die tijdens de relatie zijin verworven in de gemeenschap. Bovendien zjet de regeling slechts op goederen die bedoeld zilim voor gezamenlijk gebruik. Het gaat dus uitsluitend om het huis warin de partners gezamenlijk hebben gewoond en om de goederen die zij gezamenlijk hebben verworven voor gezamenlijk huishoudelijk gebruik. De Zweedse wet heeft geen betrekking op goederen die geërfd zijn of die als geschenk zijn gekfegen. Deze goederen maken dus geen deel uit van de gemeenschap van samenwonenden. Jeze beperkin. gen sluiten mijns inziens goed aan bij de aard en strekking wan de relatie, althans de aard en strekking waarwan de rechter mag uitgaan bij gebreke van bewijs van het tegendeel. Een dergelijke vermogensrechtelijke regeling die aanshit bij de aard en strekking van de samenwoningsrelatie heeft in het Nederlandse recht al enige erkenning gevonden, zoals blijkt uit eerder besproken uitspraken door de rechtbank Groningen inzake de Leekse samenwoners en het Hof 's-Gravenhage in het Huurwoning arrest en waarin met betrekking tot de goederen die de partners tijdens de relatic hadden verworven een beperkte gemeenschap van goederen werd aangenomen. ${ }^{20 \%}$ Dat twee mensen samen gaan wonen brengt mee dat zij een huis betrekken en hierin een gezamelike hushouding voeren. Het huis en de hushoudelijke goederen zijn nauw werbonden met de relatie. Er zal veelal sprake zijn van een geramenlijke financiele en niet-financiele bijdrage. En de bedoeling bij de aanschaf van de goederen zal zijn dat beide partijen hiervan gebruik kunnen maken. Zeer relevant voor de toepassing van de wet is de bedoeling die partijen bij de aanschat hadden. Deze bedouting zall dikwijls kunnen worden afgeleid uit de aarc van het goed. Een computer die tij dens de relatie is aangeschaft, mar die niet is bedoeld voor gezamenlijk gebruik, valt niet onder de regeling. ${ }^{20 \%}$ De uitsluiting van goederen die verworven zijn vón het begin van de relatie spreekt voor zichzelf. Deze goederen kunnen niet zijn verworven door financièle of niet-financièle inbreng wan beide partijen gezamenlijk, woch kunnen zij aangeschaft zijn met het oog op gezamenlijk gebruk. Voorts is do beperking wan de goederen die in de gemeenschap vallen in overeenstemming thet het gegeven

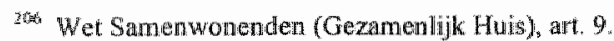

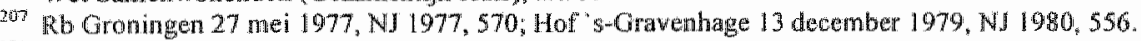

zö: Wet Satmenwonenden (Gezamenlik Huis) art. 3 lwede zin. 
dat de samenlevingsrelatie tijdelijk kan zijn. Onder nomale omstandigheden heeft men meer vermogen te verdelen bij beeindiging van een langdurige dan wan een kortstondige relatie.

De elegantie van de aansluiting bij de goederen die nauw verbonden zijn aan de samenleving kan worden geillustreerd door middel van een vergelijking met het eerder besproken Boek I van het Ontwerp BW van Eritrea. Volgens artikel 709 is de rechter bewoegd om een ex-samenwoner te bevelen on goederen aan de andere over te dragen: de rechter mag een samenwoner echter niet bevelen om meer goederen over te dragen dan equivalent is aan de waarde van een derde van zijn of haar totale goederen. Door dit artikel is de alanspraak die op de goederen van een exsamenwoner kan worden gemaakt beperkt. Deze beperking sluit echter niet aan bij de betekenis die de goederen hebben in ce context van de gewezen relatie. Bovendien is de beperking tot een derde van de goederen gebaseerd op een analogie met het huwelijk. Zoals hiervoor al is aangegeven, gaat een gelijkstelling met het huwelijk veelal voorbij aan thet eigen karakter van de relatie tussen samenwoners.

De hier besproken $Z$ weedse regeling vertoont op een aantal punten gelijkenis met de in de artikelen 1: 123-128 BW geregelde gemeenschappen van vruchten en inkomsten, met dien verstancle dat de $Z$ weedse regeling geen regeling van de schulden van de samenwoners bevat. Zo is op grond van artikel 1:124 lid 1 BW de gemeenschap van vruchten en inkomsten, evenals de Zweedse regeling, beperkt tot de goederen die de echtgenoten tijdens het bestaan van de gemeenschap anders dan door erfopvolging, making of gift hebben verkregen. Evenals de Zweedse regeling heeft de gemeenschap van vruchten en inkomsten geen betrekking op beroeps- en bedrijfsvermogen. (artikel 1:126 BW). Maar anders dan de gemeenschap van vruchten en inkomsten ziet de Zweedse regeling op een gemeenschap die ook beperkt is naar de aard van de goederen: slechts het gemeenschappelijk huis en de inboedel behoren hicrtoe.

\section{Mrustratie van de tepassing van de Wet Samenwonenden}

We blikken nog eens terug op de eerder behandelde Nederlandse jurisprudentie, om te zien in welke gevallen de Zweedse wet verschil zou hebben uitgemakt. In de casus van rechtbank Assen van 8 maart 1983 en 7 februari 1984 (Cafetariaondernemingarrest)" 2010 en Hof 's-Gravenhage van 5 januari 1977 (Klusjesmanarrest ${ }^{210}$ zou de man de helft van de waardestijging van het huis hebben gekregen. De Zweedse wet zon echter niet van toepassing zijn op het bedrijfspand en de bedrijfsgoederen in het Cafetaria-ondernemingarrest. De Zweedse Wet zou niet geholpen hebben in de Bouvier-zatak ${ }^{211}$ en evenmin in de Caravan-zaak ${ }^{212}$, omdat noch de hond noch de caravan onder de inboedel in de zin vam de $Z$ weedse wet zouden vallen. In de zaak Smit-Bruinsma ${ }^{213}$ zou de Zweedse wet niet van toepassing zijn geweest op de bankrekeningen, maar zou Bruinsma recht hebben gehad op de helft van de gezamenlijke goederen. Omdat de relatie was beěindigd door de dood van haar partner, zou zij bovendien recht hebben gehad op een wettelijk bepaald bedrag. In de Ker-

\footnotetext{
Wal 1987,427

*10 N1977,569.

3t HR 8 oktober 1982, N1 1984, 2 m. nt Burnuer.

212 $\mathrm{Rb}$ Amsterdan 21 juli $1983, \mathrm{KG} 1983,248$.

31) HR 16 januari 1987 , NJ 1987,912 m. nt. Luigten.
} 
misboedelzaak ${ }^{214}$ zou de vrouw recht hebben gehad op de helf van de warde van het huis. De kermisartikelen zouden daarentegen niet in de gemeenschap vallen.

\section{Derdenbescherming}

Het restrictieve standpunt dat in Nederland met betrekking tot registergoederen wordt ingenomen, wordt wooral ingegeven door motieven van derdenbescherming 21 s Het is dan ook interessant te bezien hoe de Zweedse Wet Samenwonenden de positie wan derden regelt.

Op grond van artikel 19 van de Wet Samenwonenden kan een exsamenwoner zich tot de rechter wenden, indien zijn/hatr voormalige partner over een goed beschikt warover hij of zij op grond van de wet geen recht kon doen gelden. De rechter kan de beschikking over het goed onrechtmatig verklaren en kan bepalen dat titel of bezit wordt hersteld. De derde die het goed inmiddels te goeder trouw heeft verkregen wordt echter beschermd. ${ }^{216}$ In Nederland zou het wenselijk zijn om de versoepelde "goede trouw" van artikel 1:92 BW in deze situatie toe te passen.

- Onder het regime van de Wet Samenwonenden moet de partij die de onrechtmatigheid wan het bezit wan een goed wil inroepen er bovendien geen gras over laten groeien. De vordering dient binnen drie maanden nadat de ex-partner op de hoogte is geraakt van het onrechtmatige bezit te worden ingediend. In het geval wan registergoederen kan de actie niet worden ingesteld indien registratie van een overdracht van de eigendom of wan de vestiging of overdracht van het recht van erfjpacht heeft plaatsgehad. 217

\section{Mogelijke herziening van de Zweedse regeling}

In 1998 is in Zweden een commissie ingesteld om de werking van de Wet Samenwonenden (Gezamenlijke Woning) te evalueren. De commissie kreeg onder meer de opdracht ${ }^{218}$ om na te gaan of het met de wet beoogde doel, te weten het garanderen van een minimaal niveau aan bescherming voor de zwakkere partij bij de beeindiging van de samenwoning, optimaal was bereikt. De commissie heeft haar rapport in oktober 1999 uitgebracht. ${ }^{219} \mathrm{Zij}$ heeft de volgende vooustellen gedaan:

a. De wet moet worden vernoemd tot Wet Samenwonenden. Weliswaar achtte de commissie de huidige titel waarin wordt verwezen naar de gezamenlijke woning meer informatief; de commissie merkte echter op dat de kennis van de gemiddelde burger over de wet zo mager is dat dit geen reden kan zijn on de oude titel te behou. den: 220

b) De wet moet rechtstreeks ook van toepassing zijn op paren van gelijk geslacht, en niet slechts door middel van een verwijzing in de Wet Homoseksuele Samenwonenden, zoals nu het geval is. De huidige situatie leidt tot onzekerheden over de betekenis van het begrip "samenwonenden als waren zij gehuwd";

214. HR 26 mei 1989, NJ $1990,23 \mathrm{~m}$. nt Lü̈ten.

21s Hof s-Cravethage, 5 janwari 1977. NJ 1977, 569; Modehuis Nolly, HR 2 aphl 1976, NJ 1976, $450 \mathrm{~m}$. nt. Meyn.

216 Art. 19 derde zin.

31 : Art. 19 tweede allinea, tweede zin.

218 De opdracht was drie rele nagan of de bescherming optimat was; nagatu of de huidige verschillen in behandeling van samenwonenden van gelijk geslacht en verschillende geslacht nog te rechtvaardigen zijn; nagasn of andere soonten van huishouding onder de bescherming van de Wet Sarmenw onvenden moeten worden gebracht.

$21050 U 1999: 104$

200 English summary, p. 28 
c) Er moet ex niferwe wettelijke omschrijving komen van de groep samenwonenden die onder het regme van de wei valt. In de plaats van een werwizing naar het huwelijk zou moeten worden bepald dat het begrip samenwonen in de zin van de Wet Samenwonenden ziet op twee personen die duurzam als een paar samenwonen en die een gezamenilike huishouding voersm. 221

d) In de huidige Wet Samenwonenden wordt een aantal gevolgen gekoppeld aan de dawm warop de relatie eindigt. Maar nergens in de Wet Samenwonenden is bepaald wanneer de relatie geacht moet worden te zijn beaindigd. Volgens de commissie zou in de wet moeten worden vastgellegd dat er sprake is wan beëindiging wanneer dit ncar derden toe blijkt. De relatie zou in ieder geval geacht moeten worden beêndigd te zijn, als een van de partijen met een ander trouwt, een partnerschap registreert, het huis verlaat of sterf. Voorts acht de commissie de relatie beëindigd, als éen partij, of beide partijen, cen verzock tot verdeling van het vermogen heeft ingediend of zich in rechte heeft beroepen op het recht om in het huis te blijven wonen. ${ }^{22}$

e) Naar het oordeel van de commissie zou ook de auto onder het regime van de Wet Samenwonenden moeten vallen, omdat het gebruik van de auto in veel gezinnen zeer nauw verband houdt met huishoudelijke activiteiten, zoals winkelen en het vervoer van de kinderen. ${ }^{223}$ Daarentegen zou een auto die voornamelijk voor recreatie wordt gebruikt, niet onder de regeling mow ten vallen. ${ }^{224}$

1) Samenwonenden kunnen gezamenlijke vermogens hebben die niet onder het regime van de Wet Samenwonenden wallen (bijwoorbeeld een vakantichuis dat op beider naam stal). Voor de verdeling van deze gemeenschappelijke eigendom geldt thans een ander wettellike regime dan van toepassing is op de goederen die onder de Wet Samenwonenden vallen. Dit leidt tot veel rompslomp en tot de wens om de verdeling van alle gezamenlike eigendom om uniforme wijze te regelen. De commissie was van oordeel dat dit probleem haar opdracht te buiten ging, maar heeft wel aandacht voor dit probleem gevraagd. 225

g) In de praktijk bestat onzekerheid over de vraag of het mogelijk is om bepaalde goederen van de werking van de Wet Samenwonenden uit te sluiten (bijwoorbeeld huishoudelijke goederen) terwijl andere gemeenschappelijke goederen (bijvoorbeeld het huis) wel onder de regeling blijven vallen. De commissie beveelt aan in de wet ondubbelzinnig tot uitdrukking te brengen dat een gedeeltelijke uitsluiting wan de Wet Samenwonenden mogelijk is. ${ }^{226}$ Samenwoners zouden woorts, net als gehuwden, de mogelijkheid moeten hebben om een beëindigingsovereenkomst te sluiten 27

b) Samenwoneners zijn miet verplicht om hun goederen te verdelen na de beèndiging van de relatie. Ter bevordering van de rechtszekerheid beweelt de commissie aan dat de verdeling binnen een jaar na de beêndiging van de relatie moet plaatsvinden. ${ }^{228}$

i) Indien een van de partijen onder de Wet Samenwonenden vallende goederen na de beěindiging van de relatie maar vớr de verdeling verkoopt; weggeeft of anderszins verwijdert, wordt de waarde wan de verwijderde goederen volgens de thans geldende

23: Hoid, p. 28

ribid. pp. 28,29

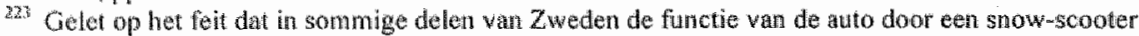
of een motor boot word vervald, zouden ook deze voertigen volgens de commissie onder de bescherming wath de wet moeten vallen.

Hrat Hid. p. 29 .

Nos Uid,, 30 .

20 wid. p. 30 .

2h Hid. pp. 30 m 1

20 Hid. p. 31 . 
regeling niet in de verdeling betrokken. De commissie stelt woor dergelijke goederen wel in de verdeling te betrekken door de waarde van de thele boedel te berekenen zoals deze was op het moment van de beëindiging.

j) De commissie constateert dat er matregelen moeten worden genomen om meer informatie over de wet te verstrekken, met name aan jongeren, allochtonen en paren van gelijk geslacht. ${ }^{229}$

\section{Samenloop van vermogensrechtelijke verplichtingen}

De Zweedse Wet Samenwonenden is niet van toepassing indien een wan de samenwoners, of beiden, tijdens de relatie met iemand anders is getrouwd. Deze regel woorkomt de samenloop van vermogensrechtelijke relatieverplichtingen. Deze regel mag de wet gemakkelijker hanteerbaar maken voor juristen, maar kan in de praktijk tot zeer vervelende resultaten leiden. Zo zou in een van de meest aangrijpende Nederlandse zaken over samenwoners - de zaak waarover de HR op 13 november 1987 besliste, ${ }^{230}$ de vrouw, die met een gehuwde mar samenwoonde, geen enkele aanspraak kunnen maken op de gezamenlijk met deze man aangeschatte goederen voor gezamenlijk gebruik (behoudens de bewijsrechtelijke bescherming die de artikelen 3:1.10 BW en 1:131 BW bieden met betrekking tot niet-registergoederen). Het ging in deze zaak om een hurwoning. Als de partners het huis, ten behoeve van gezamenlijk gebruik, op naam wan de man zouden hebben gekocht, zou de wrouw op grond van het huidige Nederlandse recht haar aanspraak geldend kunnen maken als een stilzwijgende overeenkomst tot verrekening van de waarde van het huis kan worden bewezen. Op grond van de Zweedse regeling zou de vrouw echter geen enkele aanspraak kunnen maken om de enkele reden dat de man is gehuwd.

Deze bepaling uit de Wet Samenwonenden verdient mijns inziens geen navolging. Zij ontneent bescherming aan iemand die deze behoeft. Bovendien kent de huidige Nederlandse wetgeving al een samenloop op het gebied van de alimentatieverplichtingen. Bij vaststelling van de alimentatie die een man aan zijn ex-vrouw moet betalen kan de rechter immers rekening houden met het feit dat de man met een nieuwe partner samenwoont en zelfs met het feit dat de nieuwe partner kinderen heeft. ${ }^{231}$ Een en ander kan sneu zijn voor de echtgenote die ontdekt dat haar man een gezamenlijk vermogen met iemand anders heeft opgebouwd. Daar staat echter tegenover dat de vordering van de samenwonende (nieuwe) partner beperkt blijft tot de goederen die nauw aan de samenwoning zijn verbonden, terwijl de vordering van de voormalige echtgenote, indien zij in gemeenschap van goederen was gehuwd, het geheel van het resterende vermogen van de man zal betreffen. Voorts acht ik het, gelet op het feit dat de gewrakte Zweedse bepaling alleen ziet op de situatie dat de partners in de (nieuwe) relatie samenwonen als waren zij gehuwd, nauwelijks denkbaar dat de voormalige echtgenote wan de man niet op de hoogte was van de situatie. Er mag dus van haar worden verwacht dat zij eerder maatregelen zou nemen om haar rechten te beschermen. Kortom, ik zie het samenwonen van partners van wie er een is gehuwd als een complicatie voor de toepassing van het in de Zweedse wet gelegen wettelijke regime, maar niet als een reden om de toepassing van deze wet op deze situatie uit te sluiten.

229 Mbid, p. 32.

230 NI $1988,254 \mathrm{~m}$. nt. Stein

21 HR I9 november 1971, NI 1972, 337, m. ne Luijten; HR 22 juli 1981, N1 1982, 283 m. nt. Luijten; HIR 27 november 1981, NJ1982, 284 m. nt. Luịten; HR 3 juh 1995, NJ 1996, 86, nn.nt. de Boer. 
Met betrekking tot de regeling wat hebrik van de gezamenljke woning na de beeindiging van de relatie, is het nodig om een onderscheid te maken tussen een woning die in eigendom is van een of beide partien en een hurwoning. In deze paragraif gaat het om een eigendomswoning.

Met betrekking tot de verdeling van goederen bepaalt de Wet Samenwonenden dat de samenwoner die de sterkste behoefte heeft aan de woning of de huishoucelijke inboedel deze goederen bij de boedelscheiding toebedeeld zal krijgen, met compensatic van de warde ervan aan de wederpartij. Als de woning waarin de samenwoners gezamenlijk hebben gewoond eigendom is van een van hen, mag de wederpartif de woning slechts owernemen indien dit in het licht van alle omstandigheden redelijk is. ${ }^{232}$

De Nederlandse rechter heeft thans reeds de bevoegdheid te bepalen welke partner de woning mag gebruiken, zelfs indien de woning reeds voordat de samenwoning een aanvang nam was gekocht. ${ }^{233}$ De rechter zal deze bevoegdheid uitoefenen overeenkomstig de beginselen van de goede trouw. ${ }^{234} \mathrm{Bij}$ de belangenafweging kan rekening worden gehouden met, bijwoorbeeld, de funanciële belangen van de eigenaar bij een spoedige verkoop wan de woning of de behoefte van de eigenaar om de woning te gebruiken als eigen woontuimte, ${ }^{25}$ de tijd die de niet-eigenaar noding zall hebben om nieuwe woonruimte te winden, ${ }^{236}$ de verwachting van de niet-eigenaar dat het (mede)gebruik van de woning van duurzame aard zal zijn, het feit dat ten tijde van het ontstaan van het (mede)gebruik de niet-eigenaar de woning die deze voór de relatie had op korte termijn zou verliezen, dan wel om met de eigenaar te gatu samenwonen een duuraam in gebruik zijnde eigen woonruimte heeft moeten prijsgeven. $^{237}$ Van geen enkel belang is of de samenwoners trouwplannen hebben gehad. ${ }^{238}$ Zou worden besloten tot invoering van een soortgelijke regeling als is voorzien in de Zweedse Wet Samenwonenden, dan zou ter beantwoording van de vraag welke partij het gebruik van het huis zal krijgen kunnen worden uitgegaan van de hier beschreven belangenafweging.

De Zweedse rechter beeft voorts de bevoegdheid om te bepalen wie van de samenwoners de woning en de gezamenlijke goederen mag gebruiken hangende de hoofdprocedure. 239 De Nederlandse rechter heeft deze bevoegdheid bij wege van ordemaatregel. $^{240}$

\section{Hourrecht}

Indien het huurrecht niet in de verdeling van goederen is betrokken (zie vorige alinea), heeft de Zweedse rechter op grond wan de Wet Samenwonenden de bevoegdheid het humrecht van de gezamenlijke woning aan cen van de samenwoners toe te

292: Wet Samenwonenden (Gezamentijke Woning), art. 10, tweeds en derde zinnen.

23: A.r. Mb Zwolle 23 oktober 1979, NJ 1981, 328 .

3.14 Ar. Rb 2wolle 8 april 1982, RvdW/KO 1982,72 o., 5.

23. Arr, $\mathbb{R b} 2$ wolle, 23 oktober 1979, W $1981,328$.

23. RB. Gromingen 9 junuari 1979, W. 1979, $35 \mathrm{l}$

397 Arr. Rb Zwolle 23 oktober 1979, N1 1981,328

236. Arr. Rb Zwolle 8 april 1982, Rvd W/KO 1982,72 0, 7 en 8.

339 Wer Smanwonenden (Gezamentijke Woning), artt. $21-24$.

240 Hof "s-Grvenhage 13 december 1979, No 1980, 556 o.w. 5 (p. $1821 \mathrm{k}$ ). 
Kennen na beeindiging van de relatie. ${ }^{241}$ De rechter moet, bij de uitoefening van doze bevoegdheid, het hurrecht toekennen aan de samenwoner die het de grootste behoefte heeft aan de woning, indien het, in het licht valu alle omstandigheden, redeligk is. Indien de samenwoners geen gezamentijke kinderen hebben en hebben ze nooit gehad zal de rechter slechts in buitengewone onstandigheden het huurrecht an de niet-huurder toekennen. Denkbaar is bijvoorbeeld dat het humrecht aan de niethumder zou kunnen worden toegekend indien de woning angepast was aan de lichamelike handicap van een van de samenwoners. De samenwoner die het huurrecht op grond van deze bepaling krijgt zal met de andere siamenwoner de waarde van het huurrecht moeten verrekenen. ${ }^{242}$ Opmerkelijk is dat deze bepaling de toekenning van het huurrecht mogelikk maakt niet alleen ten behoeve van een samenwoner die de woning nodig heeft ondat hij of $\mathrm{zij}$ de zorg voor minderjarige kinderen heeft, maar ook ten behoeve van een samenwoner die kinderen heeft gehad. Impliciet is de er kenning van de financiele verstnengeling die gemakkelik gepaand gaat met de opvoeding van kinderen en die voor de economisch zwakkere partij haat werking laat woelen lang nadat de kinderen het huis hebben verlaten.

In Nederland, indien een samenwoner de huurder van een woning is, heeft de andere samenwoner de mogelijkheid op grond van art. $7 \mathrm{~A}: 1623 \mathrm{~h} \mathrm{BW}$ mede-huurder te worden. ${ }^{243}$ Het moet gaan on het huurrecht met betrekking tot het hoofdverbliff van de samenwoners: net als in Zweden is er geen bescherming voor recreatiewoningen, en zij moeten gedurende minstens wee jaar in het hoofdverbliff een duurzame gemeenschappelijke huishouding gevoerd hebben. ${ }^{24}$ Deze bepaling was bedoeld om de samenwoner bescherming tegen de verhuurder te bieden; de samenwoner-huurder en zijn partner moeten gezamenlijk de verhuurder verzoeken de samenwoner alls mede-huurder te aanvaanden en bij weigering van de verhuurder, noet hun verzoek gezamenlijk aan de kantonrechter worden gericht. Dit was juist een probleem in een zaak waarover de Hoge Raad op 13 november 1987 moest oordelen: want de samenwoner-hurder weigerde om aan een verzoek mee te werken. Dit was niet zo verrassend omdat de samenwoner-niet-huurder vorderde op grond van art. 7A:1623h lid $7 \mathrm{BW}$ de kantonrechter te bepalen dat de huuder de huturovereenkomst niet meer zou mogen voortzetten. De achtergrond was dat de huorder de woning had gehuurd voor eer vrouw, twee-en-dertig jaar zijn junior, met wie hij een relatie had. $Z_{i j}$ woonde daar sinds 1971 en baarde voor hem twee kinderen. "Toen zij uit elkaar gingen weigerde de man mee te werken aan het verkrijgen van de positie van mede-huurster door de vrouw. De kantonrechter wees haar verzoek af. Door het ontbreken van de medewerking van de samenwoner-huurder kon werzoekster niet op rechtmatige wijze mede-huurster worden, waardoor de bevoegdheid op grond van lid 7 om te bepalen dat de huurder niet meer de hurovereenkomst zou voorzetten, niet tot de mogelijkheden behoonde. Volgens de Hoge Raad, indien de verhuurder zich bereid had verklaard de verzoekster als mede-huurster te aanvaarden "behoeft de ontvankeljikheid in een verzoek als dat van $X$ to toepassing van art. 162 3h lid 7 niet onder alle omstandigheden af te stuiten op het feit dat miet een gezamenlijk verzoek tot verkrijging van de positie van medehuurder is overlegd. Niet uitgesloten is im

2* Wel Samenonenden (Gazamenlije Woning), wh. 16, eerste adinea De clam moet binnen drie manden na vertuck van de woning worden ingediend, art. 16, allinea 2 .

242 Wet Sinenwonenden (Gezamenlijke Woning), art. 16. derde alinea.

243 Ingevoerd door de Wet van 21 juni 1979, stb. 1979, 330 houdende bepalingen met betreking tot hum en verhthur van woonmimte, invoeringswet $5 \mathrm{~b} .1979,331$.

244 Art. 7A:1623h lid 3 (a). 
mers dat de eisen wan de geede frouw in de gegeven omstandigheden eraan in de weg stan dat de huwder wiens husgenote zonder zin medewerking en erkenning als medehuirster van de verhuurder heef verkregen, zich jegens de husgenote op het ontbreken van de medewerking kan beroepen. ${ }^{245}$ Door dit arrest samen te lezen met art. $7 \mathrm{~A}: 1623 \mathrm{~h} \mathrm{kan} \mathrm{in} \mathrm{Nederland} \mathrm{wan} \mathrm{een} \mathrm{soortgeluke} \mathrm{bescherming} \mathrm{worden} \mathrm{gesproken}$ als in art. 16 wan de Zweedse Wet Samenwonenden is geregeld.

Indien beude samenwoners partij zijn bij de huwrovereenkomst dient de beslissing over het voorlopig gebruik van een huswoming te worden genomen natr redelikheid en billykheid afwegend de belamgen van beide partijen en hun kindeten. ${ }^{246}$ Van het arrest van de $\mathrm{HR}$ van 13 november $1987^{247}$ lijkt het mij redelijk af te leiden dat dit ook geldi indien de samenwoners niet allebei partij zijn bij de huurovereenkomst maar dat het in strijd zou zijn met de goede trow om geen rekening te houdlen met de belangen wan de niet-humder.

Hoewel de Nederlandse regeling na de creatieve oplossing van de HR op 13 novenber 1987 een adequate regeling biedt is anige aanpassing van art. $7 \mathrm{~A}: 1623 \mathrm{~h}$ $\mathrm{BW}$ wenselijk. Dat iemand slechis mede-huurder kan worden met medewerking van de huurder ligt art. $7 \mathrm{~A}: 1623 \mathrm{~h} \mathrm{BW}$ ten grondslag. ${ }^{248}$ Met name zit het arrest van de HR niet goed met de bepaling in lid 7, tweede zin: "Teder wan de personen bedoeld in het vierde lid kan vorderen dat de kantonrechter zal bepallen dat een of meer van deze personen de hurrovereenkomst met ingang van een in het wonnis te bepalen tijdstip niet langer zullen voortzetten. De kantonrechter wijst de vordering slechts toe, indien dit naar billijkheid, met inachtneming van de omstandigheden van het geval, geboden is, met dien verstand dat hij de vordering in ieder geval toewijst, indien de eiser aantoont dat de persoon warop de vordering betrekking heef, zijn positie van medehuurder heef gekregen op grond van een niet mede door de eiser aan de hum der gedaan verzoek of van een door hem ingestelde vordering als bedoeld in het eerste lid." De tweede zin van dit lid behoeft aanpassing, om duidelijk te maken dat een persoon die op grond wan de toepassing van de goede troww ontwankelijk is een verzoek tot toepassing van lid 7 eerste zin niet op grond van de tweede zirn van hetzelfde lid moet worden: uitgezet.

\section{De positie na de dood van een van de samenwoners}

Zorgen over de positie van de overlevende partner vormen de belangrijkste reden waarom samenwonenden naar de notaris gaan om een samenlevingsovereenkomst op te laten stellen. Dit is terecht, want bij gebreke van een testament of verblijwensbeding wan de overleden partner kent het Nederlandse recht slechts beperkte mogelijkheden om an de overblijvende partner legemoet te komen.

De samenwoner die de status wan medehuurder heeft gekregen mag de huurovercenkomst na de dood wan de partner als hurder voortzetten. ${ }^{24}$ ook de samenwoner die niet de status van medehuurder heeft, mar die in de woning zijn hooflverblift heeft en met de overleden hurder een durzame geneenschappelijke

3 november 1987 N1 1988,254 m. nt. Stein. 0.w 3.3

246 Arr. Rb. "s-Hertogenbosch 25 mei 1981, NJ 1981,674 .

${ }^{247}$ NJ 1988, 254.

${ }^{248}$ EK 1978-1979,14249, nr. $113 a$, p. 8

39 Ant 7 A:1623i BW 
huishouding heeft gehad, ${ }^{250}$ heeft het recht de huurovereenkonst gedurende zes maanden na het overlijden wan de huurder voort te zetten. De kantonrechter kan deze periode verlengen, mits een daartoe strekkend verzoek wordt ingediend voordat de termijn van zes maanden is verlopen.

Ook in het nieuwe erfrecht geldt voor de samenwoner een 'zes-maknden regeling". In art. 4.2A.2.1 lid $2 \mathrm{BW}$ is bepaald dat een persoon die tot het overlijden met de erflater een duurzame gemeenschappelijke huishouding voerde, het recht heeft gedurende een termijn van zes maanden in de woning te blijven waar de erflater zijn laatste verblijf had en om de inboedel ervan te gebruiken.

De vraag is of dit, mede in het licht van het voorgaande, voldoende kan worden geacht. Een belangrijke functie van het erfrecht is dat het als voortzetting van een onderhoudsverplichting kan werken. ${ }^{251} \mathrm{Ik}$ heb hiervoor betoogd dat, ook wanneer de partners geen overeenkomst hebben gesloten, de alimentatiebehoeftige samenwoner na de verbreking van de rellatie de mogelijkheid zou moeten hebben on zich tot de rechter te wenden met het verzoek een door de andere samenwoner te betaien levensonderhouduitkering wast te stellen. Deze mogelijkheid zou niet in alle gevallen van samenwoning moeten gelden, maar slechts indien hieraan een invulling is gegeven op een wijze die tot gevolg heeft dat de ene partner financieel afhankelijk van de andere is geworden. De verplichting om dit soort behoeftigheid te bestrijden behoort ook na de dood te bestaan. In het Nederlandse recht ontstaat deze verplichting alleen als deze bij testamentaire voorziening ten behoeve van een achterblijvende parther is vastgesteld. Er bestaat echter nog altijd enige praktische belemmering voor het maken van testamentaire voorzieningen gezien de regeling in het successierecht. ${ }^{252}$ Als het voorstel van de Commissie Moltmaker tot wet wordt verheven, valt dit bezwaar tegen het maken van testamentaire beschikkingen weliswaar weg. De andere bezwaren tegen de in het Nederlandse recht kennelijk levende verwachting dat samenwoners een en ander wel zelf zuilen regelen, zijn echter nog volop aanwezig. Even zo goed als het niet realistisch is te verwachten dat een samenwonende partner steeds geneigd zal zijn een gedurende de relatie te effectueren alimentatieverplicht te laten vaststellen, is het risico groot dat een samenwonende partner evenmin zal denken aan het maken van een testamentaire voorziening ten beloeve van zijn of haar achterblijvende verzorgingsbehoeftige partner. Om deze reden is het begrijpelijk dat Luijten ooit heeft voorgesteld de achterblijvende partner clie geheel of ten dele door de overledene werd verzorgd, een aanspraak te geven op een som ineens ten laste van de nalatenschap van de overledene door het opnemen van een hiertoe strekkende regeling in Boek 4, Titel 2A, atdeling 2 ("andere wettelijke rech(ten'). ${ }^{253}$

Een andere situatie waarin een speciale erffechtelijke voorziening ten behoeve wan de langstlevende partner wenselijk kan zijn doet zich voor wanneer de inkomens van de partners verstrengeld zijn, zonder dat er sprake is wan een economisch afhankelijkheid van de ene partner jegens de andere, ten gevolge waarvan cle overlevende partner gedurende een korte periode financieel in de knel kan komen wanneer

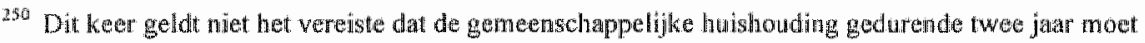
zijin gevoerd.

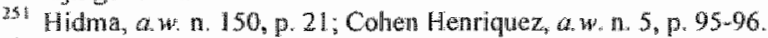

252 Successiewet van 28 juni $1956, \mathrm{Stb}, 1956,362$, art. 32 lid 14 onderded e juncto art. 24 lid 2 letter ta.

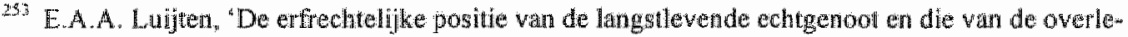

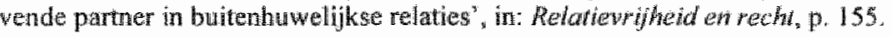


het inkomen en de goederen die deel witmaakten wan het economisch geheel plotseling wegallen. Het is deze situatic waratan artikel 4.2A.2. B BW beoogt tegemoet te komen. In de Zweedse Wet Samenwonenden is eveneens een voorziening voor deze situatie opgenomen, maar deze biedt geen oplossing voor de verzorgingsbehoeftige overleden partner, die in feite langdurige alimentatie nodig heeft.

Het 2 weedse recht kent de overlevende partner geen plaats toe in het versterferfrecht. Dit is een van de belangrijkste verschillen net gehuwde partners. De Wat samenwonenden kent de overlevende partner echter wel bepaalde beperkte rechten toe. In de eerste plats is het aan deze wet ten grondslag liggende beginsel de gelijke verdeling van de gezamenlijk verworven en gebnikte goederen - niet slechts van toepassing bij het uit elkaar gaan van de partners, maar ook als een van de partners komt te overlijden. De achterblijvende partner kan tot het tijdstip van gereedkomen van de inventaris van de nalatenschap aanspraak maken op de hem of haar krachtens de Wet Samenlevenden toekomende rechten. ${ }^{254}$ Met betrekking tot de goederen die onder het regime van de Wet Samenwonenden vallen heeft de overlevende partmer recht op de helft, terwijl de arfgenamen recht op de andere helft hebben. Aan de overlevende partner kont echter een voorkeurspositie toe: slechts de overlevende partner heeft het recht om de gezamenlijk woning en inboedel, witeraard na werrekening van de waarde hiervan, over te nemen. Deze regeling plaatst de overlevende partner in Zweden in een aanzienlijke betere positie dan in Nederland. De regeling heoft niets met het erfrecht te maken, maar is vergelijkbaar met een scheiding van de boedel van gehuxden na het overlijden van een van de echtgenoten.

In de tweede plats heeft de overlevende samenwoner bij de verdeling van de gemeenschappelijke goederen recht op een deel van het vermogen dat equivalent is aan tweemal de waarde van het krachtens de Wet op de Sociale Zekerheid vastgestelde basisbedrag, mits de netto watarde van de te verdelen goederen zulks toelaat. ${ }^{255}$ In 1998 bedroeg dit basisbedrag 36.400 Kronen (4.071,58 Euro); het "beschermd bedrag" dat aan de overlevende partner zou worden toegekend zou dan 8.000 Euro bedragen. Om een voorbeeld te geven, als Sim en Sam ten tijde van het overlijden van Sim gezamenlijke huishoudelijke goederen ter waarde van 10.000 Euro hebben, heeft Sam bij de verdeling van bet gezamenlijke vermogen recht op 8.000 Euro (tweemaal het door de Wet op de Sociale Zekerheid vastgesteld bedrag), en komen aan de nalatenschap van Sim goederen ter waarde van 2.000 Euro ten goede (of een geldbedrag tot een maximum van 2.000 Euro, als Sam die goederen zou willen overmomen). Als de retatio zou zujn beëindigd doordat de partners uit elkaur zouden zijn gegaan, zou Sam slechts recht hebben gehad op de helft van de boedel (5.000 Euro). De overlevende partner heeft deze speciale rechten niet indien hij of zij onwardig is on te erven. Een soortgelijle regeling in Nederland zou uitkonst kunnen bieden in cen situatie als die in de zaak Smit-Brumsma, waar beide partners eigen inkonsten hadden en dus in principe zelfstandig waren, mar waar de dood van de ene partner tot verstoring van de financiele basis van de overlevende partner leidde. De invoering van een soortgelijke regelling strekt tot aanbeveling. Als, echter, het systeem van gelijke verdeling, zonder de speciale extra rechten in geval van overlijden, zou worden ingevoerd, zal er minder behoefte bestaan aan een erfrechtelijke regeling, omdat de verdeling in veel situaties tot gevolg zall hebben dat de overlevende partner zelfstandig zal zijin.

254 Wet Samentronenden (Gezamenlijke Woning), art. 5, twede zim.

255. 1962:381. 
Wk meen dat deze regeling in Nederland zou kunnen worden overgenomen. Maar ik aarzel een oplossing voor te stellen voor de situatie van de langdurige verzorgingsbehoeftige overlevende partner. Ik erken de behoette, maar zie op dit moment niet in hoe hieraan tegemoet kan worden gekomen. Het zou in theorie mogelijk zijn om het Zweedse model toe te passen, gekoppeld aan een speciale voorziening voor verzorgingshehoeftige overlevende partners, waarbij woorzien wordt in een hoger toe te kennen bedrag. Maar hoe hoog zou dit bedrag moeten zijn? Alleen al het stellen van deze vraag doet vermoeden dat dit geen goede oplossing is. Een mogelijk alternatief is te vinden in de regeling die sinds 1938 in Engeland van toepassing is. Daar heef de rechter de bevoegdheid on op verzoek aan de overlevende partner die gedurende de periode van twee jaar die aan het overlijien vooratging met de overledene heeft samengewoond als waren zij gehuwd, een deel van de erfenis toe te kennen. ${ }^{256}$ De uitoefening van deze bevoegdheid is echter niet zonder problemen, nog daargelaten de vraag of een soortgelijke bevoegdheid wel in het Nederlandse erfiecht is in te passen. In het ontwerp BW van Eritrea is ook een bepaling met betrekking tot thet erfrecht opgenomen. Op grond wan artikel 710 van Boek 1 heeft de rechter in- $^{2}$ dien de samenwoners langdurig als man en vrouw hebben samengewoond en de relatie door de dood is beëindigd, de bevoegdheid te bevelen dat de overtevende samenwoner dezelfde erfrechten zal hebben als een echtgenoot. De rechter kan hier alleen toe overgaan indien zulks in het licht van alle omstandigheden redelijk is. ${ }^{257} \mathrm{Ik}$ will hier echter niet ingaan op de voor-en nadelen wan de Engelse, de Eritrese of een andere erfrechtelijke regeling voor samenwoners. Het gaat hierbij in de eerste plaats niet, zoals hiervoor, om vorderingen tussen de samenwonende partners onderling, matar om de erfrechtelijke vraag hoe de vordering van de overlevende verzorgingsbehoeftige partner zich zou moeten verhouden tot de rechten van de wettelijke erfgenamen, de echtgenoot van de erflater en van de begunstigden krachtens testamentaire beschikkingen van de erflater. Deze materie wil ik bij een andere gelegenheid aan de orde stellen.

\section{Een dreigement voor het huwelijk?}

Fen argument tégen alle oplossingen die hiervoor zijin besproken en voór de huidige afwezigheid van een privaatrechtelijke regeling in Nederland, is dat een regeling van de positie van ongehuwden het ongehuwd samenleven te aantrekkelijk zou kumen maken. De regeling zou paren aanleiding kunnen geven on niet te huwen, terwijl $z j$ dit anders wellicht wel gedaan zouden hebben. Daarbij moet wel bedacht worden dat Nederland het geregistreerd partnerschap heef ingevoerd, waardoor paren wan verschillend geslacht reeds nu kumnen kiezen tussen huwen of registreren. Marar misschien wordt het als minder bezwaarlik ervaren dat een paar voor geregistreerd partnerschap kiest dan dat het van het treffen van een regeling in het geheel afziet.

Het is dan ook interessant te bezien welke ervaringen in dit verband in $Z$ weden met het invoeren van de Wet Samenwonenden (Gezamenligke Woning) zijn op-

256 Inheritance (Prowision for Family and Dependants) Act 1975, as anended by Law Reform (Succession Act 1995.

25: Ontwerp BW van Eritrea.;

(1) If wo persons howe liwed together for a long wine as if they were wawlad and the relationship is

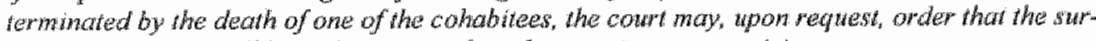

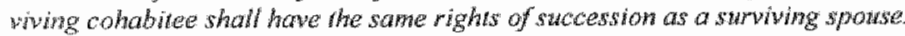


gedaun. De navolgende cifers betreffen het ammal vrowwen die voor de eerste keer trouwen, in adutallen per 1000 mwoners. 258

$\begin{array}{ll}1977 & 76 \\ 1983 & 52 \\ 1987 & 49 \\ 1993 & 38 \\ 1996 & 33\end{array}$

De Wet Samenwonenden werd in 1988 wan kracht. In vergelijking met 1987 is het aantal huwelijken gedald. Maar is deze daling veroorzakt door de Wet Samenwohenden of is $z$ ij slechts te beschouwen alls een element van een breder proces van verandering? Opmerkellijk is in ieder geval dat reeds de aan de inwerkingtreding van de Wet Samenwonenden voorafgaande periode van 1977 tot 1987 een forse daling wan het antal huwelijken te zien gaf. Of de wet als zodanig veel invloed op het gedrag van mensen heef valt voonts te betwijfelen, nu, zoals eerder is aangegeven, aanstaande partners doorgaans matig tot slecht op de hoogte zijn van de juridische consequenties van hel huwen of het afzien hiervan. Voor de Zweedse Commissie die zich heeft gebogen over de werking van de Wet Samenwoning was dit in heder geval aanleiding on het geven van meer bekendheid aan de wet als een van de actiepunten op te nemen. Ook dient te worden opgemerkt dat Zweden niet het enige land is met een dalend huwelijkspercentage. Andere landen, als Denemarken, Finland en Frankvijk kennen dit fenomeen ook, terwijl deze landen geen wettelijke regeling voor samenwonenden kennen. Hoewel er in $Z$ weden zeker zorgen bestaan over het effect van de Wet Samenwonenden op de trouw/ustigheid van de bevolking, is er geen bewijg dat deze gegrond zijn.

\section{Slot}

lk heb in deze rede in wezen maar een heel klein deel van een veel groter probleem aangesneden. Zo ben ik bijwoorbeeld niet ingegaan op de problemen die zich in het publiekrecht met betrekking tot samenwonenden voordoen, maar heb ik mij beperkt tot het privaatrecht en dan nog alleen tot de relaties die als informele huwelijken kumnen worden aangemerkt.

Wettelijk handelen om de verhouding tussen samenwoners privaatrechtelijk to regeten lijkt geboden. Uit de demografische gegevens blijkt dat steeds meer mensen voor een steeds een langer deel wan hun leven ongehuwd samenwonen. Uil de rechtsprakk met betrekking tot de problemen die samenhangen met de beẽindiging wan deze relaties blikt dat de huidige wettelijke regeling in een aantal opzichten tekort schiet. De afwezigheid wan ween wellike regeling wan het samenwonen is geba seerd op de veronderstelling dat samenwonenden bewust van het huwelijk hebben afgezien en om die reden geen nadere regeling van hun relatie wensen. Zij zouden woor "relatievrijheid" hebben gekozen. Het initiatief om een (notariele) regeling te treffen zou bij de partners zelf moeten liggen.

In de praktijk is echter gebleken dat zich veel problemen voordoen met betrekking tot de verdeling van de goederen. Er is voorts geen mogelijkheid om schulden te verdelen als de partners hierover niets hebben afgesproken. Verder heef de buidige wettelijke regeling tot gevolg dat de verdeling van de goederen in veel ge-

${ }^{25}$ Statistiska centralbyri: A. Agell, Aknewskap, samboende och parmershap, 2nd Ed., lustus forllag, Uppsalia, 1998; Agell, a.w. 14. 61, pp. 210-211. 
vallen geen goede afspiegeling is van de bijdrage van elk der parthers an het verwerven, het behoud en de verbetering wan de gewamenlike goederen.

Aan de huidige juridische benadering van de regeling val de goederen wan samenwonenden ligt een bepaalde veronderstelling over de aard van de samenwoningsrelatie en de darmee door de partners beoogde doelen ten grondslag. On deze veronderstelling op haar validiteit te toetsen is sociologisch onderzoek verhelderend. Dan blikt dat samenwoners vaak maar een zeer vaag besef hebben van de juridische consequenties van de relatievorm waarwoor zij hebben gekozen. Sociologisch onderzoek wijst bovendien uit dat de veronderstelling dat de samenwoningsrelatie zich vooral kenmerkt door vrijblijwendheid, op drijfzand berust. Uit het onderzoek van Van der Avort wloeit immers voort dat samenwoners zich veeleer bezig houden met een proces van onderhandeling, waarbij de parners ernaar streven om een wenwicht te vinden tussen individualiteit en gemeenschappelijkheid. Dit gegeven zou ook juridische consequenties moeten hebben.

De huidige juridische benadering van het samenwonen is, kortom, te simpel. De afwijzing van het huwelijk wordt gezien als een argument om wan negeling af te zien. Maar tussen howelijk en helemaal niets ligt, zoals onder meer uit de rechtsvergelij. king blijkt, een scalla van mogelijkheden. In beperkte mate is de erkenning van een tussenvorm reeds aanwezig in het Nederlands recht. Het moet alleen een beetje theer. Ik heb hiertoe een wettelijke tussenvorm voorgesteld, waarbij ik me sterk heb laten inspireten door de Zweedse Wet Samenwonenden (Gezamenlijk Huis).

\section{Nu kom ik aan het sllot van mijn verhaal.}

Ik dank het College van Bestuur, het bestuur van de Faculteit der Rechtsgeleercheid, de Stichting Wetenschapsbeoefening en alle anderen die aan de totstandkoming van deze leerstoel hebben meegewerkt, voor het in mij gestelde vertrouwen. Ik wens het College van Bestuur geluk met zijn keuze om het familierecht door middel wan deze bijzondere leerstoel te ondersteunen. Familierecht is een zeer bijzonder vak. Het is niet zomaar een onderdeel van het priwaatrecht. Zo kenmerkt het familierecht zich veel meer dan welk vak ook door een interdisciplinaire aampak. Ik geloof dat mijn rede de waarde van een interdisciplinaire aanpak illustreert. In het promotieonderzoek van Catelijne Leenen over de positie van de minderjarige als patiënt, dat «k samen met professor Frans van Wijmen zal begeleiden, is eveneens sprake van samenwerking tussen drie verschillende faculteiten van deze universiteit, te weten de faculteiten der rechtsgeleerdheid, geneeskunde en gezondheidsrecht.

Het familierecht is ook sterk verweven met de rechten van de mens. Ihist dit rakwlak tussen familierecht en mensentechten spreekt mij zeer aan en zal mmer mijn achdacht blijwen veagen. Sinds 1993 heb ik met enige regelmat woor het NJCM-Bulletin geschreven. Verder vindt mijn onderzoek nat de regeling van verschillende familievormen plats onder de hoede wan het Centrum voor de Rechten van de Mens. Op internationaal niveau kan het familierecht zich overigens in speciale aandacht verheugen: zo komt het woor in veel onderzoeksprogramma's wan de Europese Unie en geniet het de speciale aandacht van de Raad van Europa.

Familierecht onderscheidt zich nog in een ander opzicht van het algemene privaatrecht. De veranderingen die zich de laatste decennia in de samenlleving als geheel en het gezin in het bijzonder hebben voltrokken, hebben een onophoudelijke stroom van familierechtelijke wetgeving in gang gezet. Het is een formidabele taak om dit allemaal bij te houden. Het gaat ook niet zo maar on marginale aanpassingen, mar on fundamentele veranderingen die het gevolg zijn van maatschappelijke verschuivingen. IK noem de wetswoorstellen over de openstelling van het huwelijk voor 
partners van gelijk geslacht en andere wetswoorstellen die de rechtspositie van kinderen die uit dergelijke relaties worden geboren regelen. Deze veranderingen zijn geen incidenten. In 1998 zijn, na een zeer uitgebreide discussie, newwe wetten ingevoerd die het geregistreerd partnerschap, het ontstaan van ouderschap en het gezag over de kinderen regelen. Dan heb ik het nog niet gehad over de weigeving op het gebied van de kinderbescherming of de voorgestelde wijzigingen ten aanzien van de rechten en plichten van echtgenoten.

Studenten zijn zich ervan bewust dat familierecht een belangrijk vak is; onmislbaar voor notarissen en bread and butter voor advocaten. Daarom kiezen in Maastricht per jaar ongeveer zeventig studenten voor het wak personen- en familierecht, tachtig voor jeugdrecht en tussen de tien en twintig voor het meer gespecialisecrde vak Europees Familierecht. lk ben van plan om dit aanbod, samen met mijn collega"s Catelijne Leenen, Solange Daenen en Ton Gehlen verder te verbeteren en uit te breiden.

U zult mij verwijten dat ik nog niet weel over het Europees Familierecht heb gezegd, terwijl deze leerstoel nu juist daarop gericht is. In éen opzicht is het oormerk 'Europees' overbodig. Een belangrijk deel van Europees Familierecht bestaat uit internationalrechtelijke bepalingen. ledere Nederlandse jurist zou immers op de hoogte moeten zijn van de doorwerking van die verdragsbepalingen in het nationale recht. Zo bezien is iedere familierechtelijke jurist ook een Europeesfamilierechtelijke jurist. Maar Europees familierecht gaat verder. Het heeft als belangrijkste functie het maken van vergelijkingen met andere stelsels, zoals ik dat met deze rede heb beoogd te illustreren.

Het spreekt niet voor zichzelf dat een Engelse vrouw in het land belandt dat wordt beheerst door het poldermodel en waar de muskusrat als staatsvijand nummer 1 gelct, en dat uitgerekend zij het lef heeft om iets over het Nederlandse recht te vertellen. Dit verschijnsel vraagt om een verklaring. Dat het opmerkelijke hieraan doorgazns niet opvalt hangt samen met de openheid en tolerantie en met de - geloof ik - onweerstaanbare nieuwsgierigheid naar het vreemde die ik hier aan de rechtenfaculteit, en dan met name in de capaciteitsgroep privaatrecht, heb aangetroffen. In 1991 solliciteerde ik naar de positie van tniversitaire docente. Ik bood aan het goederenrecht te doceren. I $k$ wist toen weliswaar helemaal niets over het Nederlandse recht, maar dat heeft de benoemingscommissie er niet van weerhouden om de lieuze op mij te laten vallen. Gerard-Rene de Groot heeft mij zelfs mijn eerste boek over het Nedertandse recht gegeven: een burgerlijk wetboek met omzetting van de oude in de nieuwe bepalingen. In Nederland heb ik mij kunnen ontplooien op een manier die, geloof ik, in Engeland niet mogelijk zou zijn geweest.

Drie mensen hebben in het bijzonder aan deze ontplooiling bijgedragen. De eerst twee zijn mijn twee promotores, Aalt Willem Heringa en Jan de Boer, die op deze dag recht zit te spreken op het verre Sint Marten. Zij vornden de ideale ondersteuning voor mijn ontdekkingsreis op het raakvlak tussen de rechten van de mens en het familierecht. Beiden hebben ze mij tot voorbeeld gestrekt als bescheiden, uitstekende wetenschappers die zeer veel over hebben voor hun studenten en jongere medewerkers. De derde persoon die een belangrijke bijdrage heeft geleverd - de belangrijkste - is mijn echtgenoot, Rob Bakker. Hij heeft mij naar Nederland gelokt en mij ervan overtuigd dat cle rechtspraak van de Hoge Raad minstens zo interessant is voor mijn onderzoek als de uitspraken van het Bundesverfassungsgericht. Hij heeft mij aan Aalt Willem Heringa voorgesteld. En hij heeft mij wegwijs gemaakt in de mysteries van de Nederlandse samenlewing, van het poldermodel tot de muskusrat, en in veel andere zaken waarvan $i k$, toen ik hier kwam, niet veel kaas had gegeten. 
Hij heef al mijn Nederlandstalige stukken gelezen en hieruit de fouten gehald die men maakt als men in een vreemde taal schrijft en waarvan het zo moeilijk is af te komen.

Ik wil mijn bewondering uiten voor en nijn dank uitspreken aan vier vrouwen - Margriet, Ine, Peggy en Pia - die met intelligentie, stijl, vriendelijkheid en ook met een zekere strengheid de capaciteitsgroep privaatrecht bijstaan en tot op zekere hoogte, op de manier van Yes Minister, de capaciteitsgroep ook besturen. Zij vooral, maken het tot een genoegen om bij de capaciteitsgroep privaatrecht te werken.

Ik wil u allen bedanken voor uw aanwezigheid hier vandaag, in het bijzonder mijn vader, Michael Forder, die uit Zuid-West Engeland is overgekomen, en alle vrienden die uit het polderland zijn gekomem.

In het Engels wordt gezegd: "It's nice to be important, but it's more important to be nice.' $1 \mathrm{k}$ prijs mij gelukkig dat ik hier erg veel vrienden heb gemaakt, te veel om hier ieder afzonderlijk te bedanken. Er zijn weel mensen die mij op belangrijke momenten hebben geholpen. Ik wil op deze dag een woord van dank uitspreken aan dr. Resie Moonen en Margo van der Molen die mij beiden op zeer bijzondere manier hebben bijgestaan. Zonder al die wrienden - zonder Rob en onze twee geweldige kinderen Luke en Anouk - zou ik hier niet hebben gestaan.

Tk heb gezegd. 


\section{Literaturunijst}

Agetl, A. (1981), 'Samenwonen zonder huwelijk, ideologie, inlhoud en gevolgen valt het wethelijk beleid in Zweden", finl: Santenleven in meervoud, pp. 192.214.

Avort, A.J.P.M. wan der (1987), De galzige vrij-blivendhe id wan explicietz relates, Tilburg University Press 1987.

Bailey, M. (1998), Law Commixsion of Camada Contract (Personal Relationships), Otawa, 1998.

Barlow, A., Lind, C. (1999), "A matter of trust: the allocation of rights in the family home", Legral Studies 1999 Vol. 19 No. 4, pp. $468-488$.

Boer, J. de, (1998), Mr C. Asser's tot de beoefening van het Nederlands burgerlijk recht, Personen en familierecht, Tjeerk Willink, Devemter, 1998.

Binuberg, G.G. (1981) 'Cohabitation without marriage: a different perspective' ${ }_{\text {( }}$ (1981) 28 U.C.L.A.Rev. 1125

Burght, Gr. van der, (1982), "Enige opnerkingen over de vermogensrechtelijke gevolgen van het ongehuwd samenteven", in: Wer en rech buten echt, pp. $31-60$.

Burght, Grt, van der, (1983). "Het vermogensrechtelijke minimum als titgangspunt als persothen galan samenwonen", in: Relatiewiyeid en recht, pp. 88-94.

Burght, Gr. van der, (1999) 'De thushoudelijke echtgenoot behoort bij echtscheiding niet zonder enige vergoeding voor de verrichte arbeid achter te blijwen" in: WPFA Milleniumbumdel, pp. 27.35 .

Commissie alimentatienomen rappor: (1978), 7 mart 1978.

Cuyvers, P.F., Latten, J.J. (1994), Relatie en Gezinsworming in de jaren negentig. CBS/Nederlandse gezinsraad, Voorburg/Heerlen.

Davids, W.J.M. (1983) 'Alimentatie, niet in de lengte, wel in de breedte", in: Henriquezbutel, pp. $77-85$.

Deech, $\mathbb{R}$. (1980), "The case againgt legal recognition of cohabitation', (1980) I.C.L.Q. 480 .

Duijvendijk-Brand, J. van, 'Naar een nieuw huwelijksvermogensrecht?', verslag van destudiedag Vereniging FJR en KNB 21 januari 1998, Ars Notariatus XCHI, Deventer, Kluwer, $\mathrm{P}$. 25 a.vi:

Duijwendijk-Brand, J, van, Afrekenen buj (echy)scheiding, Deventer, Kuwer, 1990.

Estaugh, V., Kiernan, K.E. (1993), 'Cohabitation: Extra-marital child-bearing and social policy', Family Policy Studies Centre, Oecasional Paper 17.

Giendon, M.A. (1981), "Het moderne huwelijksrecht en zijn impliciete veronderstellingen", in: Samenleven in meervoud, pp. 50.69.

Gouriet, M. (1999), "Claims by cohabitants, capital and maintenance rights with reference to legislation in other jurisdictions", Solicitors Family Law Assaciation Review, June 1999, pp. $25-28$

Hartkamp. A.S, Snijders, W. (1983), "Het nienwe BW en de ongehuwd samenwonenden", in: Nenriquez-bundel, pp. 135-153.

Haskey, $J$. (1995), "Trends in tharriage and cohabitation: the decline in marriage and the changing patten of living in partnerships" Population Trends Vol, 80, 1995.

Heiden, A.M. wan der, Robent, W.C.J., Straver, C.J. (1980), Twee relaties, anders daw het hwwelife? Samson sociale en culturele reeks, Alphen aan den Rijn/Brussel.

Heiden, A.M. van der, Straver, C.J., Vhet, R.W.F van der (1994), De Huwelijkse logica, Huwelijkmodel en inrichting wan het samenleven bij ajbetders en anderen, NISSO, DSWO Press, Rijksuniversiteit Leiden.

Henriquez, E. Cohen, (1974), "Vermogensrechtelijke gevolgen van altematieve samenlevingsvormen', int NJB boekenreeks. 1, Twee mensen en het rechi, Tjeenk Willink, Zwolle, pp. $42-59$.

Hentiquez, E. Cohen, Molmaker, J.K. (1977), Priwaatrechelijke en fiscale aspecten wan samenlevingswormen buitew hawelijk, Pre-adviezen Koninklifhe Notatiele Broederschap, Kluwer, Deventer.

Henriquez, E. Cohen, (1983) "Regels var samenlevingsovereenkomst", in: Relatievrijheid en rech, pp. 94. 101 . 


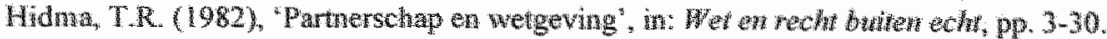

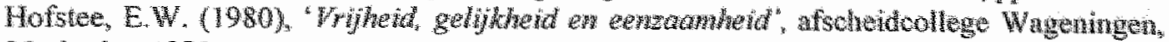
30 oktober 1980.

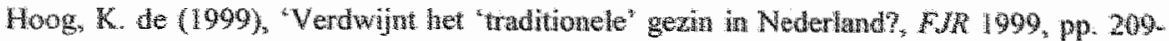
213.

Lekkerkerker, G.J.C. (1999), "Het sarrenlevingscontract, who ordenende functie in privanrechtelinke zin", WPNR 6364 .

long, A.H. de (1997), "Nationale huishowders prognose 1996 : steeds winder partin zing gehuwd", Maandstatistiek wan de bevolking, $(1997) 5(18-28)$.

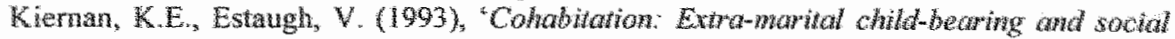
policy" Famly Policy Stwdies Centre, Occasional Paper 17.

Kienan. K.E. (1999), "Cohabitation in Western Europe", Population Trends (Office for National Statistics) 96 , summer 1999, pp. $25-32$.

Kooy, G.A. (1997), Gezinsleven en recht in noorlogs Nederland, $R$ M 7 hemis $1997 \mathrm{jg}$. 158, pp. $123-129$.

Lampe, P.P. (1975), 'Alimentatie en concubinate, NIB 1975, pp. 1163-1168.

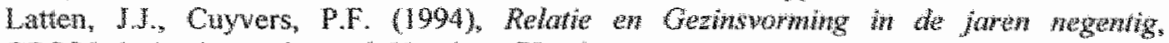
CESNedenlandse gezinsrad, voorburg/Heerten.

Lind, C., Barlow, A. (1999), "A matter of must the allocation of rights in the family home". Legal Stwdies 1999 Vol. 19 No. 4, pp. $468-488$.

Luijten, E.A.A. (1983), 'De erfrechtelijke positie van de langstlevende echtgenoot en die van de overtevende partner in butenhweligkse relaties; in: Relatievithetd en rech, pp. $145-158$

Lyon, T. (1980), "Towards a justification of property rights for cohnbitees", (1980) 130 New" Low Nowrial 228.

Manting, D. (1994), "Meer scheidingen dan echscheidingea", Maanditaristek wan de bewolking CBS, jirg. 42, 1994-4.

Minkenhof, A.A.L. (1983), "Enkele betwistbare stellingen ter anmering van de discussie", in Relatievrijheiden rechi, pp. 119.137.

Molmaker, J.K., Henriquez, E. Cohen (1997). Priwatrechtelike en fiscale aspectem wam samenlewingswormen buiten hwelijk. Pre-adviezen Roninklijke Notorièle Broederschop, Kinwer, Deventer.

Molmaker, J.K. (1978), 'De erfrechtelijke en successierechtelike aspecten van het SamenLeven", in: Samen-Lewen, pp. 53-61.

Mourik, M.J.A. van (1978), "Partif-autonomie en wetgeving", in: Samen-Leven, pp. 63-72.

Neleman, $P$. (1983), 'De positie van de huishoudelijke partij', in: Relatievrijheld en pecht, pp. $128-137$.

Nota, I.A. (1974), "Gewoon samenleven?", in: Twee mensen en het recht, pp. 60-65.

Oliver, D. (1982), "Why do people live together?" Jout wal of Social Welfone Law 1982, pp. 209-222.

Pickford, R. (1999), Fathers, marriage and the law, London, FPSC/Joseph Rowntree froun dation.

Rechuis, W.H.M., Slob, E.E., (1991) Invouring boeken 3,5 en 6, Aanpassing Burgerijk Wetboek, Kluwer, Deventer.

Robert, W.C.J., Heiden, A.M. van der, Straver, C.J. (1980), Twee relories, anders don her huwelijk?, Samson sociale en culturele reeks, Alphen axth den Rijn/Brussel.

Rogers, H. (1999), "Cohabitation committee report to the National Committee", Solicitors Family Law Association Review, June 1999, pp. 5-12.

Ruiter, I. de (1977), "Veranderingen in familie- en gezinsrecht", Préwdviezen jaanwergadering 1977 Vereniging voor Familie-en jeugdroch, Tjeenk Willink, Zwolle.

Scherf, Y. (1999), Registered Partiership in the Nenterlands, A Quick Scan, WODC, Rijswijk, 1999.

Scottish Law Commission (1992), Repart on Fantily Law No. 135, H.M.S. Edinburgh. 1992. 
Senaeve. P. (1998), "De wethelike samerwoning en het geregistreerd partnerschap in het Belgusch recht', Tijdschwift woor her fawilierech 1998, pp. 254-259.

Simonis, J. (1999)(Ed.), "High dworce rates: the state of evidence on reasons and remedies", Lord Chancellor"s Department Research Series, 2/1999, Vol. I, London, LCD, 1999.

Slob, E.E., Reehuis, W.H.M. (199l) Inwoering boeken 3,5 en 6, Aanpassing Burgerlijk Wetboek, Kluwer, Deventer.

Simart, C., Stevens, P. (2000), Cohatbitanion breakdown, Family \& Parenthood, Policy and Practice, Family Policy Studies Centre, Joseph Rowntree Foundation, London, 2000.

Snijders, W., Hartkamp, A.S.(1983), "Het nieuwe BW en de ongehuwd samenwonenden", in: Heviquez-bundel, pp. 135-153.

Sociall en culureel planburean (1998). Sociaal en cultureel rapport 1998, 25 jaar sociale verandering, Riswipk, septemiber 1998.

Stevens, P., Smatt, C. (2000), Cohabilation breakdown, Family \& Parenthood, Policy and Practice, Family Policy Studies Centre, Joseph Rowntree Foundation, London.

Straver, C.J., Heiden, A.M. van der, Robert, W.C.J. (1980), Twee relaties, anders don het hwwelijk?, Samson sociale en culturele reeks, Alphen aan den Rijn/Brussel.

Straver, C.J., Van der Heiden, A.M., Van der Vliet, R.W.F. (1994), De Huwelijhse logica, Howelijksmodel en inrichting van het samenteven bij arbeiders en anderen, NISSO, DSWO Press, Rijksuniversiteit Leiden.

Weitzman, L. J. (1981), The Marrigge Contract, A Gude to Living with Lovers and Spouses, The Free Press (New York) Collier Macmillan (London).

Weitzman, L. e.a. (1981a), "Contracten woor intieme relaties', in: Samenleven in meervoud, pp. $87-138$.

Wiel, A.M. van de (1976), "Alimentatie en concubinaat", NJB 1976, pp. 191-194.

Wortmann, S.F.M. (1999), Personen-en familierech, Kluwer, Deventer.

Wortmann, S.F.M.(1999), "Gevolgen wan de scheiding: voortduring van het gezamenlijk gezag en limitering van de alimentatie" in: VPFA Millenimbundel, pp. 49-58.

\section{Verzamelwerken}

Fiscaal en Notarieel Instituut, Rijksuniversiteit Leiden, Samen-Leven, Landelijk congres over de buitenhowalijkse relatie, Kliwwer, Deventer, 1978.

Henriquez-bundel, Samenleven, samenwerken, opstellen aangeboden aan prof $m$. E.C. Henriguez ter gelegenheid wan zijm wijfensestigste verjoardag, Kluwer, Deventer, 1983.

Nederlandse gezinsraad, Wet en recht buiten echt, Twee relaties met en zonder kinderen, Kinwer, Deventer, 1982.

NJB boekenreeks II, Thee mensen en het wech, Tjeenk Willink, Zwolle, 1974.

Robert, W.C.J., en Wanier, J.M.A. (red.) Relatiewilheid en recht, Kluwer, Deventer, 1983.

Saal, C.D., en Straver, C.l., (red.) Samewheven in meervoud, juridische en sociologische aspecten wan het samewwonen zonder huwelihk, Samson sociale en culturele reeks, Alphen aan de Rijn/Brussel, 1981.

VPFA Milleniumbundel, Het fonilierecht im het perspecticf van de $21^{\text {sto }}$ eeww, Kluwer, 1999. Waaijer, J.M.A., en Robert, W.C.J., (red.), Relatievwiheid en recht, Kluwer, Devenw ter, 1983. 